\title{
ATERRAMENTO DE ANTENAS DE TV EM EDIFICAÇÕES RESIDENCIAIS
}

Sanderson Queiroz de Lima - 02/50872 


\section{ATERRAMENTO DE ANTENAS DE TV EM EDIFICAÇÕES RESIDENCIAIS}

Por:

Sanderson Queiroz de Lima - 02/50872

ORIENTADOR

Prof. Alcides Leandro da Silva

Brasília, Julho de 2009 


\title{
ATERRAMENTO DE ANTENAS DE TV EM EDIFICAÇÕES RESIDENCIAIS
}

\author{
Por: \\ Sanderson Queiroz de Lima
}

Monografia submetida ao Departamento de Engenharia Elétrica da Faculdade de Tecnologia da Universidade de Brasília como parte dos requisitos necessários para a obtenção do grau de Engenheiro Eletricista

Banca Examinadora:

Prof. Alcides Leandro da Silva, Mestre (UnB)

(Orientador)

Prof. Francisco Damasceno Freitas, Doutor (UnB)

(Examinador Interno)

Prof. Franklin da Costa Silva, Doutor (UnB)

(Examinador Interno) 


\section{RESUMO}

Parte desse trabalho é mostrar os benefícios da equipotencialização e aterramento como forma de proteção às pessoas e equipamentos eletrônicos contra os efeitos das descargas atmosféricas indiretas.

Pela pesquisa, constatou-se que apesar de os efeitos oriundos por descargas atmosféricas diretas serem muito graves, a maioria dos prejuízos e acidentes envolvem descargas indiretas nas proximidades das residências. Em alguns casos, mesmo com a instalação de um Sistema de Proteção contra Descargas Atmosféricas (SPDA), danos severos a equipamentos eletrônicos não foram evitados.

Percebeu-se que apesar de haver uma preocupação no cumprimento, quando necessário, da norma NBR 5419/2005, que trata de proteção contra descargas atmosféricas, não há a mesma preocupação quanto à necessidade de proteção contra os efeitos das descargas indiretas. A importância da equipotencialização e aterramento, conforme a NBR 5410/2004 (Instalações Elétricas em Baixa Tensão), é muitas vezes negligenciada ou simplesmente desconhecida.

De acordo com a NBR 5419/2005, qualquer corpo metálico elevado acima da construção deve ser considerado, para fins de projeto, como captor natural. Assim, corpos metálicos, como antenas de TV, devem ser considerados como captor natural por estarem sujeitas aos efeitos de descargas atmosféricas. Esses corpos, como captores naturais, devem ser ligados ao restante do sistema de proteção, garantindo um caminho para a descarga à terra. Diretrizes essas constantemente negligenciadas ora por desconhecimento das normas, ora por motivo de custos.

A pesquisa revelou, também, que um projeto de aterramento e equipotencialização pode, além de proteger o interior da construção contra as descargas atmosféricas, prolongar a vida de equipamentos eletrônicos sensíveis minimizando interferências eletromagnéticas e melhorando o sinal de recepção de equipamentos de telecomunicações. 


\section{DEDICATÓRIA}

Dedico este trabalho a todos aqueles que de forma direta ou indireta tenham me ajudado a concretizar mais este objetivo.

Aos meus pais Sr. Edson Ferreira de Lima e Sra. Sara Queiroz de M. Lima que sempre me ampararam nos grandes momentos de dificuldades;

E ao meu irmão Weldson Queiroz de Lima e sua esposa Larissa Lima, que sempre se mostraram solícitos e compreensivos. 


\section{AGRADECIMENTOS}

Em primeiro lugar agradeço a Deus por ter me provido de saúde, determinação e sabedoria para superar todas as dificuldades durante a graduação;

Ao meu orientador professor Alcides Leandro da Silva, pela paciência, discussões e apoio durante todo o tempo que passamos juntos; seja como seu monitor em Instalações Elétricas e Eletricidade, seja como seu orientando no trabalho de fim de curso;

Aos membros da ENETEC - Empresa Junior, que reacenderam a chama do desejo de encontrar soluções aos problemas, enquanto trabalhávamos em equipe, nos projetos solicitados;

Aos meus colegas de faculdade, que compartilharam comigo das batalhas do saber, aos professores e funcionários do Departamento de Engenharia Elétrica por sua presteza e atenção;

Por fim, agradeço à Universidade de Brasília - UnB, por ter dado as condições necessárias para a realização deste curso. 


\section{SUMÁRIO}

1. INTRODUÇÃO .....................................................................................................1

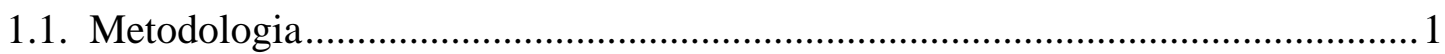

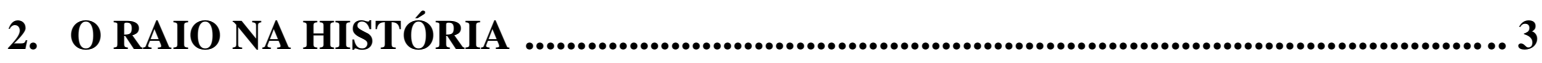

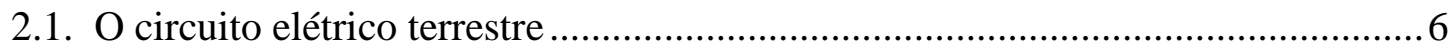

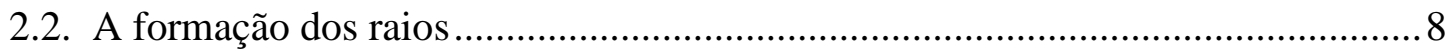

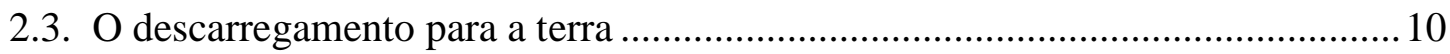

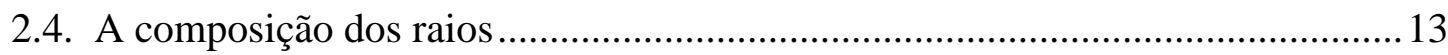

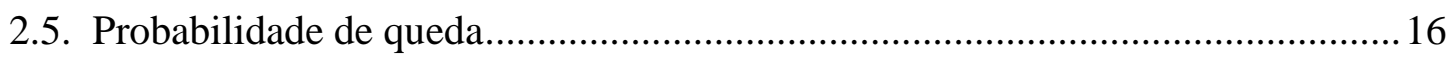

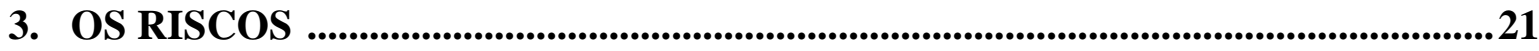

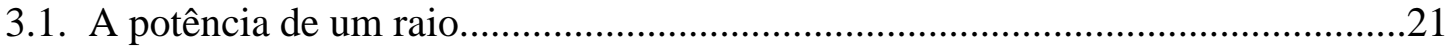

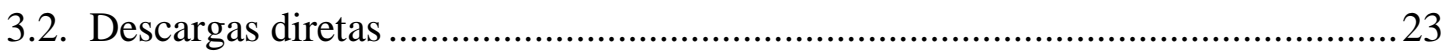

3.2.1. Situações de risco por exposição ……….........................................25

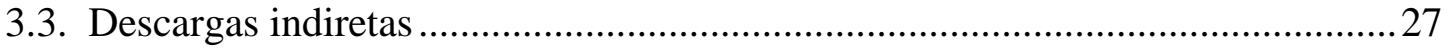

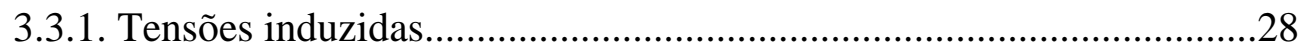

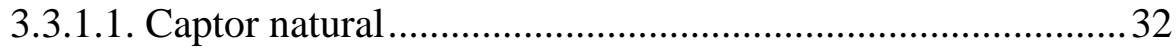

3.3.1.2. Os cabos de comunicação ................................................. 34

3.3.1.3. Outros efeitos causados por sobretensão ...............................36

3.3.2. Interferencia Eletromagnética (EMI) ............................................ 37

3.3.2.1. Fontes de EMI e sistemas de proteção .................................. 38

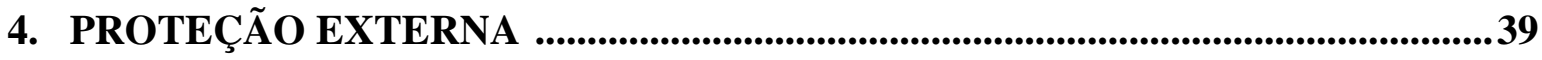

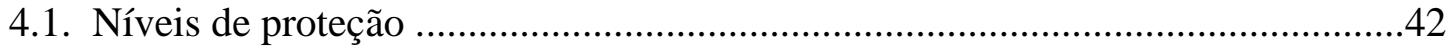

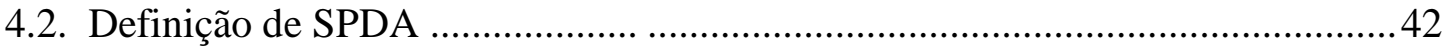

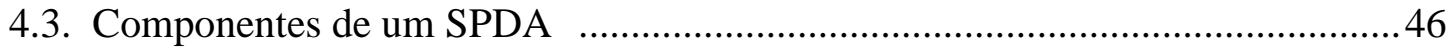

4.3.1. Subsistema de captores ...............................................................47

4.3.1.1. A filosofia "Franklin"......................................................... 48

4.3.1.2. A filosofia "Gaiola de Faraday"........................................ 51

4.3.1.3. O modelo eletrogeométrico ................................................ 53

4.3.1.4. O sistema híbrido .............................................................. 56

4.3.2. Cabos de descida ......................................................................... .57

4.4. Modelo de descarga de retorno ……............................................................ 58

4.5. Roteiro de um Projeto de Proteção .....................................................................62

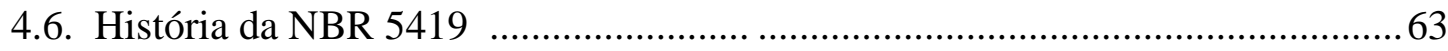




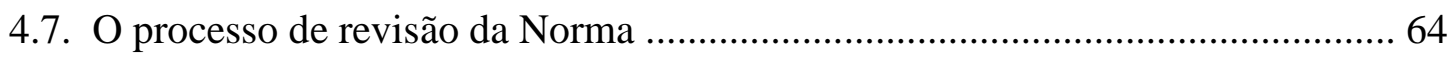

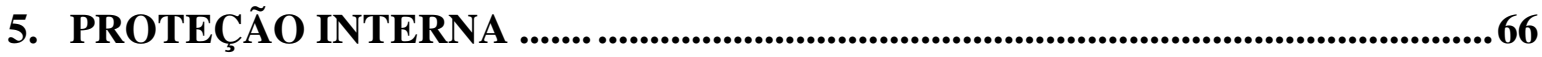

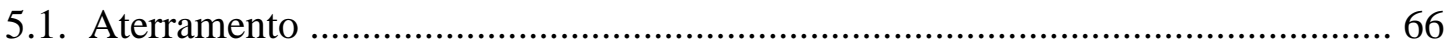

5.1.1. Resistência de aterramento .............................................................68

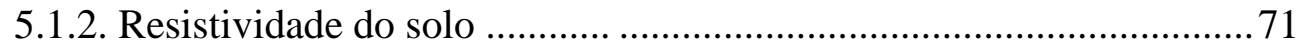

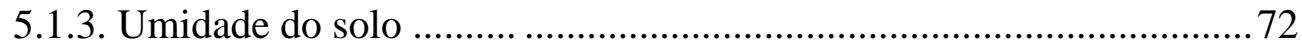

5.1.4. Concentração de sais ...................................................................... 73

5.1.5. Outros elementos do aterramento ................................................. 74

5.1.5.1. Condutores de aterramento ............................................ 76

5.1.5.2. Terminal de aterramento principal .....................................77

5.1.5.3. Condutores de proteção ..................................................... 77

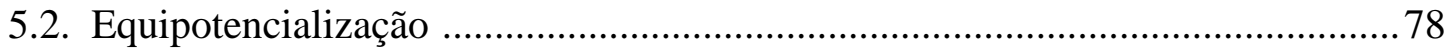

5.2.1. Sobretensões geradas por descargas atmosféricas …........................80

5.2.2. Equipamentos Eletrônicos Sensíveis .............................................. 81

5.2.3. Malha interna de equipotencialização .............................................. 82

5.2.4. Ligação equipotencial ..................................................................... 83

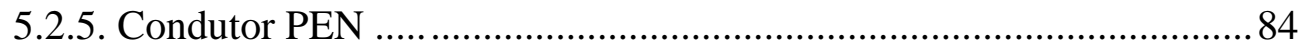

5.3. Compatibilidade Eletromagnética................................................................... 85

5.4. Qualidade de energia elétrica (QEE) ……................................................. 85

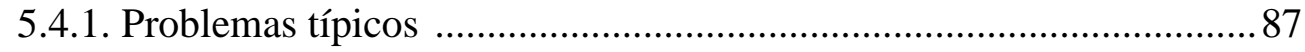

5.4.2. Aterramento para sinal de referência ............................................... 89

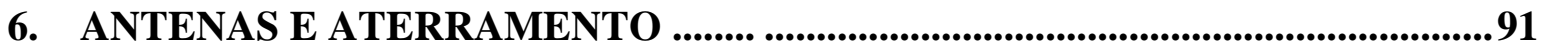

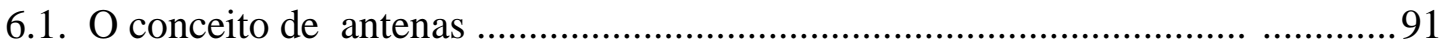

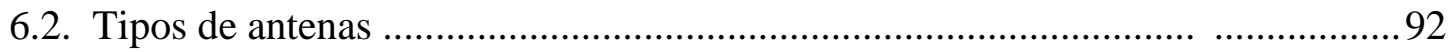

6.2.1. Antenas Yagi-Uda .......................................................................... 94

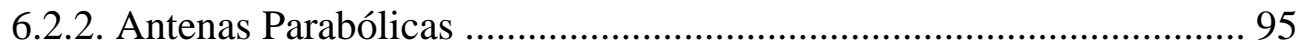

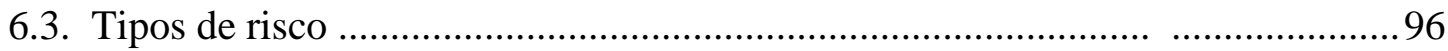

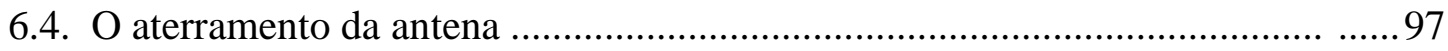

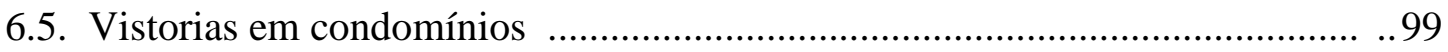

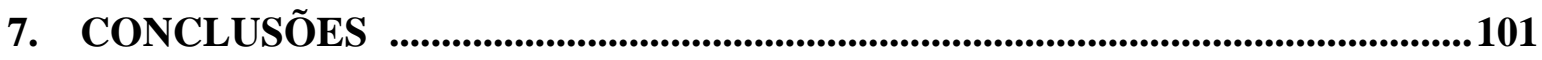

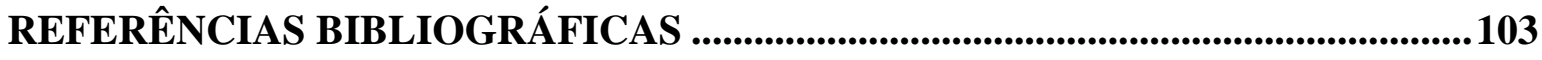




\section{LISTA DE FIGURAS}

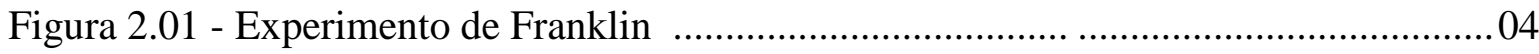

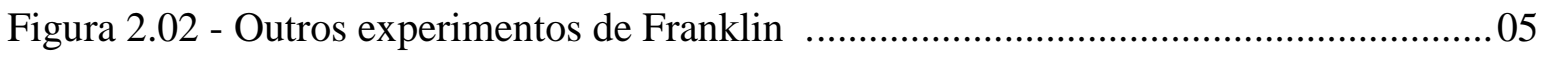

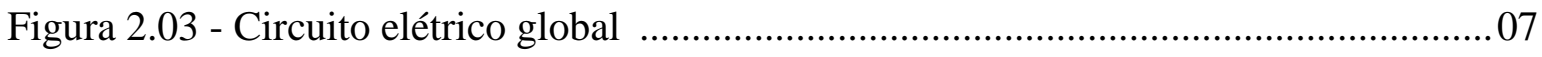

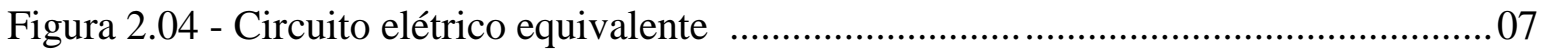

Figura 2.05 - Estação fixa para medição de corrente de descarga ......................................08

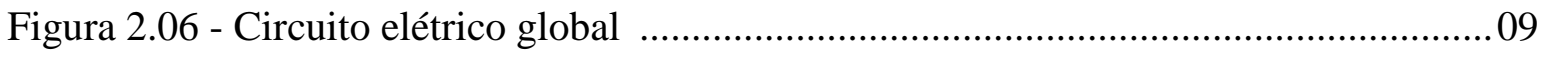

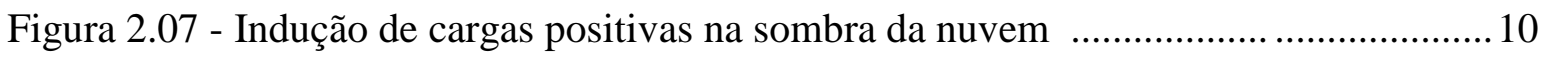

Figura 2.08 - Processo de descarga nuvem-solo ........................................................ 12

Figura 2.09 - Tipos de descarga nuvem-solo ............................................................... 13

Figura 2.10 - Sistema de localização otimizado ............................................................ 14

Figura 2.11 - Área de cobertura do RINDAT ............................................................. 15

Figura 2.12 - Mapa ceráunico coberto pelo RINDAT ................................................... 16

Figura 2.13 - Área de cobertura de um paralelepipezóide ............................................ 18

Figura 3.01 - Forma da onda de um raio ................................................................ 21

Figura 3.02 - Descarga para multiplos pontos ...................................................... 24

Figura 3.03 - Registro de uma descarga direta sobre uma árvore ...............................25

Figura 3.04 - Onda de sobretensão devido a descarga direta sobre LT .. ...........................27

Figura 3.05 - Onda eletromagnética irradiada pela corrente de retorno ...........................28

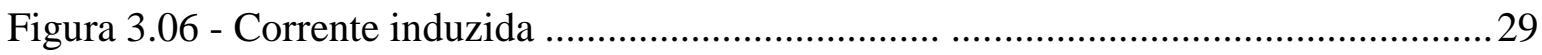

Figura 3.07 - Placa de PABX queimado após descarga sobre antena não aterrada .... ........ 31

Figura 3.08 - Placa de PABX queimado após descarga sobre antena não aterrada ............ 31

Figura 3.09 - Formas de incidência de tensão induzida .............................................. 33

Figura 3.10 - Tensão sobre um cabo coaxial .. ....................................................... 34

Figura 3.11 - Blindagem de um cabo coaxial ........................................................... 35

Figura 4.01 - Falibilidade dos sistemas de proteção ...................................................... 44 
Figura 4.02 - Configuração de um SPDA tipo Franklin

Figura 4.03 - Configuração de um SPDA tipo Gaiola de Faraday ...................................52

Figura 4.04 - Representação esquemática de aplicação do EGM.......................................54

Figura 4.05 - Efeito da amplitude de corrente na blindagem de linha . ..............................55

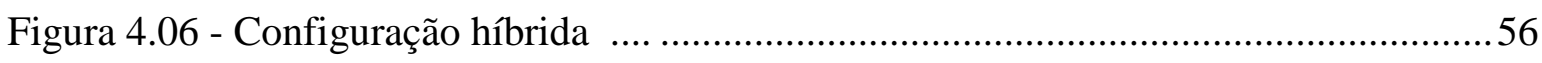

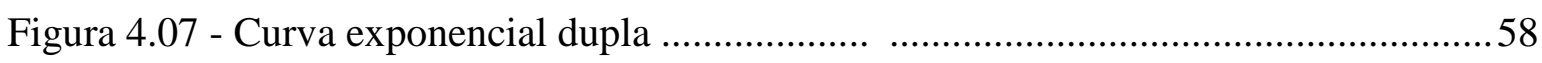

Figura 4.08 - Curva de Heidler......... ....................................................................... 59

Figura 4.09 - Simulação da função de Heidler......... ................................................... 61

Figura 5.01 - Cálculo do valor da resistência de aterramento .........................................69

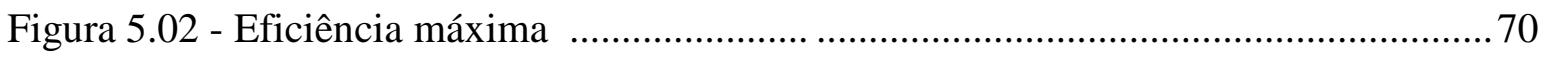

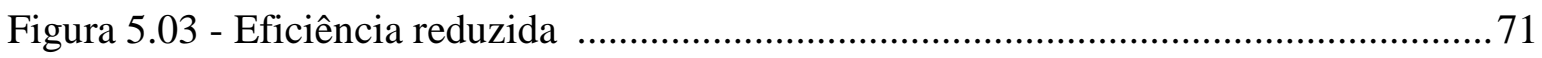

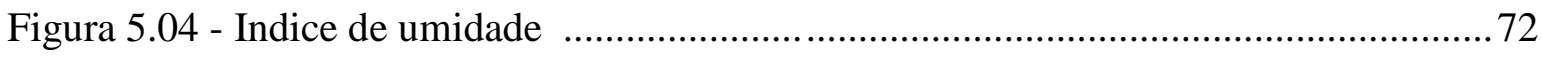

Figura 5.05 - Efeito do tipo de concentração de sais ......................................................... 74

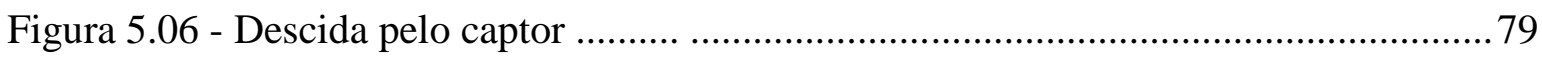

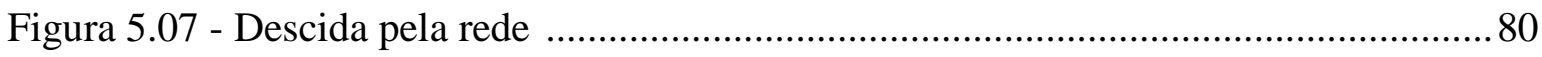

Figura 5.08 - Elevação de potencial ......................................................................... 81

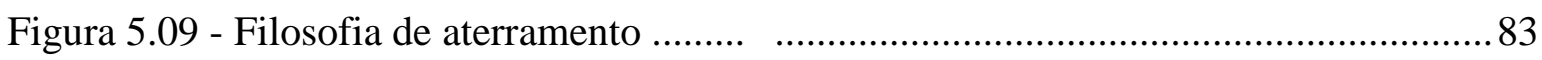

Figura 5.10 - Barra de equipotencialização ......................................................... 83

Figura 5.11 - Vista geral de um sistema de equalização em malha densa........................90

Figura 6.01 - Padrões de irradiação das antenas ............................................................ 93

Figura 6.02 - Exemplo de antena Yagi-Uda ............................................................... 94

Figura 6.03 - Exemplo de antena parabólica .......................................................... 95

Figura 6.04 - Mastro da antena aterrado e ligado ao PEN da residência .......................... 98

Figura 6.05 - Exemplo de aterramento de antena pelo NEC ….................................... 98

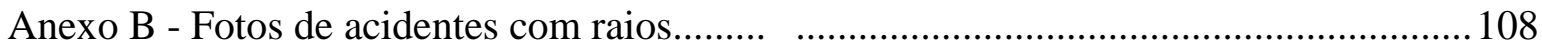




\section{LISTA DE TABELAS}

Tabela 2.01 - Densidade de descarga das capitais cobertas pelo RINDAT ….................... 17

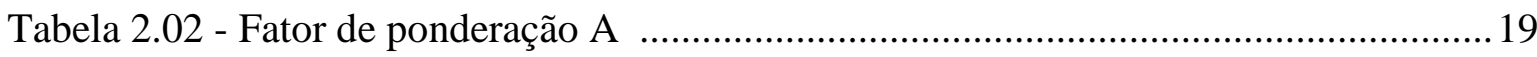

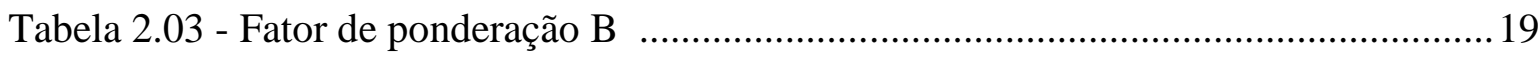

Tabela 2.04 - Fator de ponderação C........................................................................... 19

Tabela 2.05 - Fator de ponderação D ....................................................................... 20

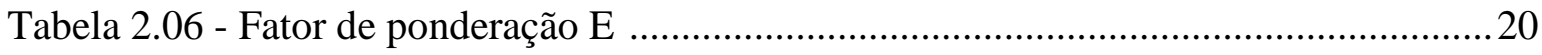

Tabela 3.01 - Intensidade das correntes de descarga direta.............................................. 22

Tabela 3.02 - Características das descargas atmosféricas................................................22

Tabela 3.03 - Espessura média dos cabos de descida...................................................... 30

Tabela 3.04 - Tensão total em função da seção transversal do cabo de descida ................... 30

Tabela 3.05 - Comparação entre SPDA e sistema de antena de TV ................................... 32

Tabela 4.01 - Níveis de eficiência de proteção................................................................... 42

Tabela 4.02 - Ângulos de proteção em função da altura....................................................50

Tabela 4.03 - Largura máxima entre cabos do reticulado...................................................52

Tabela 4.04 - Raio de atração em função da corrente de descarga .....................................54

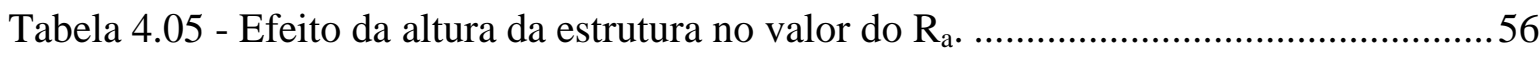

Tabela 5.01 - Faixa de valores usuais de resistividade ................................................. 71

Tabela 5.02 - Influência da concentração de sais na resist. do solo ..................................73

Tabela 5.03 - Dimensão dos eletrodos convencionais .................................................... 75

Tabela 5.04 - Seções mínimas dos condutores de aterramento ...........................................76

Anexo A - Classificação das estruturas quanto ao nível de proteção ................................. 107 
BEP Barramento de Equipotencialização Principal

BT Baixa Tensão

EES Equipamentos Eletrônicos Sensíveis

ELAT Grupo de Eletricidade Atmosférica (INPE)

EGM Electrogeometric Method (Método Eletrogeométrico)

EMC Electromagnetic Compatibility (Compatibilidade Eletromagnética)

EMI Electromagnetic Interference (Interferência Eletromagnética)

INPE Instituto Nacional de Pesquisas Espaciais

LEP Ligação Equipotencial Principal

LT Linha de Transmissão

NEC National Eletric Code (Código Elétrico Nacional)

PEM Pulso Eletromagnético

QEE Qualidade de Energia Elétrica RINDAT Rede Integrada Nacional de Detecção de Descargas Atmosféricas

SE Subestação SPDA Sistema de Proteção Contra Descargas Atmosféricas TAP. Terminal de Aterramento Principal 


\section{INTRODUÇÃO}

"Pessoal, eu até hoje fico na dúvida se uma antena de TV colocada sobre uma casa, sem nenhuma proteção de raios, pode ser perigosa. Muitas pessoas não têm nenhum sistema pára-raios e usam antenas de TV sem nem mesmo preocupar com os raios. Falem o que vocês souberem sobre antena externa e raios”. [Fórum Clube do Hardware, 2006]

Este comentário foi retirado de um fórum de discussões de informática. Pelas respostas percebeu-se que a dúvida era muito comum e que a solução dada muitas vezes se resumia ao número e geometria das hastes de aterramento para se alcançar um resistividade do solo menor que $10 \Omega$. A partir dessa indagação, normas, legislações, dados científicos e empíricos foram buscados com o intuito de formular uma resposta. A curiosidade pelo tema constituiu-se em grande motivação para a pesquisa.

O objetivo deste trabalho é fazer uma abordagem técnica dos riscos que representam as descargas atmosféricas para os sistemas de captação e transmissão de sinal, bem como para o ser humano, quando da falta de Sistema de Proteção contra Descargas Atmosféricas (SPDA). É Focado o fenômeno da tensão induzida sobre antenas de TV, visto que estas, normalmente instaladas no alto das edificações, comportam-se como captor natural, propiciando condições necessárias para um caminho de descida do raio durante tempestades. Como a instalação de antenas e cabos de comunicação não é realizada juntamente com a construção das residências, constata-se uma despreocupação com o aterramento da antena de TV, o que pode desencadear acidentes.

\section{1 - Metodologia}

Este trabalho foi desenvolvido em seis capítulos e anexos, assim distribuídos:

No capítulo 2 é apresentada uma breve introdução quanto ao estudo dos raios na história, passando pelo estudo e detecção do raio nos dias de hoje, das condições ambientais necessárias para a ocorrência uma descarga, dos elementos constituintes dos raios, e por fim, uma avaliação da possível necessidade de se instalar um SPDA. No capítulo 3, apresenta-se de forma detalhada a importância de se conhecer a força e capacidade dos raios no intuito de evitar os problemas físicos e financeiros causados todos 
os anos pelas descargas atmosféricas. Definem-se as situações de risco e suas consequiências. O capítulo 4 mostra os benefícios inerentes a uma boa proteção contra descargas atmosféricas, graças ao conhecimento de como a natureza se comporta, e como se prevenir das descargas. Aborda-se também a importância do bom dimensionamento dos subsistemas compostos de um SPDA. Foca-se também, a importância do estudo das correntes de retorno, da função de Heidler, e opção de adaptação de um SPDA a uma residência, proporcionando maior conforto e segurança aos seus habitantes. No Capítulo 5, os sistemas de proteção em Baixa Tensão são apresentados, detalhando-se o aterramento, a equipotencialização e outros tipos de proteção específicos, como centelhadores a gás. Um bom projeto de aterramento-equipotencial pode assegurar vida-útil prolongada para muitos equipamentos eletro-eletrônicos, e segurança aos freqüentadores da edificação. $\mathrm{O}$ capítulo 6 apresenta as conclusões às indagações que originaram este projeto, apresentando os argumentos para o aterramento de antenas de TV e um roteiro de vistoria de um SPDA para condomínios verticais encerra o capítulo 6. Por fim, no Capítulo 7 são apresentadas as conclusões, juntamente com alguns tópicos elencados como propostas de continuação deste estudo. 


\section{O RAIO NA HISTÓRIA}

A descarga atmosférica (ou raio) é um fenômeno natural que desde o início da humanidade desperta temor e curiosidade ao homem. Como a ação do raio é acompanhada pela luminosidade e trovoada, sua presença sempre foi respeitada e observada, tendo-se encontrado registros em 2000 A.C., na Mesopotâmia. Na antiguidade, o raio estava sempre associado a deuses e divindades, sendo fartamente apresentado na mitologia grega (Zeus), na mitologia nórdica (Thor), na mitologia oriental (Raiden), etc.. Com o decorrer dos anos os registros de raios passaram a ser rotinas, sendo citados em diversos documentos, inclusive na Bíblia. E foram muitos outros deuses "inventados" e cultuados para explicar as descargas atmosféricas. [34]

Devido a estas e outras situações, o raio sempre intrigou o ser humano, surgindo, de geração em geração, muitas fantasias e lendas sobre este desconhecido. Há relatos de costumes como o uso de pele de foca para proteção (como fazia o Imperador romano Augustos), ou ainda que deveriam dormir o mais tranquilamente possível para que no caso de um raio cair sobre a pessoa, este atravessaria seu corpo sem "resistência" e ela sairia ilesa.

Após a descoberta da eletricidade no início do século 18, a natureza elétrica da atmosfera da Terra começou a ser desvendada. Em 1708, William Wall, ao ver uma faísca sair de um pedaço de âmbar carregado eletricamente, observou que ela era parecida com um relâmpago. Na metade do século, após a descoberta das primeiras propriedades elétricas da matéria, tornou-se evidente que os relâmpagos deveriam ser uma forma de eletricidade, associada de alguma maneira com as tempestades. [34]

Nos dias de hoje, quando se trata de raios, quase que de imediato, pensa-se em Benjamin Franklin e seu experimento com uma pipa como o início do interesse científico do homem pelo raio. Até então, o homem já sabia como acumular cargas eletrostáticas através da fricção de determinados materiais [35], mas ainda não tinham a consciência que a descarga atmosférica tinha o mesmo princípio de funcionamento da transferência de cargas elétricas entre dois corpos, como quando alguém, após andar sobre um tapete acumulava cargas elétricas e ao tocar numa maçaneta metálica, sentia uma pequena descarga eletrostática. 
O experimento de Franklin consistia em obter faíscas elétricas entre um fio metálico preso a uma pipa nas proximidades de nuvens características de tempestades, e objetos metálicos enterrados (figura 2.01 - experimento de Franklin), em 1752. Assim, ele provou que as nuvens carregadas produziam relâmpagos (efeito visual do raio).

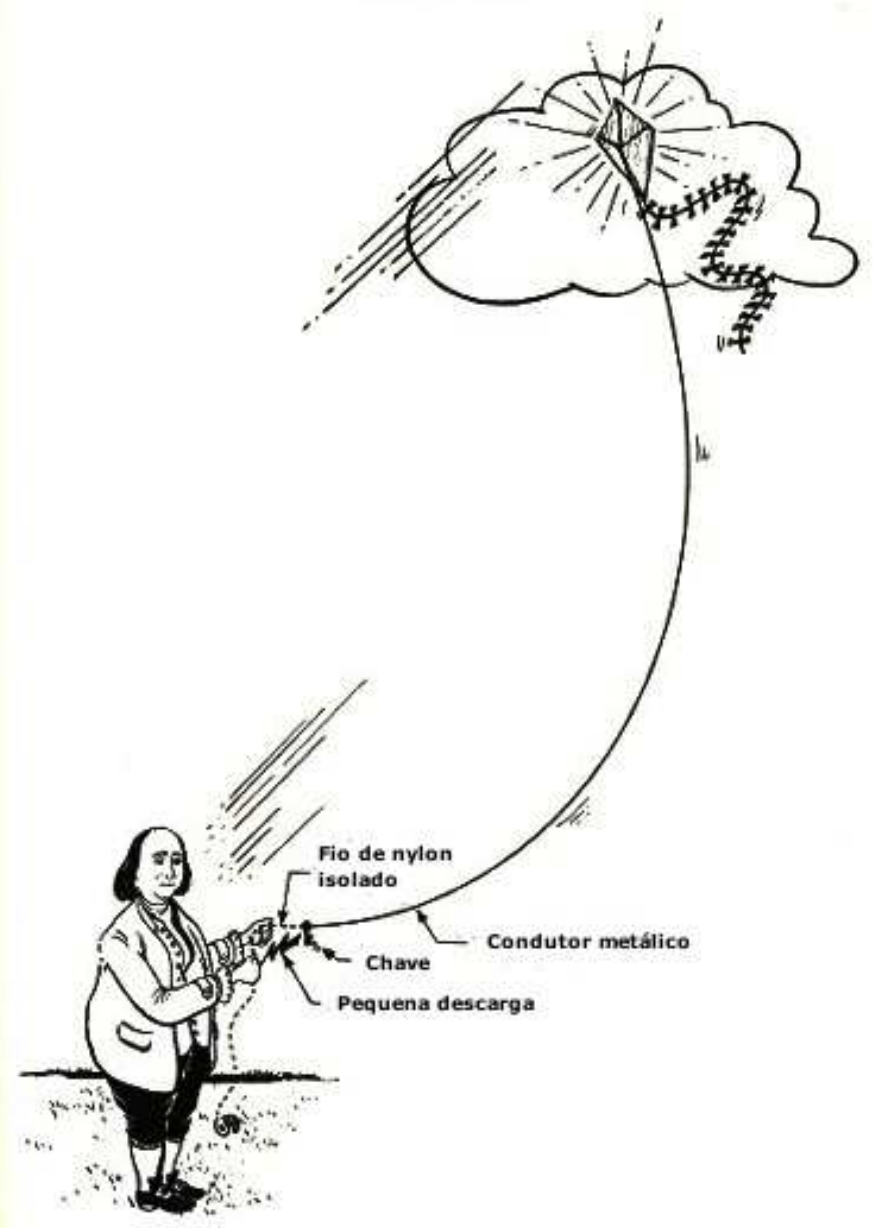

Figura 2.01 Experimento de Franklin [07]

Além desta famosa e bem sucedida experiência, Franklin propôs dois outros experimentos para comprovar a possibilidade de captar eletricidade da atmosfera.

Na figura 2.02a, um homem deveria estar isolado do chão, dentro de uma guarita de madeira, e segurando com uma das mãos uma haste metálica também isolada, mas com a ponta exposta à atmosfera, deveria constatar que, da outra mão, sairiam descargas para o ar. A $3^{\text {a }}$ experiência, bem parecida com a anterior, o individuo seguraria, através de uma peça isolante, um fio aterrado e constataria a existência de descargas entre o fio e a haste metálica (figura 2.02b). 


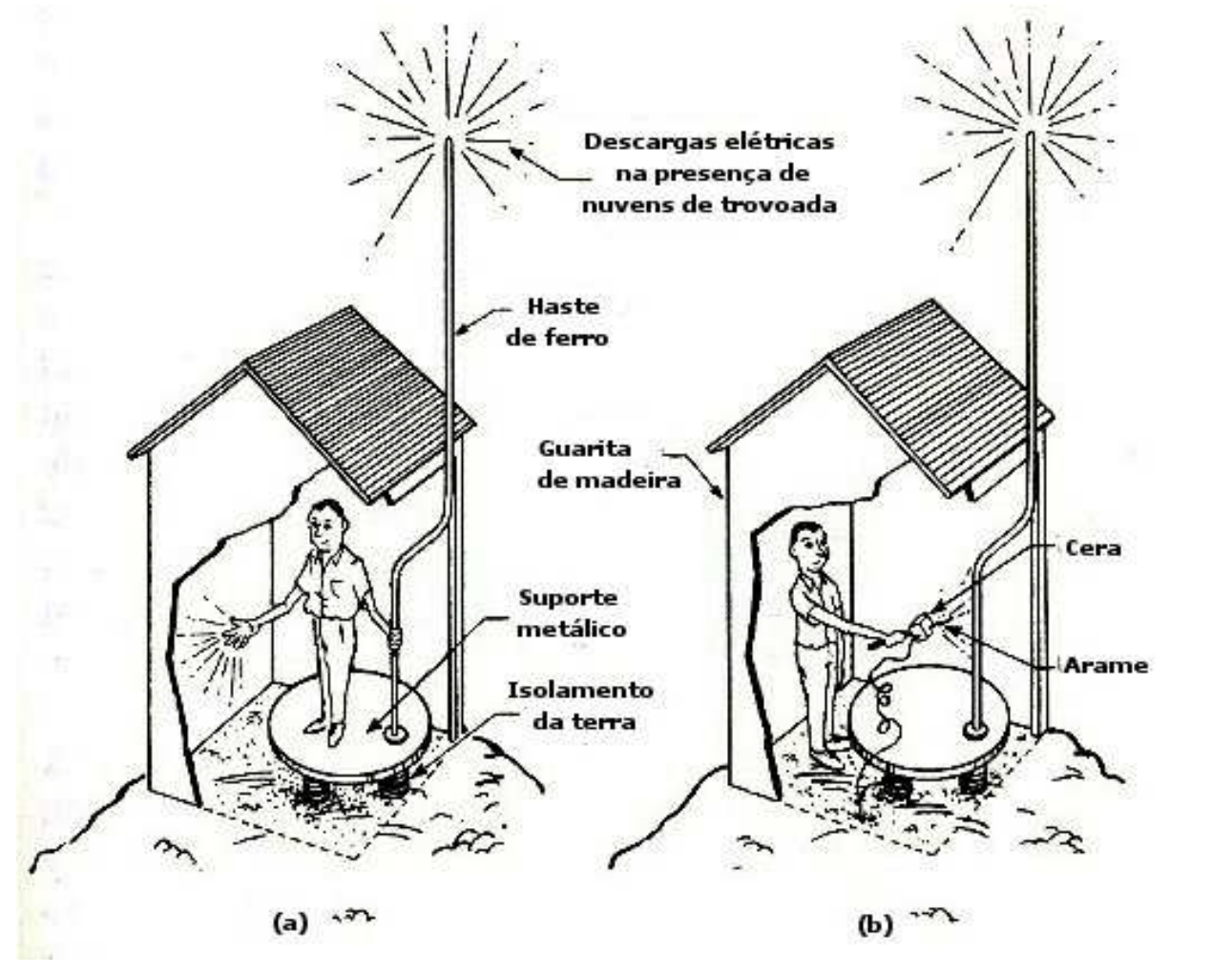

Figura 2.02 Outros experimentos de Franklin [07]

$\mathrm{Na}$ Europa, pesquisadores procuravam determinar os efeitos dos raios sobre os seres vivos através de experimentos com balões lançados em meio a tempestades, e ligados à terra através de fios metálicos ligados a animais, como cavalos por exemplo, observando e anotando suas reações. Obviamente, chegaram a conclusão que todas estas experiências eram perigosas e não podiam ser realizadas sem nenhum preparo depois que o pesquisador G. W. Richman, em 1753, faleceu ao ser atingido por uma violenta descarga direta, durante um experimento em que tentava captar eletricidade do alto da catedral de São Petesburgo [04].

Ainda no ano de 1752, o cientista francês Thomas-François D'Alibard realizou o $3^{\circ}$ experimento proposto por Franklin. D'Alibard levantou uma barra de ferro pontiaguda na direção de nuvens de tempestade e aproximou desta um fio aterrado, verificando que faíscas saltavam do mastro para o fio, o que além de provar a hipótese de Franklin, estabeleceu os princípios do funcionamento dos pára-raios.

Hoje se sabe que os relâmpagos estão relacionados à eletricidade na atmosfera. Eles iniciam com os raios, que nada mais são do que cargas elétricas em movimento ordenado, uma corrente elétrica na atmosfera produzindo dois efeitos: o relâmpago, resultado da iluminação de uma região específica do espaço onde elas se movimentam; e o trovão, gera 
ondas sonoras, produzidas pela dilatação do ar circunvizinho ao canal de descida do raio, capazes de serem ouvidas a quilômetros de distância de sua origem.

\section{1 - O circuito elétrico terrestre}

Acredita-se que os raios têm um largo efeito sobre nosso meio ambiente e que provavelmente estavam presentes durante o surgimento da vida na terra. Os raios podem ter colaborado na geração das moléculas que deram origem a vida. Pesquisas indicam que o aminoácido, substância que formou a crosta terrestre, tem origem nas descargas elétricas dos gases existentes na atmosfera. Independentemente da ação do homem, os raios provocam incêndios, constituindo-se em agentes naturais para a manutenção do equilíbrio da quantidade de árvores e plantas [06]. São também responsáveis por mudanças nas características da atmosfera ao redor das regiões onde ocorrem, quebrando moléculas de componentes do ar e produzindo novos elementos. Portanto, modificam a concentração de importantes elementos, como o gás ozônio, que se misturam com a chuva e precipitam como fertilizante natural. Apesar de tudo que é conhecido, os estudos sobre eletricidade atmosférica estão longe de se esgotarem, existindo ainda fenômenos de causas desconhecidas relacionados aos raios.

O planeta não apresenta um comportamento inerte do ponto de vista eletromagnético. Pelo contrário, existe toda uma dinâmica de processos elétricos e magnéticos em nosso planeta, que é responsável pelo equilíbrio das condições ambientais que asseguram a vida na terra. A esta dinâmica, dá-se o nome de circuito elétrico global.

O Circuito Elétrico Global é um modelo utilizado para explicar a diferença de potencial entre a Terra e a Ionosfera separados por uma camada de baixa condutividade. Nuvens de tempestades, com seus centros de carga positivo e negativo separados funcionam como o gerador de um circuito. Como podemos ver pela imagem abaixo, a corrente circula do topo das nuvens (carregado positivamente) para a Ionosfera. Passa pelos caminhos de alta condutividade dessa região e completa o circuito retornando ao solo pela região de tempo bom (sem nuvens de tempestades). O percurso da corrente se completa na região abaixo das nuvens (carregado negativamente) na forma de descargas atmosféricas. Dessa forma, os raios funcionam como um caminho por onde as nuvens transferem parte de suas cargas negativas para a terra. 


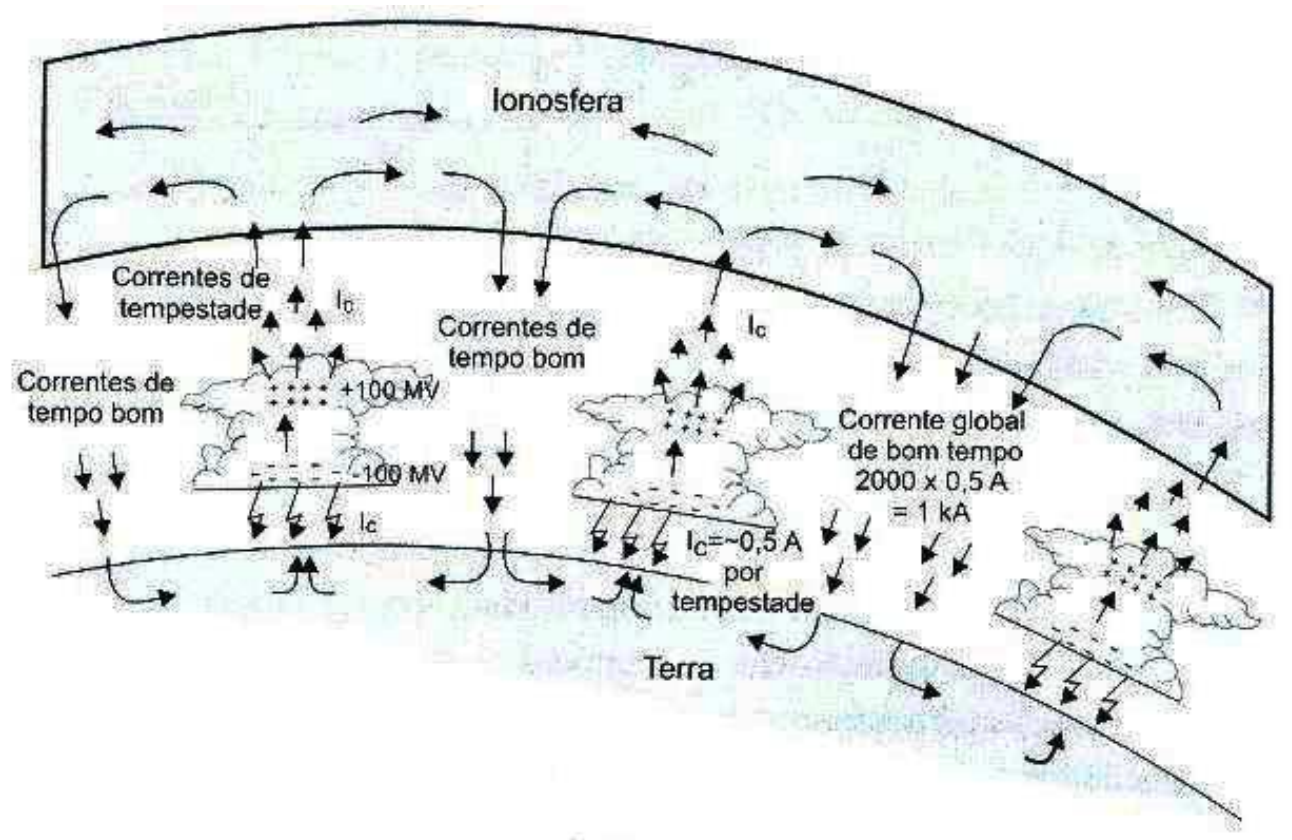

Figura 2.03 Circuito elétrico global [06]

A identificação das nuvens de tempestades como geradores nesse circuito ocorreu depois de duas constatações experimentais. A $1^{\mathrm{a}}$ surgiu depois que alguns experimentos demonstravam que as tempestades transferiam carga negativa para a terra. $\mathrm{Na} 2^{\mathrm{a}}$, verificouse a coincidência no período de ocorrência de dois eventos diários: máxima atividade de tempestades no globo terrestre e valor máximo do campo elétrico na superfície da terra, nas regiões de bom tempo. Essa coincidência indica que as tempestades são responsáveis pelo aumento do fluxo de corrente no circuito global e, por conseguinte, pela ampliação do campo nessas regiões.

Conforme podemos ver na figura 2.04, devido aos constantes estudos e observações das descargas atmosféricas, é possível estimar os valores de algumas grandezas associadas ao circuito elétrico global.

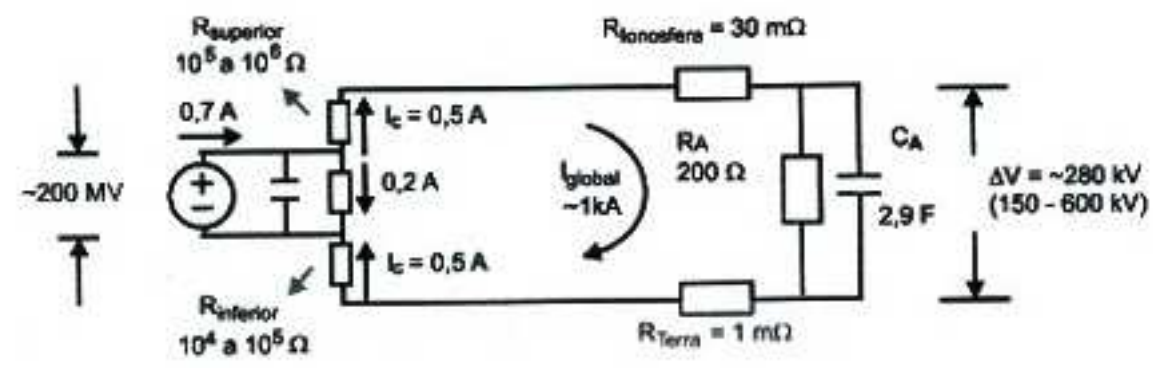

Figura 2.04 Circuito elétrico equivalente [06] 
Hoje, o estudo das descargas atmosféricas dispõe de ferramentas modernas e sofisticadas para o recolhimento de informações, como por exemplo o uso de foguetes lançados próximos de estações captadoras, capazes de criar um caminho de ar ionizado entre a terra e a nuvem, produzindo um ambiente perfeito para escoar o raio para a terra e, desta maneira examinar o raio através de máquinas fotográficas de alta velocidade, sem depender "da sorte" para que o raio atinja as torres captoras.

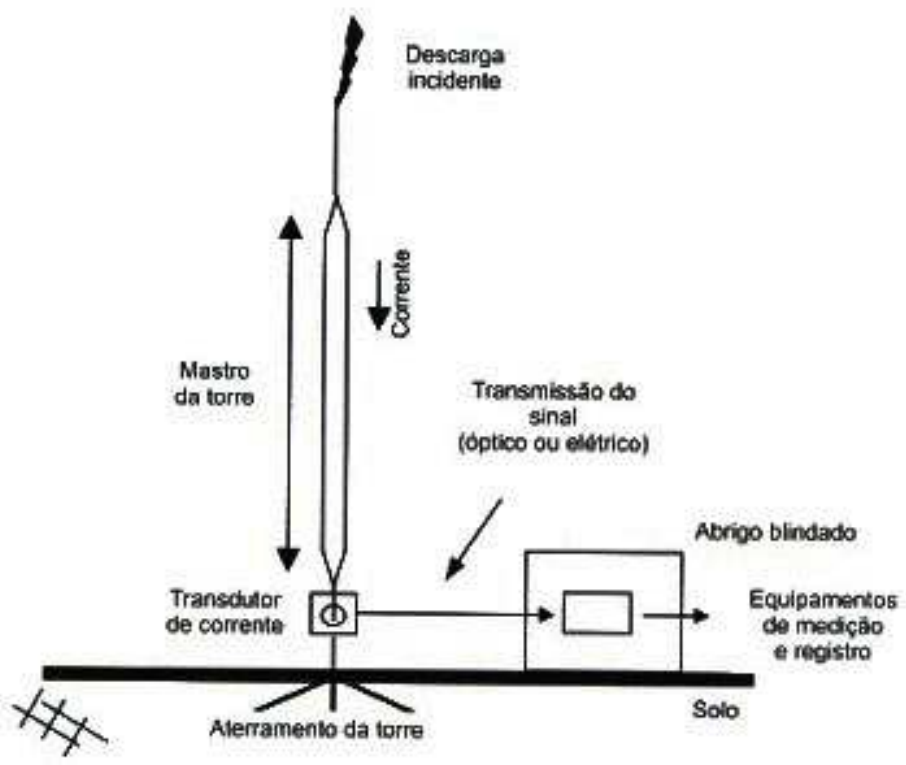

Figura 2.05 Estação fixa para medição de corrente de descarga [06]

\section{2 - A formação dos Raios}

As nuvens que acumulam cargas elétricas são nuvens convectivas de trovoada chamadas Cumulus Nimbus, com uma extensão vertical (tamanho vertical da nuvem) capaz de atingir de 9 a $12 \mathrm{~km}$ de altitude. Estas nuvens são formadas pelo encontro de correntes ascendentes de ar quente e úmido por partículas superesfriadas de sentido descendente, que podem ser causadas por processos de levantamento das massas de ar, resultantes de gradientes de pressão ou temperatura. A altitude da base da nuvem pode variar significativamente com a latitude, apresentando as maiores altitudes (cerca de $3 \mathrm{~km}$ ) sobre o equador e, gradativamente diminuindo até alturas inferiores a $1 \mathrm{~km}$ nas regiões de clima temperado. 
Como mostra a figura abaixo, o mecanismo de formação das cargs elétricas nas nuvens é bastante complexo. De alguma forma ainda não completamente entendida, as correntes ascendetes-descendentes de ar e a interação entre as particulas em suspenssão e em precipitação nas nuvens atuam para separar cargas positivas e negativas no interior das nuvens. Tais processos determinam a transferência de um excesso de cargas positivas para a parte superior da nuvem, deixando sua base excessivamente negativa.

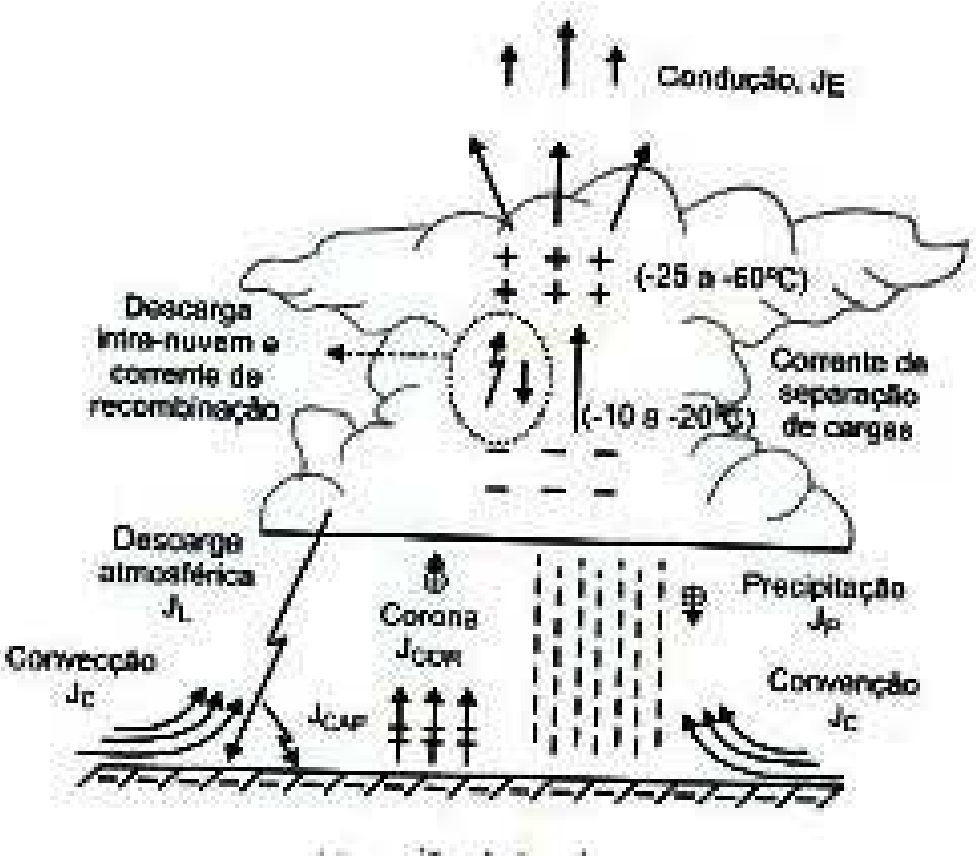

Figura 2.06 Circuito elétrico global [06]

Várias teorias tentam explicar detalhadamente este fenômeno. Uma das mais aceitas, diz que as cargas são produzidas por colisões de diferentes partículas de água e gelo de tamanhos variáveis. Correntes de ar ascendentes carregam umidade, que, chegando às regiões mais altas da atmosfera, se condensam e formam gotas de água que começam cair pela influência da gravidade. Nesta fase as gotas aumentam o seu tamanho ao se fundirem com outras gotículas fazendo o mesmo percurso. Chegando a um tamanho considerável, elas sentem a influência do campo elétrico da terra, cuja polaridade é negativa.

Com o passar do tempo, a medida que estas gotas vão ficando maiores, elas também vão ficando instáveis, e se fragmentam, deixando ions positivos na parte baixa, e ions negativos na parte alta. Os ions encontram as outras gotas no processo de subida e colidem com elas novamente. 
Ao colidir, as gotas ascendentes liberam elétrons para neutralizar os ions positivos, e continuam subindo carregadas positivamente. As fricções e o atrito entre as gotículas de chuva criam um ambiente ideal para a produção de grandes cargas de eletricidade na nuvem. Como essas gotículas possuem energia cinetica maior, elas chegam às maiores alturas dentro da nuvem, carregada de partículas eletrizadas, formam-se gradientes de tensão que variam entre 50 e $2500 \mathrm{~V} / \mathrm{cm}$; esta carga elétrica formada tende a descer para a terra e a eletricidade da terra tende a subir para a nuvem, no intuito de que ocorra a neutralização.

Por fim, a nuvem fica com sua base carregada negativamente e seu topo, positivamente. Este acúmulo de cargas negativas na base da nuvem induz uma concentração de cargas positivas na terra na região formada pela sua sombra, onde todos os corpos encontrados na terra, árvores, animais, prédios etc., ficam altamente carregados positivamente. Este fenômeno é conhecido como o poder das pontas.
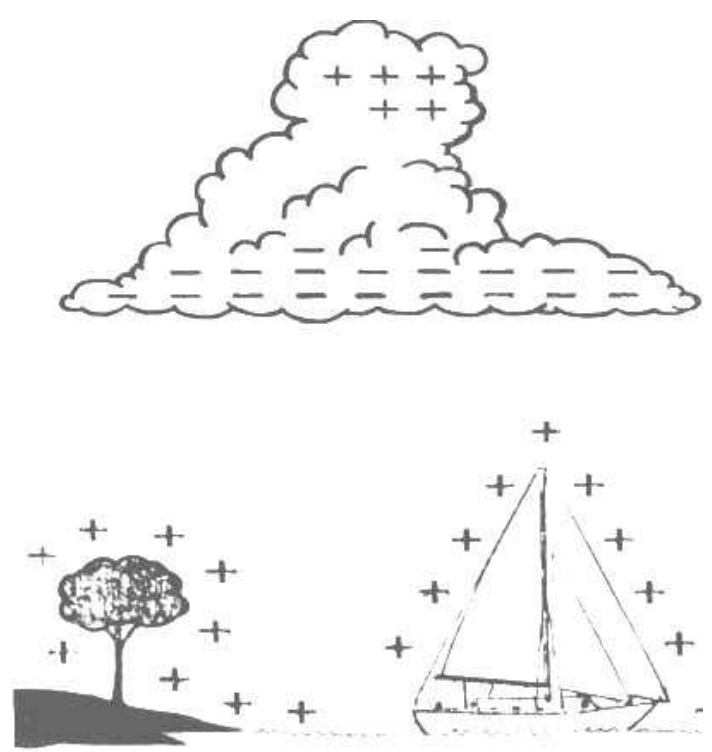

Figura 2.07 Indução de cargas positivas na sombra da nuvem [02]

\section{3 - O descarregamento para a terra}

Como visto anteriormente, uma nuvem com sua base carregada negativamente, induz no solo sob sua sombra um acúmulo de cargas de sinal contrário (positivas), estabelecendo uma enorme diferença de potencial entre sua base e a superfície do solo. $\mathrm{O}$ 
valor desta diferença de potencial pode ser muito elevado (várias centenas de megavolts) e o campo elétrico correspondente, igualmente intenso.

Quando campos elétricos intensos são desenvolvidos num meio dielétrico gasoso, pode ocorrer um processo físico associado à liberação dos elétrons das camadas mais externas dos átomos componentes do material, dando origem a uma descarga elétrica. Essa descarga é resultado da ruptura da rigidez dielétrica do material. A rigidez dielétrica é a capacidade de dado meio suportar um campo elétrico sem que haja ruptura do mesmo, corresponde ao valor máximo de campo elétrico sem que venha a perder suas características isolantes. No caso do ar, a rigidez dielétrica é de aproximadamente $3 \mathrm{MV} / \mathrm{m}$.

No entanto, para que uma descarga aconteça não é necessário que haja essa ruptura da rigidez dielétrica. No momento que a tensão em uma parte dessas camadas atinge o valor da rigidez dielétrica do ar $(=10 \mathrm{kV} / \mathrm{cm})$, se inicia o fenômeno através de pequenas cargas que escapam da nuvem e invisíveis correm através do ar, na forma de "jatos de eletricidade". Com a sucessiva ocorrência desses "jatos de eletricidade", começam a surgir regiões onde há uma diminuição na isolação do ar, causando pequenas alterações na sua trajetória, e preparando o caminho para outros "jatos".

Se permanecerem as condições necessárias de intensidade de campo elétrico, este caminho tende a evoluir por passos da ordem de $50 \mathrm{~m}$, devido a novas descargas disruptivas subseqüentes, em intervalos da ordem de $50 \mathrm{~ms}$. Ou seja, o raio começa a procurar caminhos ionizados (regiões de baixa isolação) e avançando em direção ao solo. Em alguns casos são constituídas ramificações neste canal descendente que evolui em direção ao solo, como se fossem galhos saídos do "tronco" principal, denominado líder.

À medida que o líder se aproxima do solo, na região abaixo do canal, aumentam a densidade das cargas positivas induzidas na superfície do solo e seu campo elétrico associado, concentrado "nas pontas" dos objetos mais altos. Lembrando que este poder das pontas é uma propriedade física caracterizada pelo acúmulo de cargas elétricas nas extremidades dos corpos condutores carregados eletricamente.

Quando o canal descendente alcança a distância de poucas centenas de metros da superfície do solo, dependendo das características do relevo local, o campo elétrico no solo torna-se tão intenso, que pode dar origem a descargas elétricas ascendentes. Estas podem ter extensão de várias dezenas de metros e seguem aproximadamente a direção do campo elétrico médio local, que aponta para cima.

No momento em que ocorre o fechamento (conexão) do canal entre nuvem e solo, é estabelecida uma onda de corrente de alta intensidade, conhecida como corrente de retorno. 
Esta se propaga pelo canal, a partir do ponto de conexão dos canais ascendente e descendente, neutralizando as cargas ali acumuladas, e dando origem a uma onda de corrente na base do canal, conforme seqüência da figura 2.08:

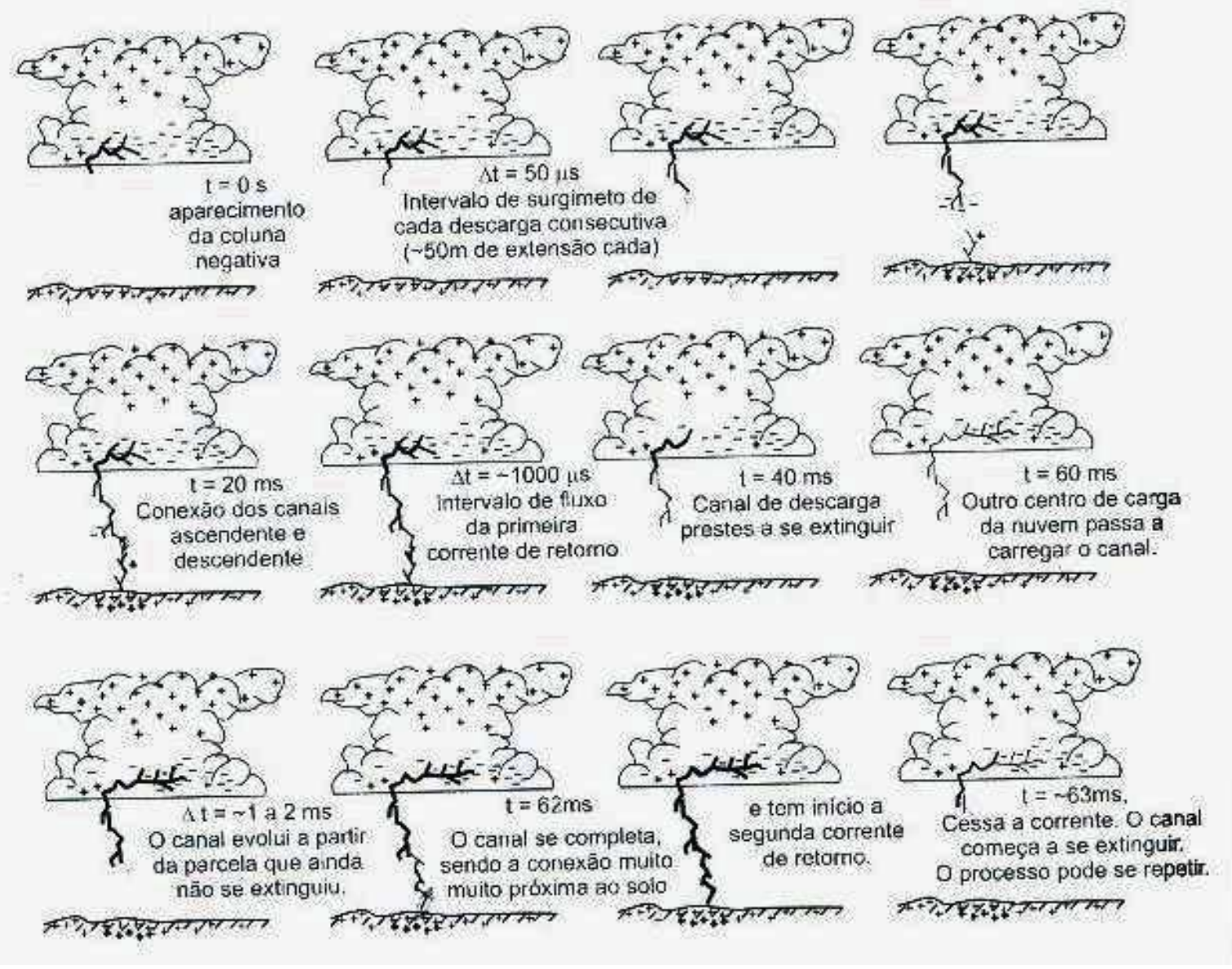

Figura 2.08 Processo de descarga nuvem-solo [06]

O processo de descarga nuvem-solo pode ser subdividido em descarga negativa e descarga positiva, conforme detalhado na figura 2.09.

- Descarga negativa - quando o canal de descarga é formado entre a região da nuvem carregada negativamente com a sombra da nuvem sobre a terra, carregada positivamente.

- Descarga positiva - quando o canal de descarga é formado entre a região da nuvem carregada positivamente com uma parte da terra nas imediações da região formada pela sombra da nuvem (carregada negativamente). 

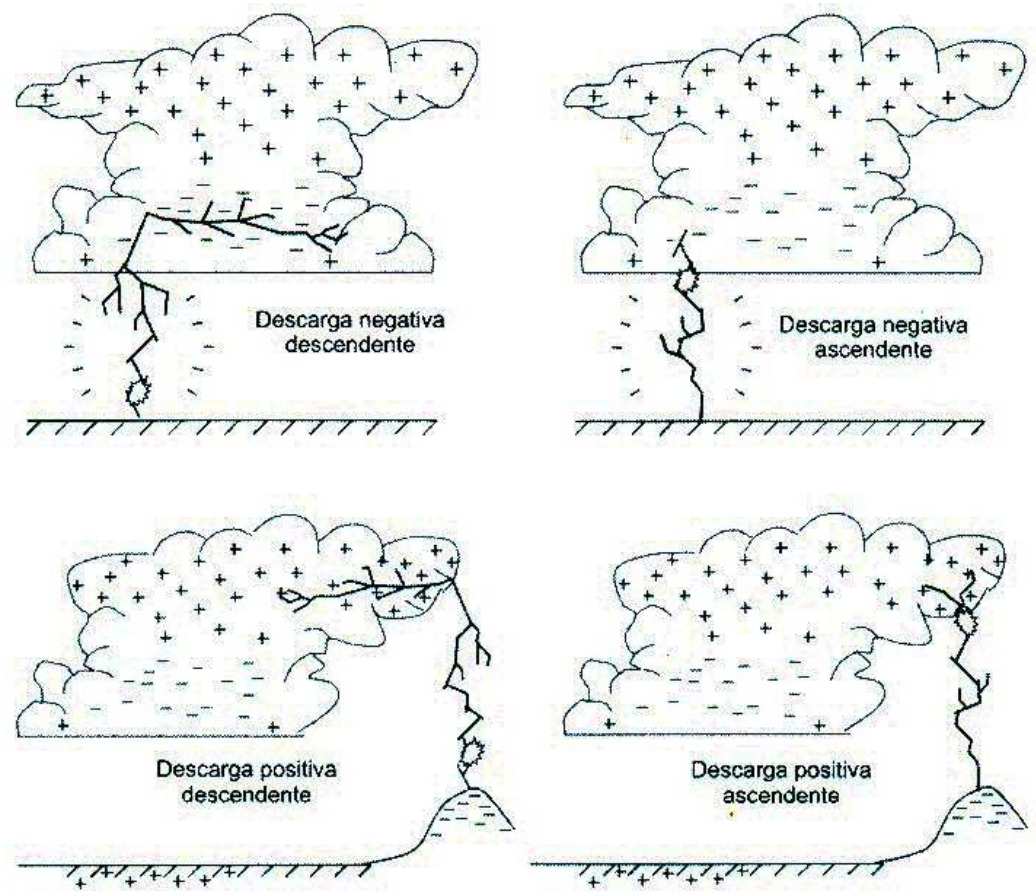

Figura 2.09 Tipos de descarga nuvem-solo [06]

\section{4 - A composição do raio}

Quando o piloto em sentido ascendente se encontra com o piloto em sentido descendente, e fecham o circuito, surge daí a descarga de retorno, cuja grande intensidade produz rápida elevação da temperatura no centro do canal ionizante, provocando um brilho intenso (relâmpago), e uma rápida expansão do ar, traduzido em ondas sonoras (o trovão).

Através dessas manifestações sensoriais (relâmpago e trovão) é possível estimar a distância que nos separa do ponto onde o raio caiu. Ao observar visualmente a ocorrência de um relâmpago, acionamos um cronômetro e verificamos o tempo (em segundos) decorrido até ouvirmos o som do trovão. Como o relâmpago se manifesta na velocidade da luz, o momento de seu surgimento torna-se o tempo inicial do "experimento". Multiplicando o tempo até o momento do trovão, em segundos, por 340 (a velocidade do som no ar é de $340 \mathrm{~m} / \mathrm{s}$ ) teremos a distância identificada. Por exemplo: se o tempo decorrido entre o aparecimento do clarão e a audição do trovão for de aproximadamente 10 segundos, o raio terá caído a uma distância de aproximadamente 3.400 metros.

Recentemente, surgiram métodos de localização dos raios, que permitem acompanhar o desenvolvimento das tempestades em monitores. Alguns desses sistemas 
permitem na apenas localizar os pontos de queda dos raios, como também cotá-los e determinar seus parâmetros, enquanto outros atuam como supervisores para indicar a aproximação das tempestades.

A Lightning Location and Protection (LLP) desenvolveu um sistema baseado na medição dos campos eletromagnéticos gerados pelas descargas nuvem-terra. São instalados três sensores distantes dezenas de quilômetros da base de pesquisas, capazes de reconhecer o tipo de descarga (se nuvem-nuvem ou nuvem-terra) e envia à base somente os dados referente a descargas nuvem-terra.

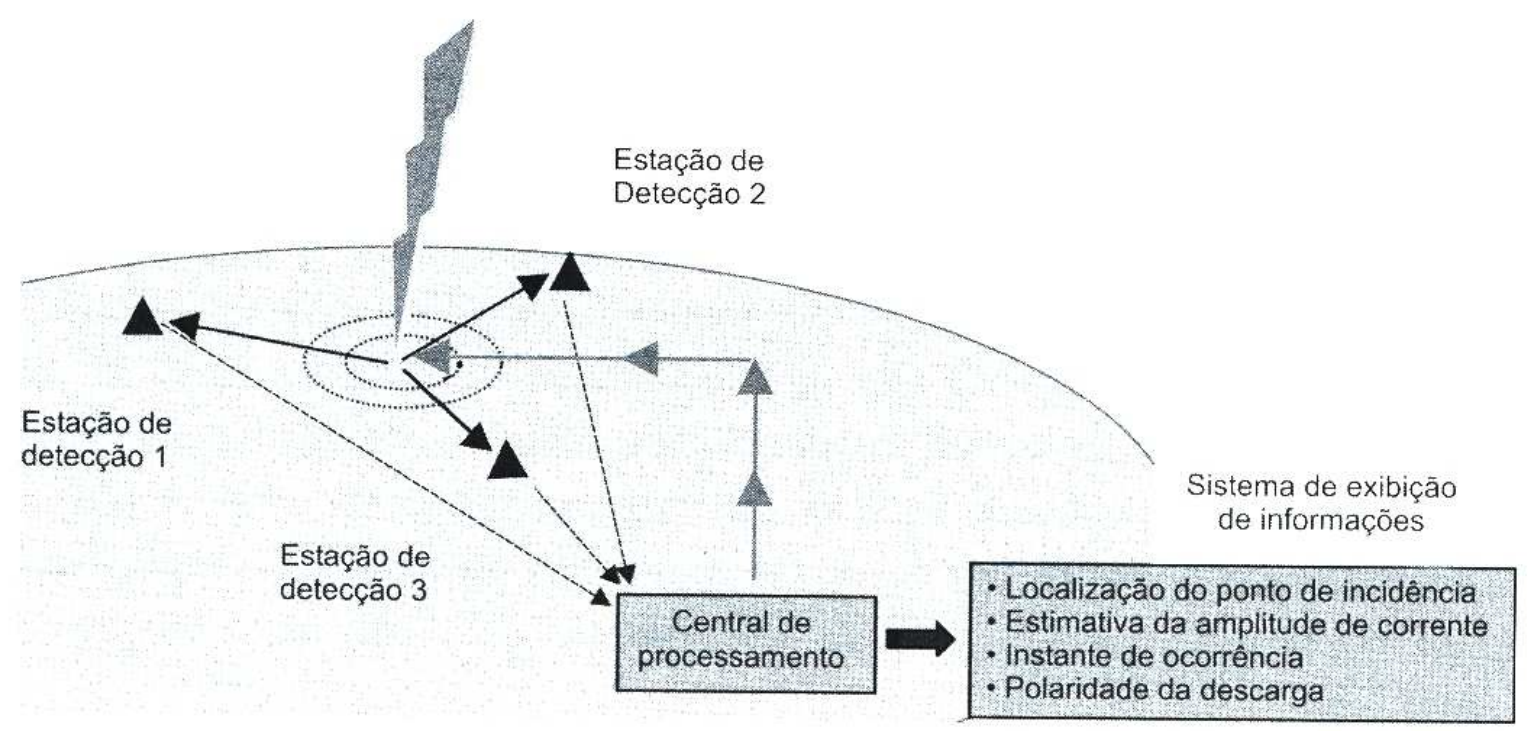

Figura 2.10 Sistema de localização otimizado [06]

Conforme imagem acima, cada sensor (ou antena), ao receber um sinal positivo, localiza o ângulo dentro do qual ocorreu a descarga. Combinando o resultado de 2 sensores, calcula-se a distância da queda, enquanto um $3^{\circ}$ sensor é utilizado para refinar a localização da queda. [17]

Pode-se destacar o sistema norte-americano de detecção de descargas (Rede Integrada de Detecção de Descargas) pela alta densidade de sensores por unidade de área, o que lhe confere altos índices de eficiência e confiabilidade; e o sistema denominado Rede Euclides, composto pelos sistemas de vários países da União Européia, que trabalhando juntos têm conseguido ótimos resultados na detecção e análise das descargas [06].

No Brasil, O ELAT, Grupo de estudo de Eletricidade Atmosférica do Instituto Nacional de Pesquisas Espaciais (INPE) mapeia a ocorrência de raios em todos os municípios das regiões Sul e Sudeste e em boa parte da Região Centro-Oeste do país. Em números 
absolutos, Corumbá em Mato Grosso do Sul apresentou o maior número de raios. No total foram 568.405 raios no período analisado. Os dados do estudo são da Rede Brasileira de Detecção de Descargas Atmosféricas (RINDAT). [36]

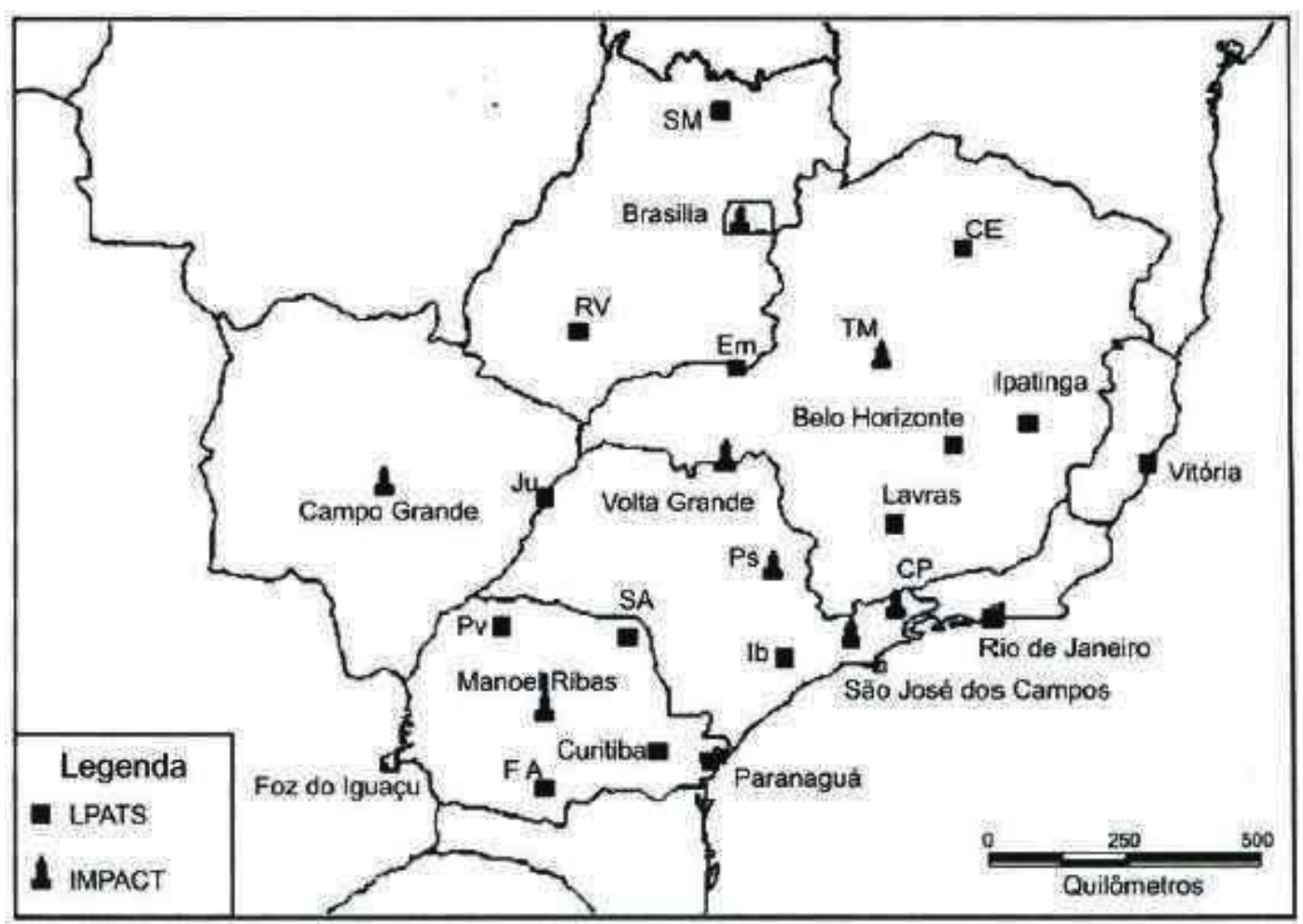

Figura 2.11 Área de cobertura do RINDAT [ELAT, 2008]

A trovoada pode ser definida como o conjunto dos fenômenos eletromagnéticos, acústicos e luminosos que ocorrem numa descarga atmosférica. O índice ceráunico corresponde ao número de dias de trovoada que ocorrem por ano em uma dada localidade. A partir da observação ao longo do tempo, pode-se projetar estimativas baseando-se nos dados anteriores.

Ou seja, o índice ceráunico é uma estimativa baseada na observação auditiva do número de dias que ocorreram trovoadas por ano, por $\mathrm{km}^{2}$. O problema deste índice é que ele considera apenas se houve uma trovoada em dado dia ou não; não fazendo distinção entre um dia todo de trovoadas e apenas uma pequena trovoada a nível nuvem-nuvem, num dia qualquer.

O observador (ceraunômetro) deve registrar as trovoadas dentro de sua localidade. A distância estimada da ação do observador é de um círculo com raio de 20 quilômetros. Registrando todos os índices ceráunicos em um mapa, e ligando os pontos de igual 
intensidade, obtêm-se as linhas de mesmo índice, isto é, índices isoceráunicos. O mapa isoceráunico do Brasil está apresentado na figura abaixo, seguido de uma tabela contendo os índices por capitais:

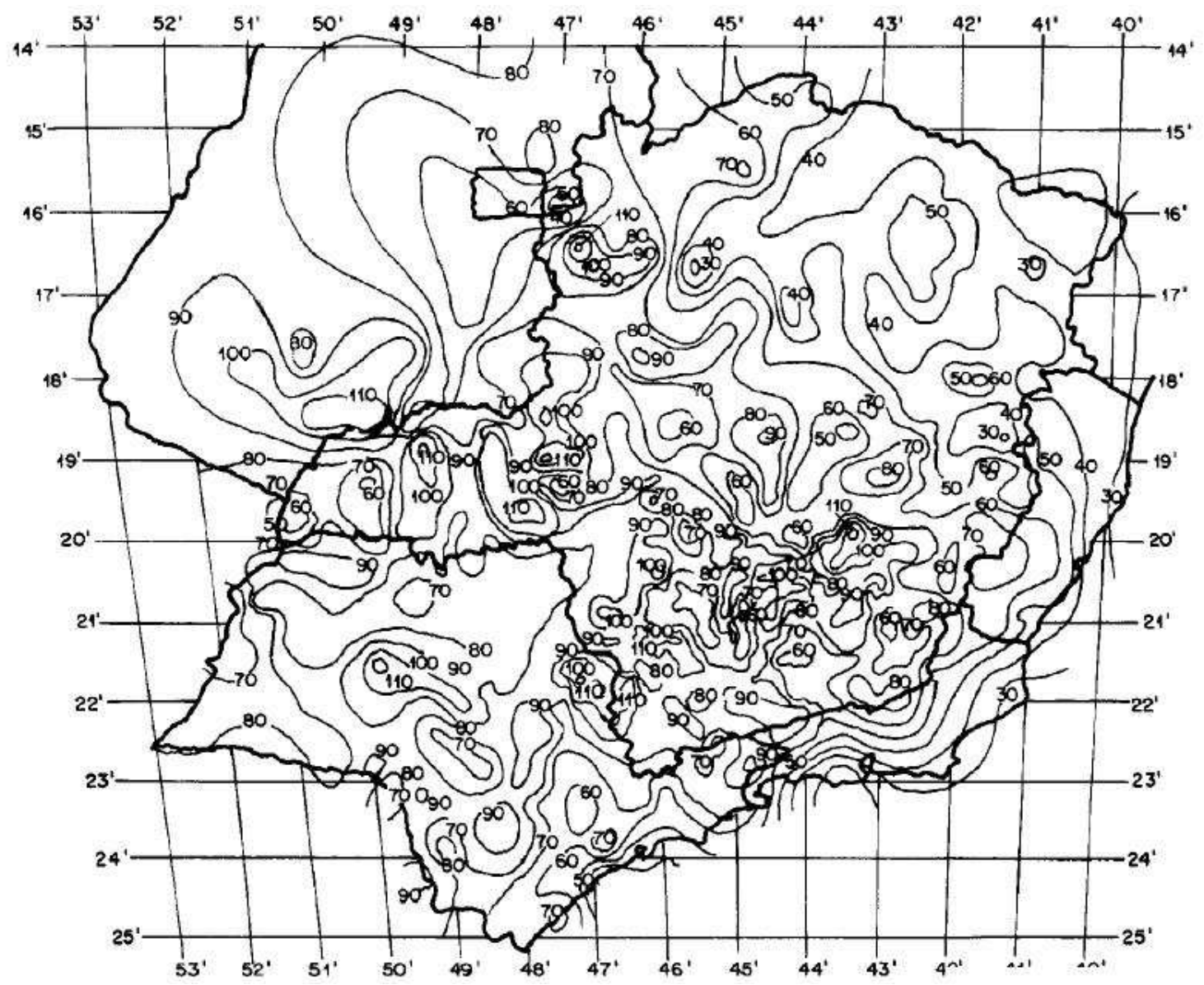

Figura 2.12 Mapa ceráunico da região SE e parte do CO [06]

A determinação da densidade de raios é feita através de contadores CIGRÉ, que são dispositivos contendo uma antena que capta as radiações eletromagnéticas emitidas pelos raios e as registra em um dispositivo contador, tendo um raio de cobertura de $20 \mathrm{~km}$.

\section{5 - Probabilidades de queda}

Para se calcular a densidade de descargas atmosféricas nuvem-terra sobre uma dada região, durante o período de um ano, multiplica-se a quantidade de descargas atmosféricas para a terra (de acordo com os dados coletados pelos contadores CIGRÉ) pela área de exposição equivalente da estrutura (região estendida da estrutura suscetível à atração de 
descargas, conforme veremos mais afrente). Então, a densidade de descargas atmosféricas para a terra $\left(\mathrm{N}_{\mathrm{g}}\right)$ é o número de raios (para a terra) por quilômetros quadrados, por ano. $\mathrm{O}$ valor de $\left(\mathrm{N}_{\mathrm{g}}\right)$ para uma dada região pode ser estimado pela equação:

$$
N_{g}=0,04 . T d^{1,25} \quad\left[k^{2} / \text { ano }\right]
$$

onde $\boldsymbol{T d}$ é o número de dias de trovoada por ano, obtido de mapas isoceráunicos, conforme a figura acima.

A tabela 2.01 traz a densidade de descargas atmosféricas das capitais do Sudeste e parte do Centro-Oeste, conforme mapa ceráunico anterior - figura 2.11.

Tabela 2.01 Densidade de descarga das capitais cobertas pelo BrasilDAT [36]

\begin{tabular}{|c|c|c|}
\hline CAPITAL & $\mathrm{Ng}(2005 / 2006)$ & $\mathrm{Ng}(2007 / 2008)$ \\
\hline Belo Horizonte & 3,7891 & 3,6604 \\
\hline Brasília & 1,0129 & 1,4623 \\
\hline Goiânia & 1,5326 & 2,0646 \\
\hline Rio de Janeiro & 2,2403 & 1,8531 \\
\hline São Paulo & 8,1406 & 9,7934 \\
\hline Vitória & 0,4783 & 0,8995 \\
\hline
\end{tabular}

São várias as propostas de diferentes autores ou documentos sobre como levar em conta a influência da altura. As normas inglesa (BS 6651-1991), alemã (VDE 0185) e brasileira (NBR 5419/2004) consideram que a área a ser considerada deve ser a da vista em planta aumentada proporcionalmente a uma vez a altura da estrutura, enquanto a norma IEC 61024-I considera um aumento igual a 3 vezes a altura. Uma observação interessante quanto a esta questão está no fato da norma inglesa trabalhar com este critério desde sua $1^{\mathrm{a}}$ edição em 1965 sem modificações, pois a experiência mostrou-se acertada [04].

A esta área aumentada damos o nome de área de atração, significando que este seria a região sob influência da altura da estrutura, dada por:

$$
A_{a}=L \cdot W+2 \cdot(L+W)+\pi \cdot H^{2}
$$

Posto isto, a área de atração para uma estrutura retangular, conforme figura 2.13, será: 


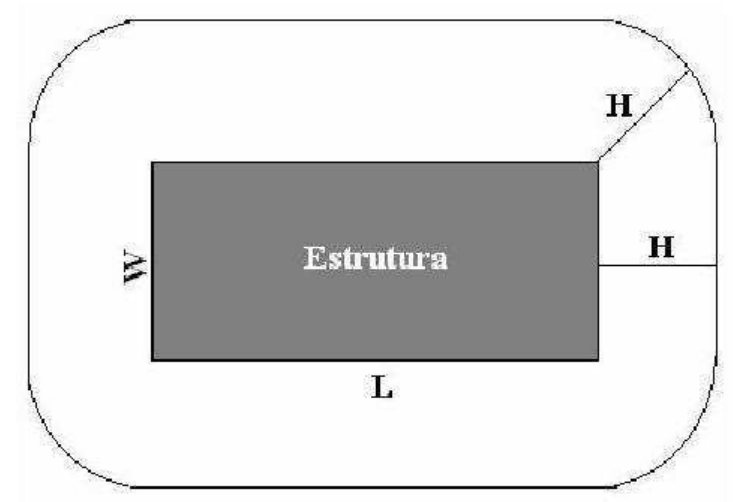

Figura 2.13 Área de cobertura de um paralelepipezóide [24]

A partir da área de atração calculada, pode-se calcular a probabilidade de queda de raios sobre a estrutura pela expressão:

$$
N_{d}=A_{a} \cdot N_{g} \cdot 10^{-6}
$$

[raios / ano $]$

A probabilidade de uma estrutura ser atingida por um raio, ou seja, de quantos em quantos anos pode acontecer de dada estrutura ser atingida por um raio, é dada pela expressão acima.

A partir do conhecimento da probabilidade de um raio cair em dada estrutura, e levando-se em consideração o tipo de material que esta estrutura protege, o material de que é feita, a ocupação e localização topográfica podemos determinar o risco de haver algum dano a ela, devido a uma descarga atmosférica.

A vantagem deste método é que ele fornece um parâmetro de decisão ( $\mathrm{Nc}$ ) quanto à necessidade ou não de proteção contra descargas atmosféricas. O método americano (NFPA 780) fornece vários níveis de risco, mas deixa a decisão final para o projetista. A NBR 5419 leva em conta várias situações como ambiente e material, como parâmetro multiplicador, juntamente com a área de atração, para então chegar num número que represente o risco de dano à estrutura e (ou) dano pessoal.

$$
N_{c}=N_{d} \text {.A.B.C.D.E }
$$

onde $\mathrm{A}, \mathrm{B}, \mathrm{C}, \mathrm{D}$ e $\mathrm{E}$ representam um fator definido conforme alguns aspectos definidos como segue. 
- Fator A - Tipo de ocupação da estrutura

- Fator B - Tipo de construção da estrutura

- Fator C - Conteúdo da estrutura e efeitos indiretos das descargas

- Fator D - Localização da estrutura

- Fator E - Topografia da região

A proteção será necessária se $\boldsymbol{N}_{\boldsymbol{c}}<\mathbf{1 0 ^ { - 5 }}$ e obrigatória se $\boldsymbol{N}_{\boldsymbol{c}}>\mathbf{1 0 ^ { - 3 }}$. Se o resultado for um número intermediário, ou seja, $10^{-3}>N_{c}>10^{-5}$, a decisão fica a cargo do projetista.

Uma curiosidade quanto a este número $\left(\mathrm{N}_{\mathrm{c}}\right)$ é que ele foi obtido depois de analisadas várias causas de morte na Inglaterra. Desde o hábito de fumar (a maior, com uma morte para cada 400 fumantes por ano - ano de 1965), passando pelos acidentes de transito, doenças diversas, acidentes naturais, até chegar a probabilidade de morte por raio ( uma morte para cada 2.000.000 por ano). $\mathrm{O}$ valor $10^{-5}$ representa a probabilidade de uma pessoa morrer pelo simples fato de estar viva! [04]

Tabela 2.02: fator de ponderação em função do tipo de ocupação [24]

\begin{tabular}{|c|c|}
\hline Tipo de Ocupação & Fator A \\
\hline Casas & 0,3 \\
\hline Casas com antena externa & 0,7 \\
\hline Fábricas, laboratónios & 1,0 \\
\hline Escritórios, hotéis, apartamentos & 1,2 \\
\hline Museus, exposições, shoppings, centers, estádios & 1,3 \\
\hline Escolas, hospitais & 1,7 \\
\hline
\end{tabular}

Tabela 2.03: fator de ponderação em função do material da construção e da cobertura [24]

\begin{tabular}{|c|c|}
\hline Material de Construção & Fator B \\
\hline Metal revestido, cobertura não metálica & 0,2 \\
\hline Concreto, cobertura não metálica & 0,4 \\
\hline Metal o concreto, cobertura metálica & 0,8 \\
\hline Alvenaria & 1,0 \\
\hline Madeira & 1,4 \\
\hline Alvenaria ou madeira com cobertura metálica & 1,7 \\
\hline Cobertura de Palha & 2,0 \\
\hline
\end{tabular}

Tabela 2.04: fator de ponderação em função do conteúdo [24]

\begin{tabular}{|c|c|}
\hline Conteúdo & Fator C \\
\hline Comum, sem valor & 0,3 \\
\hline Sensível a danos & 0,8 \\
\hline Subestações, gás, radio, TV, telefönica & 1,0 \\
\hline Museu, monumentos, valores especiais & 1,3 \\
\hline Escolas, hospitais & 1,7 \\
\hline
\end{tabular}


Tabela 2.05: fator de ponderação em função da localização [24]

\begin{tabular}{|c|c|}
\hline Localização & Fator D \\
\hline Rodeado pro árvores ou estruturas & 0,4 \\
\hline Semi-isolada & 1,0 \\
\hline Isolada & 2,0 \\
\hline
\end{tabular}

Tabela 2.06: fator de ponderação em função da topografia [24]

\begin{tabular}{|c|c|}
\hline Topografia & Fator E \\
\hline Planicie & 0,3 \\
\hline Colina & 1,0 \\
\hline Montanha, 300 a 900 metros & 1,3 \\
\hline Montanha, acima de 900 metros. & 1,7 \\
\hline
\end{tabular}

Por exemplo, consideremos a avaliação do risco de exposição de um bloco de apartamentos, de seis andares, situado próximo ao Lago Paranoá, com dimensões de aproximadamente $20 \times 60 \times 30$.

$$
\begin{aligned}
& N_{g}=1.4623 \rightarrow \text { Brasília } \\
& A e=(20 \cdot 60)+2 .(20+60)+\left(\pi \cdot 30^{2}\right)=4,1874.10^{3} \mathrm{~m}^{2} \\
& N_{d}=N_{g} \times A e \times 10^{-6}=6,1233.10^{-3}
\end{aligned}
$$

Consideremos agora:

Fator $\mathrm{A}=1,2$ (edifício de apartamentos)

Fator $\mathrm{B}=0,4$ (estrutura de concreto com cobertura não metália)

Fator $\mathrm{C}=0,3$ (residência comum)

Fator $\mathrm{D}=0,4$ (rodeado por árvores ou estruturas)

Fator $\mathrm{E}=0,3$ (planície)

$$
\begin{aligned}
& N_{c}=N_{d} \times A \times B \times C \times D \times E=0,68 \times 10^{-3} \\
& N_{c}=\left(6,1233.10^{-3}\right) \times(1,2) \times(0,4) \times(0,3) \times(0,4) \times(0,3) \\
& N_{c}=105,81.10^{-6}
\end{aligned}
$$

Como $\mathrm{N}_{\mathrm{c}}$ está entre $10^{-6}$ e $10^{-3}$, então a decisão por instalar um SPDA ficaria por conta do projetista e(ou) do cliente. 


\section{OS RISCOS}

Existe uma estimativa de 2.000 trovoadas em progresso, a todo o momento. A maior proporção das mesmas ocorrendo nos trópicos, onde calor, muita umidade e instabilidade estão sempre presentes. Cerca de 45.000 trovoadas ocorrem todos os dias e mais de 16 milhões ocorrem anualmente no mundo inteiro.

A cada segundo, cerca de 100.000 raios caem sobre a Terra, produzidos por cerca de 2.000 tempestades. A formação de cargas nas nuvens, e sua conseqüente descarga à Terra causam prejuízos e mortes [08].

\section{1 - A potência de um raio}

O tempo médio de duração de uma corrente de descarga aproxima-se de $300 \mu \mathrm{s}$ [06]. No entanto, dentro deste curto período de tempo, pode-se destacar três partes deste processo de descarga: o tempo de subida (o tempo necessário para que o raio atinja seu valor máximo) da ordem de $1,2 \mu \mathrm{s}$; o tempo de meia onda (o tempo necessário para que a onda atinja $50 \%$ do valor de pico) da ordem de $50 \mu \mathrm{s}$; e a cauda da onda (tempo a partir do tempo de subida, seguido por um período mais longo e suave, com duração de $200 \mu$ s, no qual a corrente decai até desaparecer.

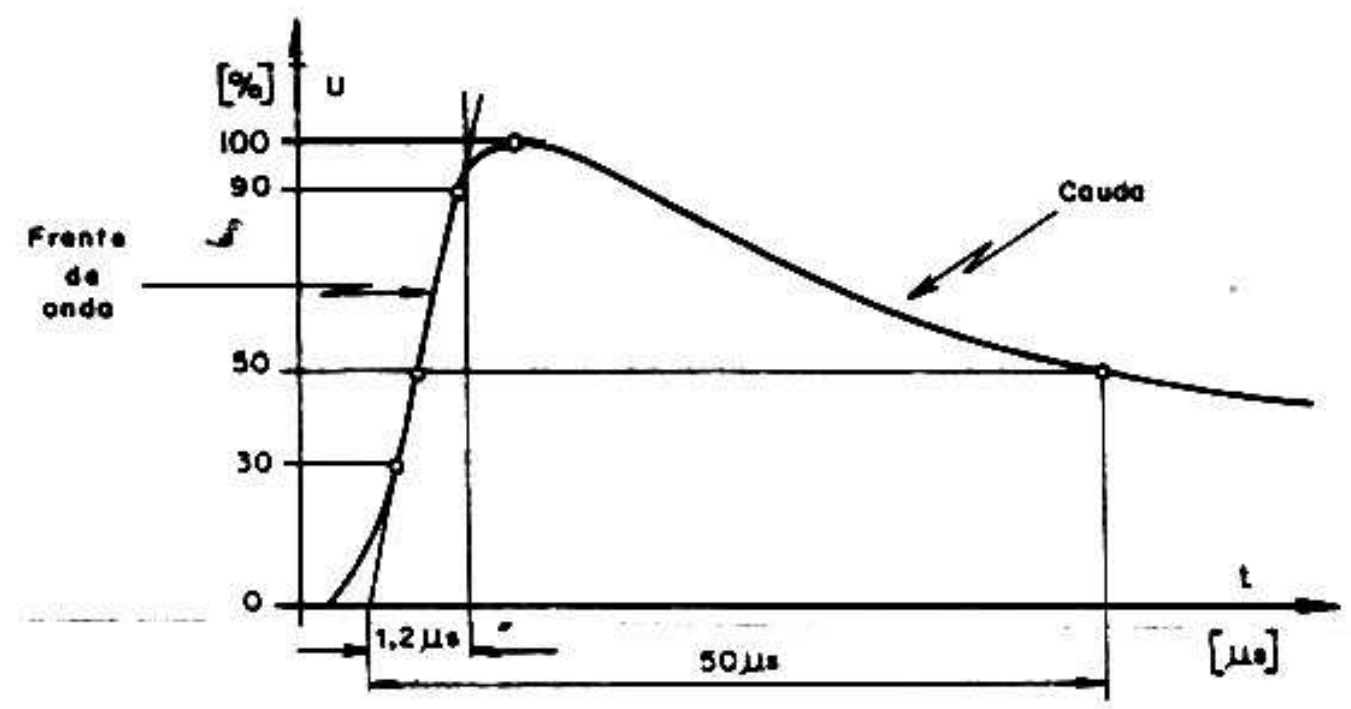

Figura 3.01 Forma da onda de um raio [02] 
A importância desta informação está no fato de que os equipamentos de proteção são elaborados para resistir a valores da ordem de "meia cauda" da onda. Ou seja, se o equipamento puder resistir a esta intensidade de corrente por cerca de $65 \mu$ s, então as chances dele sobreviver ao restante da onda serão grandes, visto que a onda tende a diminuir.

Com o desenvolvimento dos instrumentos de medição elétrica tornou-se possível avaliar as propriedades das descargas atmosféricas, instalando esses instrumentos em pontos elevados (em torres, edifícios, etc.) bem como nas redes de distribuição elétrica. Percebeu-se que a maioria das descargas atmosféricas (cerca de 94\%) atingem até 60.000A; conforme tabela abaixo:

Tabela 3.01: Intensidade das correntes de descarga direta [02]

\begin{tabular}{|c|}
\hline DESCARGAS DIRETAS DE RAIOS \\
\hline $0,1 \%$ excedem 200.000 Amperes \\
\hline $0,7 \%$ excedem 100.000 Amperes \\
\hline $6,0 \%$ excedem 60.000 Amperes \\
\hline $50,0 \%$ excedem 15.000 Amperes \\
\hline
\end{tabular}

A tensão elétrica causada pelo raio pode atingir, inicialmente, centenas de milhões de volts entre as nuvens e a terra, sendo vários milhões de volts podem ser transferidos para o objeto atingido durante a ocorrência da descarga elétrica do raio. A tensão dependerá da intensidade de corrente do raio, da condutibilidade do objeto atingido e da impedância existente entre o ponto atingido e o terra. No caso de janelas de metal, cercas e outros objetos metálicos, raios que caiam próximos podem induzir tensões elevadas com grande risco de acidentes.

Tabela 3.02: Características das descargas atmosféricas [02]

\begin{tabular}{|c|c|}
\hline Registros Coletados & Valores \\
\hline Corrente & 2000 a 200.000 Amperes \\
\hline Tensão & 100 a $1.000 .000 \mathrm{kV}$ \\
\hline Duração & 70 a $200 \mu \mathrm{s}$ \\
\hline Carga elétrica da nuvem & 20 a $50 \mathrm{C}$ \\
\hline Potência liberada & 1000 a 8.000 milhões de kW \\
\hline Energia & $410 \mathrm{kWh}$ \\
\hline Tempo de crista & $1,2 \mu \mathrm{s}$ \\
\hline Tempo de meia cauda & $50 \mu \mathrm{s}$ \\
\hline
\end{tabular}


No caso de acidentes envolvendo descargas atmosféricas, há basicamente 2 formas de ocorrer: descargas diretas e descargas indiretas, cuja diferença está na forma como a descarga atinge o solo ou outras estruturas.

\section{2 - Descargas Diretas}

Descargas diretas ocorrem quando do raio (ou uma de suas ramificações) termina sobre o individuo. Quando isso acontece, valores muito elevados de corrente impulsiva podem circular pelo corpo da vítima, se distribuindo parcialmente pelo interior do corpo e parcialmente pela superfície do mesmo. Outras variantes de descargas diretas são enumeradas abaixo:

1. Descargas laterais - Ocorre quando o raio incide sobre objetos elevados (por exemplo, uma árvore) e em seu percurso para o solo a corrente de retorno pode procurar caminhos de menor impedância, muitas vezes pelo estabelecimento de arcos no ar, que conectam objetos de boa condutividade em contato com o solo; Caso mais freqüente dos acidentes, principalmente pelas pessoas procurarem, durante tempestades, se abrigar debaixo de árvores;

2. Descargas por contato - A descarga por contato ocorre quando a vítima está em contato com um corpo que se tornou um caminho de eventual corrente de descarga, no percurso desta para o solo. Semelhante à descarga lateral, sendo que como o nome sugere, deve haver uma ligação física entre eles para ser caracterizado como tal;

3. Descargas para múltiplos pontos - Ocorre quando a descarga, em sua proximidade com a terra, incide sobre múltiplos pontos, incluindo descargas diretas e descargas laterais, figura 3.02;

4. Acidentes por tensão de passo - Ao incidir em estruturas elevadas, ou diretamente no solo, a corrente de descarga é injetada neste meio, sendo ali dispersada. Durante esta dispersão, a corrente promove uma elevação de potencial no solo, estabelecendo uma distribuição de potenciais na superfície deste, que podem ser submetidas a pessoas e animais nas proximidades do ponto de impacto. 
5. Acidentes "internos" - Ocorrem quando do impacto de um raio nas proximidades de uma LT, ou mesmo sobre ela, induz sobre correntes que viajam pela LT e entram nos sistemas de energia residenciais. Nestes casos, a pessoa pode sofrer uma descarga pelo simples fato de estar segurando algum equipamento ligado ao sistema de energia da residência.

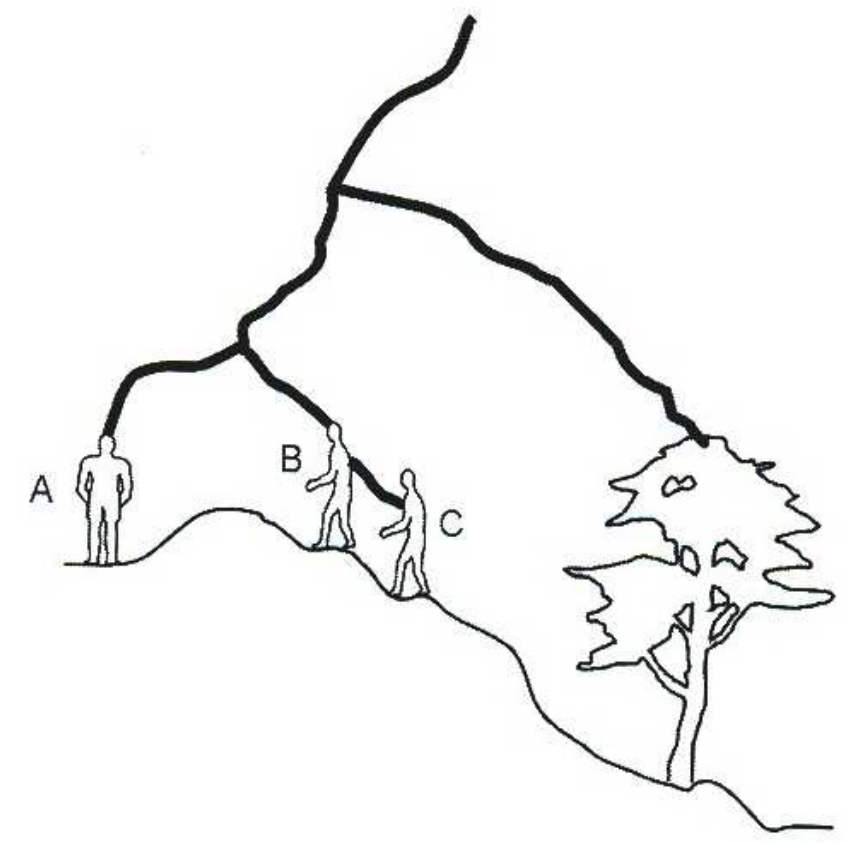

Figura 3.02 Descarga para múltiplos pontos [06]

Os efeitos de maior severidade acontecem através das descargas diretas. As descargas diretas acontecem quando o canal principal (ou um dos ramos deste canal) incide diretamente sobre determinado objeto. Neste caso, se ele cair sobre edificações de alvenaria, por exemplo, poderá destruir paredes, fundir telhas de metal, destruir antenas e cabos de comunicações, etc. Lembrando que para materiais feitos à base de alumínio e cobre, como é o caso dos cabos de comunicação e antenas residenciais, o ponto de fusão deste material é relativamente muito baixo (na ordem de $660^{\circ} \mathrm{C}$. Em países de clima temperado, onde a maioria das residências é feita de madeira, muitos incêndios são causados por descargas diretas - principalmente devido ao alto nível de combustão da madeira local. 


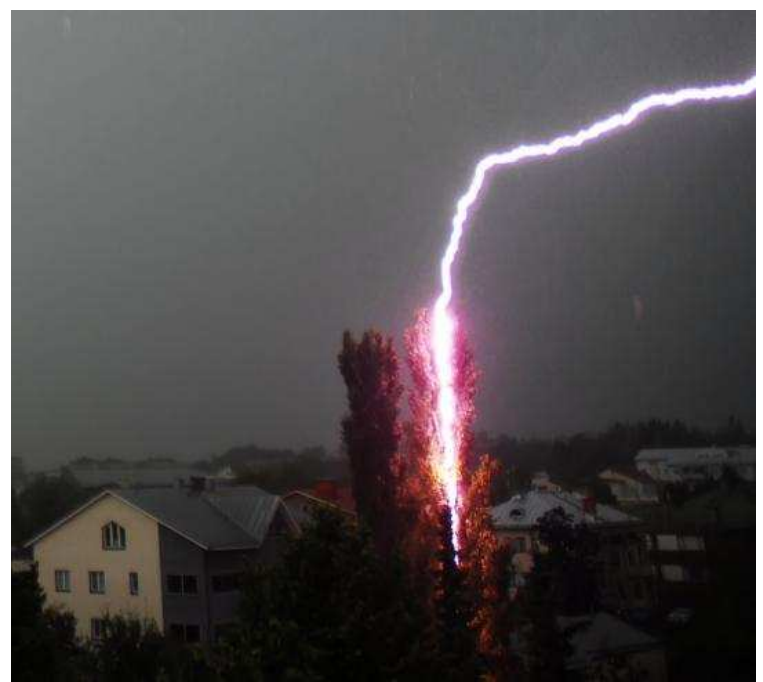

Figura 3.03 Registro de uma descarga direta sobre uma árvore [34]

No caso de árvores, se atingidas pelo canal principal, elas podem ficar petrificadas devido a elevada intensidade da corrente, da altíssima temperatura e da rápida evaporação da água em seus corpos, ou podem queimar no caso de atingidas por algum ramo [06].

O corpo humano tem uma ordem de grandeza da impedância estimada na faixa de 300 a $600 \Omega$. Ao atingir um indivíduo, cuja impedância fosse de $500 \Omega$, considerando-se um pulso de 0,5s por exemplo, a corrente de descarga seria capaz de transferir-lhe aproximadamente $2,5.10^{4} \mathrm{~kJ}$. Ou seja, dissiparia sobre este desafortunado indivíduo uma potência média de $50.000 \mathrm{~kW}\left(2,5.10^{4} \mathrm{~kJ} / 0,5 \mathrm{~s}\right)$. Considerando, para efeito de comparação, que um chuveiro elétrico tem em média $4,5 \mathrm{~kW}$, ser atingido diretamente por um raio significaria sofrer as conseqüências de uma potência 10.000 vezes maior.

Uma curiosidade interessante: Durante a Idade Média na Europa, acreditava-se que carregar pedras de raio garantiria proteção contra raios, visto que era crença comum de que um raio não caia duas vezes no mesmo lugar. As pedras de raio eram o resultado da vitrificação da areia quando submetidas ao intenso calor produzido por uma descarga direta.

\subsection{1 - Situações de risco por exposição}

É possível identificar algumas situações muito comuns de exposição em momentos de tempestades, consideradas de risco quanto à incidência de descargas. Situações, como as descritas abaixo, devem ser evitadas. 
- Campos abertos, áreas planas, praias, margens de rio;

- Alto de montanhas ou colinas;

- Cavalgar ou andar de moto/bicicleta;

- Em rio, dentro de pequenas embarcações ou nadando;

- No mar, dentro de pequenas embarcações ou nadando;

- Árvores isoladas; tocar ou estar próximo de qualquer árvore;

- Portar objetos elevados (como vara de pescar);

Ao analisar estas situações, pode-se perceber que o perigo está em se posicionar em destaque, como uma "estrutura" superior em relação às demais, e assim, tornando-se um ponto preferencial de incidência de descarga.

Quando se ouve falar que alguém sobreviveu a um raio, muito provavelmente tratase de algum ramo do canal principal. Ainda assim, os resultados mais comuns são:

- Queimaduras: Por arco ou por lampejo, se o trajeto do raio não atravessa o corpo; por efeito Joule devido a passagem da corrente pelo corpo.

- Sistema Nervoso: A passagem da corrente a nível encefálico, pode ter por seqüelas freqüentes hemiplegia, atrofia cortical, síndrome extrapiramidal, lesões medulares relacionadas a passagem da corrente pela medula espinhal, lesões de nervos periféricos com distúrbios sensitivos e motores.

- Sistema Cardiovascular: A parada pode ocorrer por assistolia ou fibrilação ventricular.

- Sistema Respiratório: Ruptura brônquica ou pleural por efeito direto, lesão da membrana alvéolo-capilar devido a explosão por ar superaquecido.

- Neurosensorial: Descolamento de retina e catarata, ruptura timpânica, distúrbios do equilíbrio (por labirintite).

- Muscular: lesão muscular extensa no trajeto da corrente, com necrose profunda e rabdomiólise.

- Renal: Tubulopatia; trombose arterial e lesão traumática.

- Cutânea: Queimaduras de vários graus, em particular nos pontos de entrada e nos locais de contato com peças metálicas (como o material de escalada). 
O parâmetro "valor de pico da corrente de descarga" influencia na definição do nível de sobretensão resultante em sistemas atingidos. Quando o condutor de uma linha de transmissão é atingido por uma descarga, a corrente de pico, que no Brasil costuma ser da ordem de $40 \mathrm{kA}$, é dividida em duas partas, sendo que cada parte se dirige num sentido da linha de transmissão. Mesmo dividida, considerando uma impedância de $300 \Omega$ para a LT, significa surgir uma onda de sobretensão da ordem de $6 \mathrm{MV}(40 \mathrm{kA} / 2 * 300 \Omega)$, conforme figura abaixo.

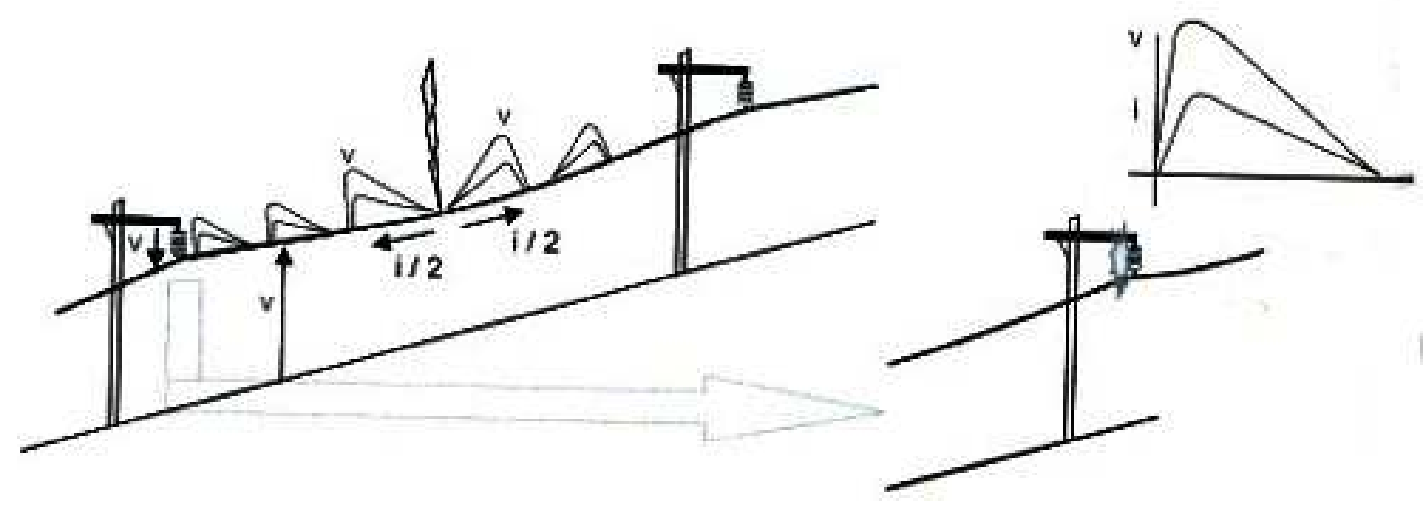

Figura 3.04 Onda de sobretensão devido a descarga direta na LT [06]

Em outras palavras, logo que a onda de sobretensão alcança a $1^{\mathrm{a}}$ torre metálica, o isolador que separa o condutor energizado da torre (eletricamente conectada ao solo), fica submetido a uma sobretensão capaz de romper esse isolamento através de um arco elétrico, fechando o circuito Linha de Transmissão - Torre. A partir desse cenário, se a torre não tiver um bom aterramento, a corrente de descarga flui para a terra estabelecendo no solo, uma elevação de potencial em relação a pontos distantes (terra remoto). Tal elevação de potencial estabelece uma distribuição de potenciais na superfície do solo, propiciando as condições necessárias para acidentes envolvendo tensões de passo.

\section{3 - Descargas Indiretas}

As descargas indiretas, que são o foco deste trabalho, são aquelas causadas sobre as estruturas e seres vivos a partir de determinada distância do ponto de queda. Apesar de as descargas diretas terem um alto poder destrutivo, as estatísticas mostram que esse tipo de evento é muito reduzido quando comparado com descargas indiretas. 
Quando ocorre a corrente de retorno, ou seja, o líder em sentido ascendente se encontra com o líder descendente, e fecham o circuito, surge uma descarga de grande intensidade, produzindo elevação de temperatura no centro do canal ionizante, provocando a rápida expansão do ar, grande luminosidade e fortes campos eletromagnéticos em torno desse canal principal; no chão, a partir do ponto de impacto, linhas de corrente se propagam também no sentido radial, sujeitando a vizinhança a sofrer tensão de passo, tensão de toque, EMI e tensões induzidas em corpos condutores próximos.
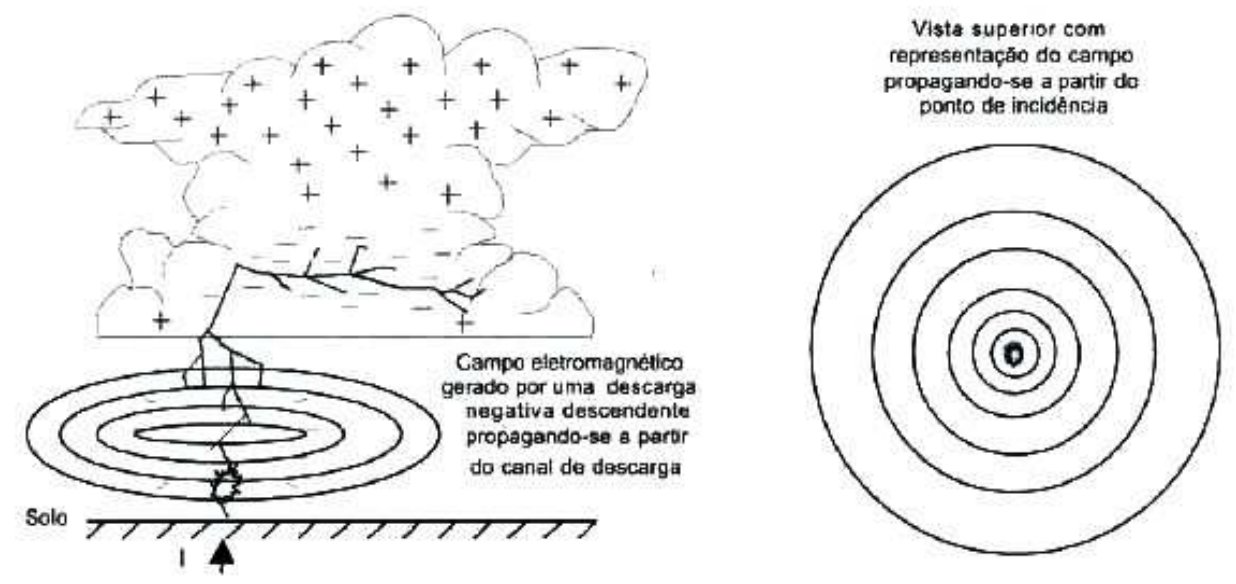

Figura 3.05 Onda eletromagnética irradiada pela corrente de retorno [06]

Estes efeitos decorrentes da incidência do campo eletromagnético gerado pela descarga têm sua intensidade condicionada pela taxa de crescimento da corrente de retorno na frente de onda ou pelos dois parâmetros associados: o valor de pico da corrente e seu tempo de frente de onda.

Embora os efeitos de irradiação gerados por campos eletromagnéticos possam causar danos aos seres humanos, estes danos costumam se restringir a equipamentos eletrônicos sensíveis (EES) e sistemas de comunicações. Nestes, tais efeitos podem constituir fonte de corrupção dos dados transmitidos.

\subsection{1 - Tensões Induzidas}

A indutância é a propriedade que um condutor tem de armazenar energia em um campo magnético; a quantidade de energia armazenada depende da corrente que passa pelo condutor. Se tivermos um condutor singelo de raio muito pequeno, conduzindo uma 
corrente $\boldsymbol{i}$, como mostrado na figura abaixo, o campo magnético a uma distância $\boldsymbol{r}$ do condutor será diretamente proporcional à corrente $i$ e inversamente proporcional à distância $\boldsymbol{r}$.

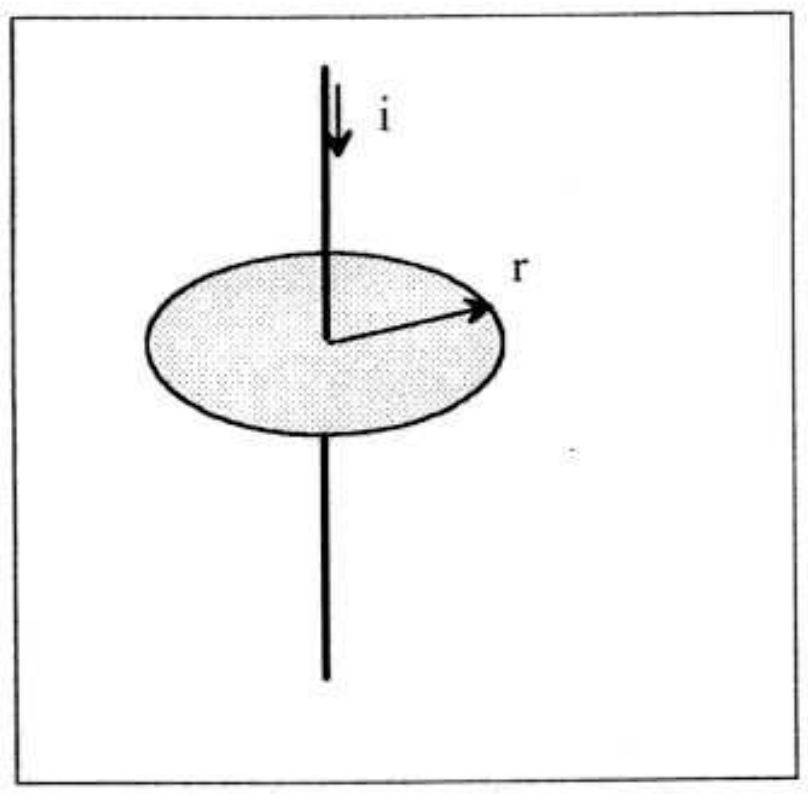

Figura 3.06 Corrente induzida [02]

Sendo a corrente $\boldsymbol{i}$ dada em ampères, a permeabilidade do meio $(\boldsymbol{\mu})$ dada em Henry/metro (para o ar vale 1,0) e a distância $\boldsymbol{r}$ em metros, resulta uma densidade de fluxo $\boldsymbol{B}$ em weber $/ \mathrm{m}^{2}$ que pode ser calculada por:

$$
B=\frac{\mu . i}{2 . \pi . r} \quad\left[W b / m^{2}\right]
$$

E a indutância, definida como a relação entre o fluxo e a corrente $\boldsymbol{i}$, será:

$$
L=\frac{\phi}{i}=\frac{\mu}{2 \cdot \pi} \cdot \ln \frac{R}{r_{1}}
$$

Para os condutores de seção circular mais usados nas instalações de proteção (como captores, cabos de descida ou aterramento), as indutâncias são aquelas dadas na tabela abaixo: 
Tabela 3.03 Espessura média dos cabos de descida [04]

\begin{tabular}{|c|c|}
\hline $\begin{array}{c}\text { Condutor } \\
\left(\mathrm{mm}^{2}\right)\end{array}$ & $\begin{array}{c}\text { Indutância } \\
(\mu \mathrm{H} / \mathrm{m})\end{array}$ \\
\hline 16 & 1,21 \\
\hline 35 & 1,13 \\
\hline 50 & 1,09 \\
\hline 70 & 1,06 \\
\hline 95 & 1,02 \\
\hline
\end{tabular}

De acordo com estes dados, verificamos que aumentando a seção do condutor, sua indutância diminui, apesar de sempre ficar em torno de $1,1 \mu \mathrm{H} / \mathrm{m}$, independente do material utilizado. No entanto, é possível reduzir este valor ao utilizar barras chatas ou fitas ao invés dos condutores circulares. Isto porque a indutância será tanto menor quanto maior for a relação entre largura e espessura. Para a mesma quantidade de material, a indutância de uma chapa é muito menor que a de um cabo.

Para que haja passagem de corrente por um condutor é necessário a existência de uma tensão que vença a indutância deste condutor. Ao ser atingido por um raio, aparecerá entre os terminais deste condutor uma tensão que imporá a passagem de uma corrente com uma taxa de $\boldsymbol{d i} / \boldsymbol{d} \boldsymbol{t}$. Considerando que a corrente de um raio tem uma taxa $\boldsymbol{d i} / \boldsymbol{d} \boldsymbol{t}$ da ordem de dezenas de $\mathrm{kA} / \mu$ s e que as indutâncias dos condutores de descida são da ordem de 2,5 $\mu \mathrm{H} / \mathrm{m}$, as tensões indutivas geradas serão da ordem de dezenas de $\mathrm{kV} / \mathrm{m}$.

As taxas de crescimento da corrente de projeto para os diversos níveis de proteção (conforme será visto no capítulo 4), de acordo com a IEC, são de $100 \mathrm{kA} / \mu$ s para os níveis III e IV, $150 \mathrm{kA} / \mu$ s para o nível II e $200 \mathrm{kA} / \mu$ s para o nível I.

Considere o seguinte exemplo: Construção Nível III, com $10 \mathrm{~m}$ de altura, dois captores e dois cabos de descida com seção de $35 \mathrm{~mm}^{2}$. Sem interligação dos captores, teríamos tensões na ordem $113 \mathrm{kV} / \mathrm{m}$, conforme tabela abaixo.

Tabela 3.04 Tensão total em função da seção transversal do cabo de descida [04]

\begin{tabular}{|c|c|c|c|c|}
\hline Condutor & Indutância & di $/ \mathbf{d t}$ & V unit. & V total \\
\hline $35 \mathrm{~mm}^{2}$ & $\mathbf{1 , 1 3} \mu \mathrm{H} / \mathrm{m}$ & $100 \mathrm{kA} / \mu \mathrm{s}$ & $113 \mathrm{kV} / \mathrm{m}$ & $1130 \mathrm{kV}$ \\
\hline
\end{tabular}

Poderia surgir a pergunta: mas qual a importância de se saber estes dados? Como este trabalho trata das consequiências de uma descarga atmosférica sobre uma antena de 
TV, seja esta descarga direta ou indireta, haverá uma indução no cabo de comunicação ligado à antena, que não reagirá diante desta corrente da mesma forma que um cabo de descida especificamente criado para esse fim.

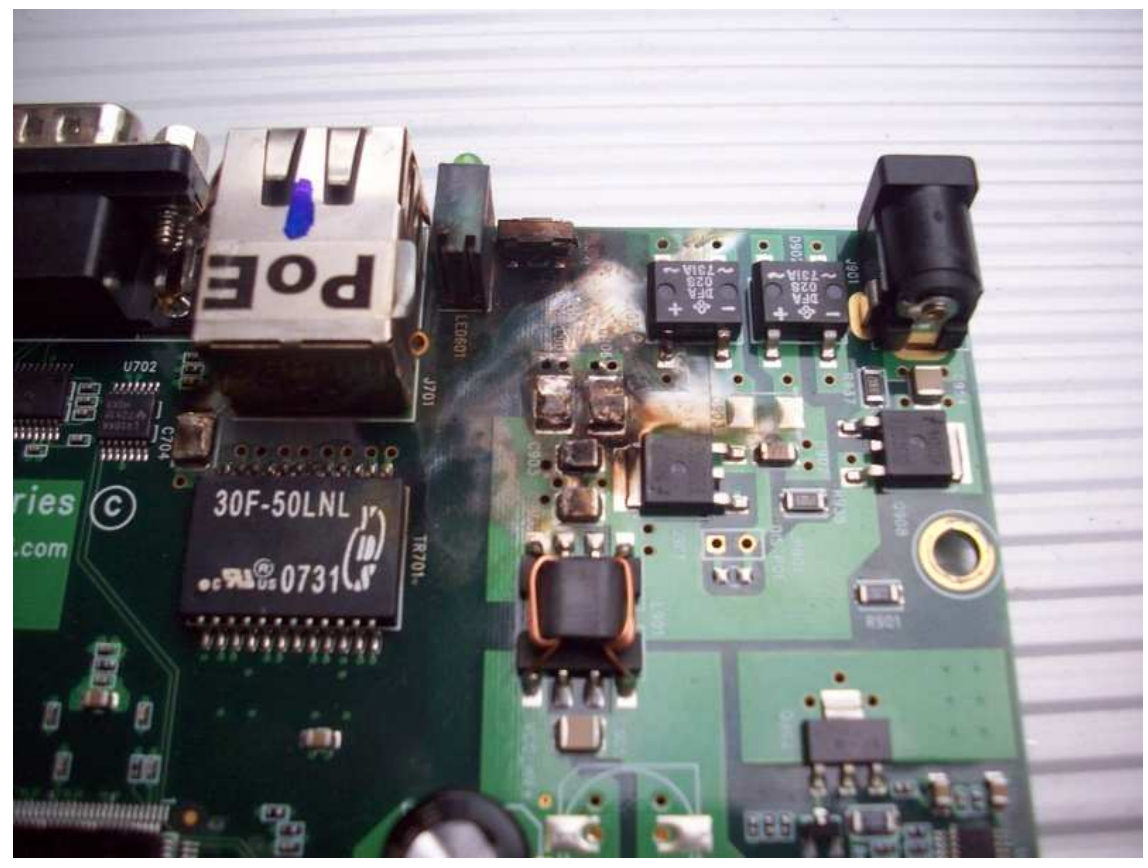

Figura 3.06 Placa de rádio PABX queimado após descarga sobre antena não aterrada [38]

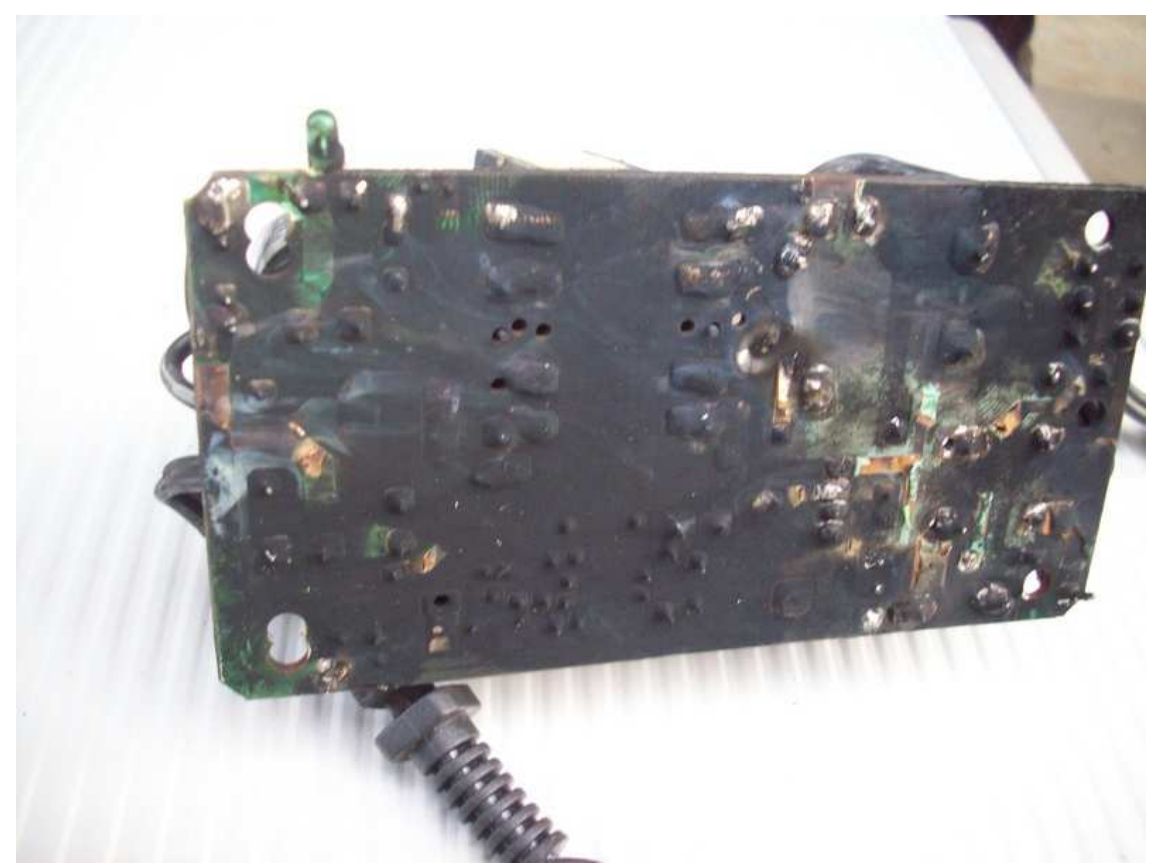

Figura 3.07 Placa de rádio PABX queimado após descarga sobre antena não aterrada [38] 


\subsubsection{1 - Captor Natural}

A NBR 5419/2005, em seu parágrafo 5.1.1.4, um captores natural pode ser definido como qualquer elemento que do ponto de vista físico possa ser atingido pelos raios.

Ou seja, a questão quanto a capacidade de uma antena de atrair raios ou não está ligado diretamente às semelhanças desta com um sistema de pára-raios tipo Franklin (que será abordado mais adiante). Tanto é que a norma complementa este parágrafo dizendo que todo captor natural deve ser ligado ao SPDA. No entanto, o que se constata no dia-a-dia é o descumprimento desta diretriz, seja por falta de conhecimento, seja por negligência.

Uma antena, para poder cumprir eficientemente com sua tarefa de captação de sinais, deve ser elevada a uma posição de destaque na construção. Normalmente, colocada sobre o telhado da estrutura, ela passa a se comportar (assume as características) como um captor do tipo Franklin. Mas as semelhanças não param por aí visto que o cabo de comunicação que liga a antena à TV passa a se comportar como um cabo de descida (subsistema de um SPDA). No entanto, diferente de um verdadeiro SPDA, este não tem aterramento e a corrente que vier a descer pelo cabo de comunicação não encontrará um caminho de escape para a terra.

Tabela 3.05 Comparação entre SPDA e Sistema antena de TV

\begin{tabular}{|c|c|}
\hline Pára-raios Franklin & Antena de TV \\
\hline Captor colocado em destaque na estrutura & Colocado em destaque na estrutura \\
\hline Cabo de descida por fora da estrutura & Cabo externo ligando a antena ao televisor \\
\hline Sistema de aterramento & Rede elétrica da residência \\
\hline
\end{tabular}

Como dito anteriormente, após o fechamento do circuito nuvem-terra, a corrente de retorno que flui pelo canal ionizado, criado para transferência de carga durante o estabelecimento da descarga atmosférica, promove tensões induzidas em corpos próximos (ou não) ao ponto de incidência. Tais tensões constituem a principal fonte de danos nas linhas de distribuição de energia em circuitos de baixa tensão em geral, incluindo as redes de telecomunicações. Constituem ainda a origem de interferência eletromagnética em sistemas e equipamentos, que em muitos casos, resulta na perda dos dados transmitidos/recebidos.

Em tempestades de chuvas, é freqüente a queima de transformadores nos sistemas de distribuição e danos em equipamentos sensíveis de unidades consumidoras. Tais danos 
são usualmente causados por surtos de tensão, associados à tensão induzida por descargas, introduzidas através dos condutores dos sistemas de comunicação, e redes de energia. No caso das descargas atmosféricas as tensões de impulso podem ser geradas:

- Na rede telefônica externa à edificação por meio de indução;

- Na rede de televisão externa por meio de indução;

- Na fiação interna da edificação através da rede de alimentação.

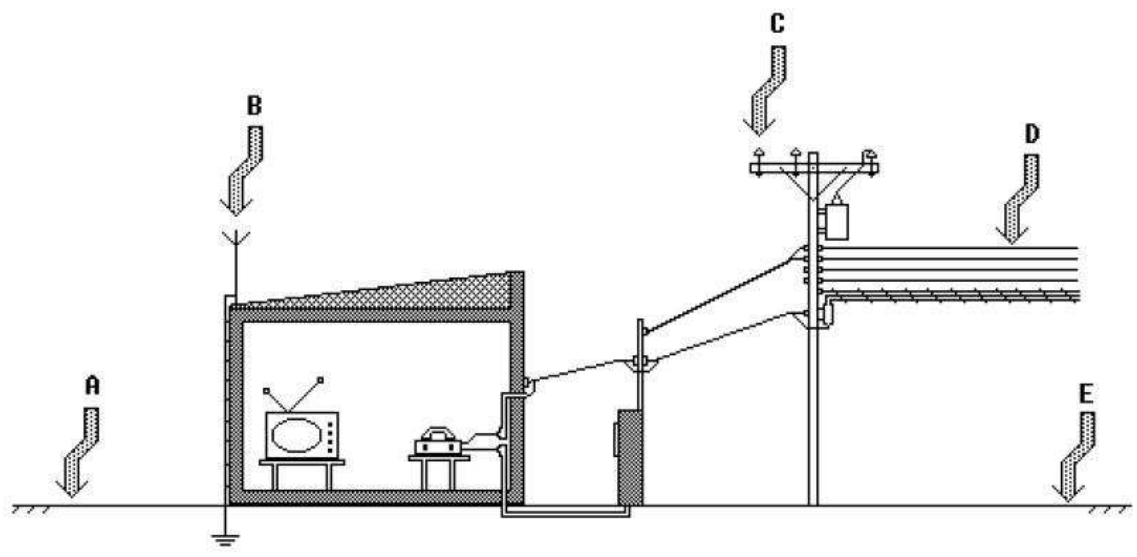

Figura 3.08 Formas de incidência de tensão indusida [23]
A - Perto da edificação
B - No pára-raios
$\mathrm{C}$ - Na rede de Alta Tensão
D - Na rede de Baixa Tensão
E - Perto das redes elétrica e de telefone

A figura 3.08 apresenta 5 formas de interação de uma descarga atmosférica com uma edificação. Nos casos dos eventos "A" e "B" os campos eletromagnéticos criados pela descarga irão atingir a fiação das redes existentes dentro da edificação, por meio de tensões induzidas e atingirão os terminais dos equipamentos. Estas sobretensões geradas na rede externa dependem de uma série de fatores:

- Grau de exposição das redes elétricas e telefônicas;

- Comprimento das redes;

- Tipo de cabo utilizado;

- Resistividade do solo;

- Sistema de aterramento,

Etc. 
Nos casos dos eventos "C", "D" e "E", as sobretensões irão atingir os equipamentos através da fiação externa das redes de energia elétrica e telefônica, seja por descarga direta ou indireta sobre as linhas.

A determinação dos valores das sobretensões e sobrecorrentes que atingem um equipamento terminal pode ser feita por meio de simulações computacionais ou de medições realizadas em instalações reais.

Além dessas 5 configurações, podemos citar uma $6^{\text {a }}$ configuração que seria justamente a presença de uma antena de TV externa e não aterrada. Uma antena de TV externa está sujeita a dois tipos de situações: na $1^{\mathrm{a}}$, devido a uma descarga direta sobre a antena, a corrente percorreria o cabo de comunicação ligado à antena, em direção ao terra. Como não há ligação do sistema de aterramento central com a antena (nem com a blindagem do cabo), essa corrente atingiria todos os aparelhos ligados aos terminais do cabo. A $2^{\mathrm{a}}$ situação seria através de tensões induzidas na rede de baixa tensão, e entrando (da mesma forma que para o caso do telefone) na rede elétrica interna da construção. Para ambos os casos, se uma pessoa estiver tocando ou segurando algum aparelho ligado à rede elétrica, poderá sofrer os efeitos de uma tensão de toque.

\subsubsection{2 - Os cabos de comunicação}

Atualmente, é comum o uso do mesmo (ou senão o mesmo, do mesmo tipo) tipo de cabos tanto para comunicação quanto para telefone (Como os utilizados para TV a cabo, por exemplo). O conhecimento deste tipo de cabo é muito importante quando se trata de descargas, devido ao risco de tensões induzidas, transmitindo sobretensão geradas na rede externa, eventualmente atingindo os equipamentos.

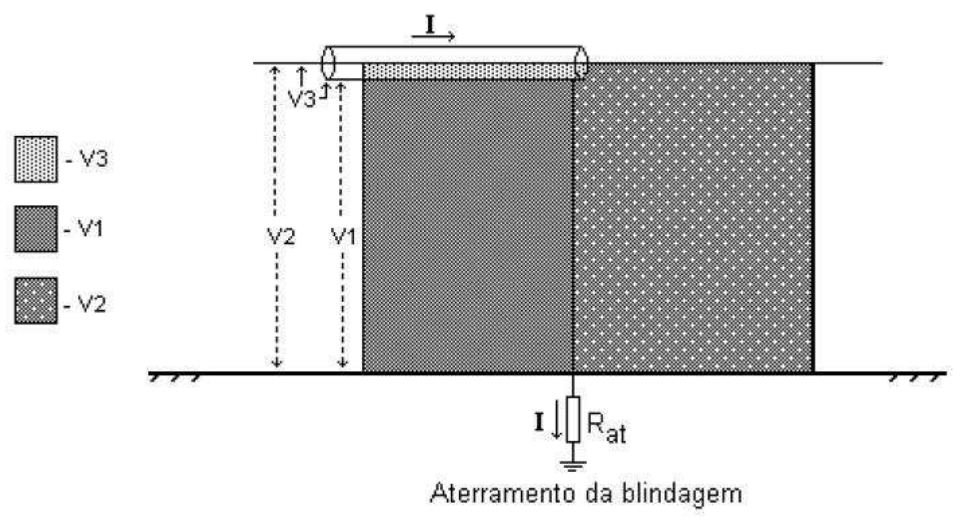

Figura 3.09 Tensões sobre um cabo coaxial [23] 
A figura 3.09 ilustra as tensões dentro de um cabo coaxial, onde:

I - Corrente que circula na blindagem do cabo;

$\mathrm{V}_{1}$ - Tensão da blindagem para a terra;

$\mathrm{V}_{2}$ - Tensão do fio para a terra;

V3 - Tensão entre o fio e a blindagem;

$\mathrm{R}_{\mathrm{cc}}-$ Resistência da blindagem do cabo;

$\mathrm{R}_{\mathrm{at}}-$ Resistência de aterramento da blindagem.

$\mathrm{V}_{1}=\mathrm{R}_{\mathrm{at}} . \mathrm{I}$;

$\mathrm{V}_{3} \approx \mathrm{R}$ cc. $\mathrm{I}$

$\mathrm{V}_{2}=\mathrm{V}_{1}+\mathrm{V}_{3}$

$\mathrm{V}_{3}<<\mathrm{V}_{1}$

$\mathrm{V}_{2} \approx \mathrm{V}_{1}$.

É importante observar que a tensão " $\mathrm{V}_{1}$ " que aparece da blindagem para a terra, é a soma da queda de tensão no cabo, que interliga a blindagem à malha de aterramento, com a queda de tensão que ocorre na malha de aterramento. A queda de tensão na malha, na maioria das vezes, é bem superior à queda de tensão no cabo (figura abaixo).

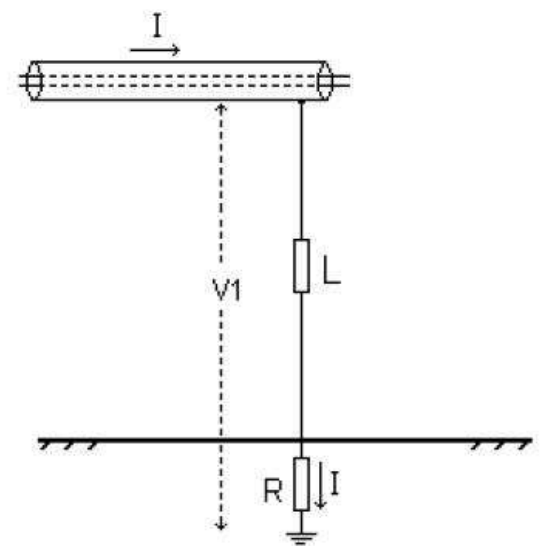

$$
V_{1}=R . I+L \cdot \frac{d I}{d t} ; \quad L-\text { Indutância do cabo }
$$

Figura 3.10 Blindagem de um cabo coaxial [23] 
A figura anterior mostra que a partir do conhecimento das tensões que aparecem da blindagem do cabo para a terra é possível estimar as tensões que aparecem dos pares para a terra.

Como pode ser visto na figura 1 , descargas atmosféricas que incidem na própria rede telefônica ou próximo dela irão impor tensões elevadas que poderão chegar até os equipamentos. As descargas diretas na rede geralmente provocam um grande dano no local do impacto, levando na maioria das vezes à ruptura do cabo. As tensões induzidas por descargas próximas da rede são de menor valor que as provocadas pelas descargas diretas mas em compensação a sua ocorrência é muito mais freqüente.

Como visto na figura acima, a partir do conhecimento da tensão blindagem-terra é possível estimar o valor da tensão par-terra. Isto significa que pode-se calcular apenas as tensões induzidas da blindagem do cabo para a terra.

\subsubsection{3 - Outros efeitos causados por sobretensão}

- Tensão de passo: um ser vivo, com os apoios (pés ou patas) separados, fica sujeito a uma tensão que provocará a circulação de corrente pelo tronco. Nos bípedes isto raramente causa a morte, pois a parcela da corrente que passa pelo coração é muito pequena; já para os quadrúpedes, a totalidade da corrente passa pelo tronco e é a causa mais freqüente de morte durante as tempestades.

- Tensão de toque: quando o condutor da corrente do raio tem uma alta impedância, são geradas tensões ao longo dele, e uma pessoa que toque ficará sujeita a uma tensão que, aplicada entre uma ou as duas mãos e os pés, provocará a passagem de corrente pelo tronco, causando freqüentemente a morte. É possível também que a causa da corrente seja o campo magnético no laço formado entre a pessoa e condutor.

- Descarga lateral: em uma situação parecida com a anterior, entre o condutor da corrente e a cabeça da vítima aparece uma tensão tão alta que ocorre uma descarga disruptiva, causando freqüentemente a morte. Esta é a causa mais comum de morte pois as pessoas procuram se abrigar da chuva embaixo das 
árvores e são atingidas pelas descargas, ou sofrem os efeitos dos campos magnéticos no laço formado entre elas e a árvore.

- Descarga direta: uma pessoa andando em campo aberto pode se tornar o alvo e receber diretamente o impacto do raio, caso em que raramente resiste às queimaduras e aos efeitos da corrente sobre o cérebro e o coração. Os poucos sobreviventes são as vítimas que foram atingidas por um ramo ou braço menor do raio, com corrente de baixa intensidade.

\subsection{2 - Interferência eletromagnética}

As condições a que um equipamento eletroeletrônico está submetido podem ser agrupadas em 3 classes principais: mecânicas (vibrações, choques, etc.), ambientais (temperatura, umidade, etc.) e elétricas (oscilações na fonte, ruído, etc.). todos estes fatores combinados afetam o desempenho do equipamento. Dentre estas condições, uma muito importante a qual deve ser considerada em todas as fases da vida do equipamento (projeto, testes, utilização e manutenção), é a condição elétrica da interferência eletromagnética. [09]

Interferência eletromagnética (EMI) é o nome genérico dado a toda energia eletromagnética, que cause resposta indesejável (ruído elétrico), sem considerar o ruído inerente ao próprio componente (tais como o ruído: térmico, shot, recombinação), a qual pode ser gerada por centelhamento nas escovas de motores, chaveamento de circuitos de potência, lâmpadas fluorescentes, descargas atmosféricas, descargas eletrostáticas, entre outros.

A interferência eletromagnética é muito importante, principalmente em sistemas digitais e sistemas analógicos que envolvam sinais de frequiências superiores a VHF (30 a300MHz); pois em virtude de estarem envolvidos pulsos com tempo de transição da ordem de nanosegundos, irradiação de sinais, acoplamentos parasitas, etc.; toda trilha na placa de circuitos impresso pode transformar-se em uma antena de transmissão e recepção de ruídos.

A interferência eletromagnética provoca a aceleração da degeneração dos circuitos integrados devido aos transientes e surtos de tensão e corrente provocados no equipamento influenciado; degradação do desempenho de um equipamento, canal de transmissão ou 
sistema. A atenuação/eliminação da interferência eletromagnética prolonga a vida do equipamento.

\subsubsection{1 - Fontes de EMI e sistemas de proteção}

Problemas com EMI (ou melhor, equipamentos sensíveis a Interferências Eletromagnéticas) tendem a aparecer desde o nível do microchip, passando pela placa de circuitos e até a própria caixa que aloja o equipamento. No nível do chip, os fabricantes costumam se encarregar de fornecerem seus equipamentos com os devidos recursos que possibilitem a redução dos problemas com EMI. No entanto, empresas que venham a utilizar este chip em suas placas de circuito não têm a mesma preocupação. [39]

Uma simples trilha na placa de circuito mal planejada pode funcionar como uma antena, tanto captando quanto transmitindo interferências. A indutância associada a uma curva numa trilha juntamente com as capacitâncias parasitas do circuito, podem fazer com que ela ressoe em freqüências indesejadas.

A origem de uma EMI pode ser dividida em duas formas principais:

- EMI externas - quando um agente externo, tal como descargas atmosféricas, radiações solares, entre outras fontes naturais, gera interferência sobre EES em outro;

- EMI internas - quando partes de um sistema interfere em outras partes deste mesmo sistema ou de outros. Podemos citar como exemplo o liquidificador gerando perturbação no sinal da televisão, reatores de lâmpadas fluorescentes gerando harmônicos na rede, etc.

Algumas descargas atmosféricas podem apresentar valores próximos da interferência eletromagnética de um EMP (Pulso Eletromagnético) gerado por uma explosão nuclear (campo elétrico da ordem de $10^{5} \mathrm{~V} / \mathrm{m}$ e campo magnético da ordem de $260 \mathrm{~A} / \mathrm{m}$, com largura de pulso de $20 \mathrm{~ns}$ e tempo de subida da ordem de $5 \mathrm{kV} / \mathrm{ns}$ ). [09] 


\section{PROTEÇÃO EXTERNA}

Foram apontados vários efeitos danosos das descargas atmosféricas. Neste capítulo serão discutidos as formas ou sistemas para a proteção contra tais efeitos, podendo até mensurar o quanto de imunidade aos raios pode-se obter.

Será comentado as diferentes filosofias dos SPDA, e deixando para o próximo capítulo comentários sobre os sistemas de proteção interna.

O principal objetivo de um SPDA é evitar a incidência direta de raios sobre as estruturas a proteger, através de pontos de referência para as descargas que eventualmente possam vir a atingir a estrutura. Para ter sucesso, além de captar a eventual descarga, o SPDA deve ser capaz de direcionar o fluxo de corrente diretamente ao solo, seguindo o percurso mais fácil possível (ou seja, o mais curto e de menor resistência).

Ao se planejar proteger dada estrutura, devemos identificar características que possam vir a contribuir ou a exigir proteção:

- Deve-se identificar o tipo de área a ser protegida: se um prédio, um galpão, um parque, uma residência, etc..

- Deve-se verificar o uso e o tipo de construção a que se destina: se tem trânsito constante de pessoas, armazena produtos químicos inflamáveis, etc.

O dimensionamento de um SPDA começa a partir do conhecimento dessas características.

Como dito, a determinação da queda de um raio é uma questão de probabilidades. É interessante calcular a probabilidade de um raio cair numa dada estrutura a partir do nível de incidência. No entanto, para um país como o Brasil, que como já dito é o campeão mundial de incidência de raios [36], somente em casos bem particulares deveriam dispensar a proteção. Isto porque o cálculo desenvolvido para se estimar a probabilidade de queda foi desenvolvido, tendo como banco de dados, estatísticas européias, que nem de perto se assemelham às características elétrico-ambientais de nossa nação.

A NBR 5419/2005 estabelece duas regras a serem seguidas quanto à necessidade de uso de SPDA. A $1^{\text {a }}$ diz respeito à avaliação do risco da edificação ser atingida por uma 
descarga atmosférica (que como dito anteriormente, é baseada em normas estrangeiras); $\mathrm{Na}$ $2^{\mathrm{a}}$ ela estabelece quatro níveis (classificações) de proteção, conforme o risco, o tipo, e a finalidade da estrutura a proteger.

Uma vez tomada a decisão de se instalar um sistema de proteção, devemos saber que por mais completo que o sistema seja, ele não garantirá $100 \%$ de segurança. As normas internacionais classificam a necessidade de algo ser protegido de formas diferentes umas das outras:

- BS 6651 e NFPA 780 consideram dois tipos de proteção correspondentes a estruturas comuns e estruturas perigosas (BS - Norma Britânica e NFPA Norma Norte-Americana);

- VDE 0185 considera três tipos de proteção correspondentes a comuns, perigosas e muito perigosas (VDE - Norma Alemã);

- IEC considera quatro tipos correspondentes a baixo risco, risco normal, risco elevado e risco muito elevado.

Uma particularidade quanto à norma alemã é que com a criação da União Européia, decidiu-se por tornar a IEC como norma padrão; desse modo, não só as norma alemã, como as normas dos demais membros da União Européia tem de se ajustar ao padrão IEC [04].

A NBR 5419/2005 segue a linha da IEC classificando os níveis de periculosidade em 4 tipos:

- Nível I - Destinado às estruturas nas quais uma falha do sistema de proteção possa causar danos às estruturas vizinhas ou ao meio ambiente: depósitos de explosivos, de produtos tóxicos ou radioativos, etc.

- Nível II - Destinado às estruturas cujos danos em caso de falha serão elevados ou haverá destruição de bens insubstituíveis e(ou) valor histórico: museus, sítios arqueológicos, ginásios de esportes, etc.

- Nível III - Destinado às estruturas de uso comum: residências, escritórios, escolas, fábricas, etc. exceto àqueles com área classificada (como veremos adiante); 
- Nível IV - Destinado às estruturas construídas de material pouco inflamável, com pouco acesso de pessoas e conteúdo não inflamável: depósitos de concreto armado, estruturas metálicas de produtos não inflamáveis, etc.

Pela descrição desses níveis, verifica-se que haverá casos em que será desnecessário fazer qualquer cálculo, pois o risco é tão grande que será obrigatório a instalação de um SPDA no nível mais elevado possível. Por outro lado, pode haver a conclusão de que devido às características de relevo e utilidade, a proteção seja dispensável.

As áreas classificadas são aquelas em que há vapores, gases, pós ou fibras em concentração, temperaturas e umidade tais que com uma faísca ou uma quantidade de energia acima de dado ponto cause incêndios e(ou) explosões. Para estes casos, o uso de um SPDA é obrigatório.

Para que haja uma reação numa mistura (gás-ar ou vapor-ar) é necessário que certos acontecimentos ocorram simultaneamente:

- A concentração da mistura esteja na proporção correta para haver inflamação;

- Haja faíscas com energia suficiente para iniciar a inflamação da mistura ou elevação da temperatura acima de um dado valor.

As áreas de risco de explosões ou de inflamação são denominadas pelas normas internacionais e brasileiras de áreas classificadas, sendo que sua classificação é feita baseada na probabilidade das condições necessárias para uma explosão ou inflamação ocorrerem.

Dessa forma, a norma brasileira define as diferentes zonas da seguinte forma:

- Zona 0 - Gases, vapores continuamente em condições de inflamação;

- Zona I - Gases e vapores periodicamente em condições de inflamação;

- Zona II - Gases e vapores esporadicamente em condições de inflamação (casos de acidentes ou falhas de manutenção);

- Zona 10 - Pós e fibras continuamente em condições de inflamação;

- Zona 11 - Pós e fibras em condições de inflamação por períodos curtos. 
O conhecimento dessas informações é importante no momento que empresas montam sistemas de combate a incêndio. Por exemplo, na "Zona 0" não podem ser usados equipamentos elétricos, salvo circuitos de sinalização ou de controle com "proteção intrínseca”, garantindo que em casos de defeito destes equipamentos, as possíveis faíscas produzidas sejam insuficientes para iniciar uma reação.

\section{1 - Níveis de proteção}

O nível de proteção não está relacionado com a probabilidade de queda do raio na edificação, mas com a eficiência que o sistema tem de captar e conduzir o raio à terra. Dito isto, há quatro níveis de proteção que o projetista pode adotar, conforme a tabela:

Tabela 4.01 Níveis de eficiência de proteção [04]

\begin{tabular}{|c|l|c|}
\hline \multicolumn{3}{|c|}{ PROTECÁO E EFICIENCIA CONTRA DESCA RGAS ATMOSFERICAS } \\
\hline Nível de Proteção & \multicolumn{1}{|c|}{ Características da Proteção } & Eficiência da Proteção \\
\hline I & Nível máximo de proteçăo & $98 \%$ \\
\hline II & Nível médio de proteção & $95 \%$ \\
\hline III & Nível moderado de proteção & $90 \%$ \\
\hline IV & Nível normal de proteção & $80 \%$ \\
\hline
\end{tabular}

A classificação das edifições e níveis de proteção segundo a NBR 5419/2005 de acordo com os efeitos e danos causados pelos raios, as estruturas podem ser classificadas em:

- Estruturas comuns;

- Estruturas com danos confinados;

- Estruturas com perigo aos arredores;

- Estruturas com danos ao meio ambiente.

Para maiores detalhes, vide Anexo A - Tabela de classificação das estruturas quanto ao nível de proteção, segundo a NBR 5419/2005.

\section{2 - Definição de SPDA}

De acordo com a NBR 5419/2004, SPDA - Sistema de proteção contra descargas atmosféricas é um sistema completo destinado a proteger uma estrutura contra os efeitos 
das descargas atmosféricas. É composto de um sistema externo e de um sistema interno de proteção.

- Sistema externo: sistema que consiste em subsistema de captores, subsistema de condutores de descida e subsistema de aterramento.

- Sistema interno: conjunto de dispositivos que reduzem os efeitos elétricos e magnéticos da corrente de descarga atmosférica dentro do volume a proteger (DPS - dispositivo de proteção contra surtos).

O objetivo do SPDA é blindar uma estrutura, seus ocupantes e seus conteúdos dos efeitos térmicos, mecânicos e elétricos associados com os raios. O sistema atua de modo que a descarga atmosférica possa entrar ou sair do solo sem passar através das partes condutoras da estrutura ou através de seus ocupantes evitando danos ou acidentes. Lembrando que um sistema de proteção contra raios não impede que o raio atinja a estrutura; ele promove um meio para controlar e impedir danos através da criação de um caminho de baixa resistência elétrica para a corrente elétrica fluir para o solo.

No entanto, conforme transcrição do início da Norma NBR 5419, o objetivo de um SPDA é proteger contra descargas diretas:

1.1 Esta Norma fixa as condições exigíveis ao projeto, instalação e manutenção de sistemas de proteção contra descargas atmosféricas (SPDA) das estruturas definidas em 1.2, bem como das pessoas e instalações no seu aspecto físico dentro do volume protegido.

1.2 Esta Norma aplica-se a estruturas comuns, utilizadas para fins comerciais, industriais, agrícolas, administrativos ou residenciais, e às estruturas especiais previstas no Anexo A.

1.3 Esta Norma não se aplica a:

1.3.1 Sistemas ferroviários;

1.3.2 Sistemas de geração, transmissão e distribuição de energia elétrica externos às estruturas;

1.3.3 Sistemas de telecomunicação externos às estruturas;

1.3.4 Veículos, aeronaves, navios e plataformas marítimas.

1.4 Esta Norma não contempla a proteção de equipamentos elétricos e eletrônicos contra interferências eletromagnéticas causadas pelas descargas atmosféricas.

1.5 A aplicação desta Norma não dispensa a observância dos regulamentos de órgãos públicos aos quais a instalação deva satisfazer. 
Todo SPDA, ou seja, Sistema de proteção contra descargas atmosféricas é subdividido em 3 subsistemas:

1. Subsistema de captores

2. Subsistema de descida (cabos)

3. Subsistema de aterramento

Cada um desses subsistemas têm importância fundamental para $\mathrm{o}$ bom funcionamento de um SPDA. No entanto, como relatado na NBR 5419/2005, nenhum SPDA garante $100 \%$ de confiabilidade e garantia de sucesso; sendo, portanto, um sistema para minimização de riscos, estragos materiais ou acidentes físicos.

Para se ter uma idéia de como essa afirmativa é verdadeira (falibilidade de SPDA), abaixo descrevemos um exemplo de estrutura com área classificada como Zona I junto ao telhado e protegida por cabos suspensos (captores) afastados da estrutura, com descidas também afastadas das faces laterais, num tipo de proteção denominado isolada [04].

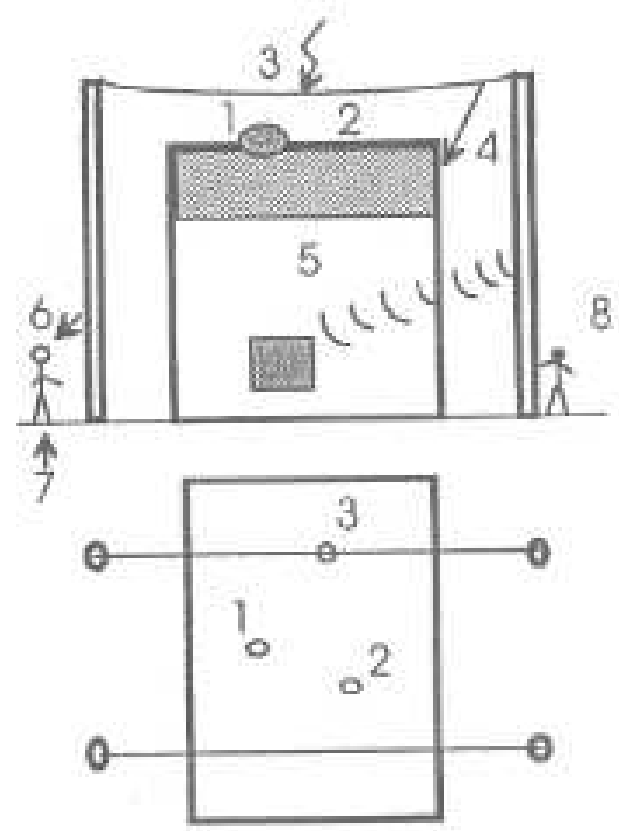

Figura 4.01 Falibilidade dos sistemas de proteção [04]

Tendo dito isto, são estes os acidentes que podem ocorrer:

1. Falha da blindagem direta - uma descarga consegue passar entre os cabos captores ou ao lado deles e chegar à área classificada externa, causando um 
incêndio ou explosão. Para que isto não ocorresse, o número de cabos deveria ser aumentado, diminuindo-se a distancia entre eles.

2. Falha da auto proteção - uma descarga passa pelos cabos captores e atinge o teto fora do volume da área classificada externa, provoca fusão da telha metálica e isto inflama a mistura da zona I logo abaixo do teto. Isto seria evitado se a espessura da telha fosse tal que não houvesse perfuração nem aquecimento da face em contato com a mistura.

3. Falha no dimensionamento - o raio atinge o cabo captor, o qual se funde, caindo material aquecido sobre a zona I e causando incêndio ou explosão. Isto ocorre quando o cabo não suporta o aquecimento no ponto de impacto do raio e sua seção deve ser aumentada.

4. Falha na proximidade - o raio atinge o cabo captor e se dirige à terra pelas descidas, mas as tensões $\mathbf{L . d i} / \boldsymbol{d t}$ geradas ao longo do percurso são suficientes para produzir descargas ao teto ou às paredes, podendo causar incêndios e explosões soluções: agastar mais os captores do teto e as descidas das paredes laterais, colocar captores cruzados (formando uma malha) ou ainda aumentar o número de captores e descidas de modo a reduzir a indutância do caminho da corrente.

5. Falha da blindagem indireta - a corrente resultante da queda do raio, ao passar pelos condutores de descida, dá origem a campos eletromagnéticos que podem causar sobre-tensões induzidas na fiação das instalações elétricas, ou danos diretos a equipamentos eletrônicos com componentes muito sensíveis, os quais também poderão ser danificados pelas referidas tensões induzidas. Soluções: aumentar o numero de descidas, promover equalização dos potenciais, blindar os equipamentos mais sensíveis e os condutores, melhorar a topologia das instalações elétricas e proteger as linhas e os equipamentos com dispositivos de proteção contra Sobretensões (DPS).

6. Geração de descarga lateral - as correntes nos condutores de descida causam quedas de tensão ao longo desses componentes e podem dar origem a descargas laterais às pessoas que estejam em suas proximidades; estas tensões são a soma da queda de tensão indutiva $\mathbf{L}$.di/dt ao longo dos contadores de descida com as quedas de tensão R.i no sistema de terra. Solução: aumentar o numero de condutores e, ao mesmo tempo, melhorar o aterramento, reduzindo $\boldsymbol{R}$. 
7. Geração de tensões de passo - as correntes, ao se dispersarem no solo, produzirão tensões de passo perigosas às pessoas que estiverem nas vizinhanças do sistema de proteção. Solução: melhorar o sistema de aterramento, diminuindo as tensões geradas no solo ou cobrir o terreno com uma camada de concreto, asfalto ou pedra britada, o que diminui a corrente que pode passar pelo corpo da vítima.

8. Geração de tensões de toque - uma pessoa pode tocar inadvertidamente um condutor de descida no qual está naquele momento sendo gerada uma tensão L.di/dt + R.i. Solução: análoga aos casos 6 e 7, ou providenciar meios de afastar as pessoas dos condutores de descida, pela colocação de avisos ou obstáculos.

Por este exemplo, podemos concluir que há uma dificuldade muito grande em se avaliar os riscos, embora a probabilidade de ocorrer um raio sobre uma estrutura possa ser baixa (1 descarga a cada 2, 5,10, ou 20 anos), as conseqüências de uma hipotética situação de descarga sobre ou próxima da construção poderá ser muito ruim, tanto do ponto de vista material como pessoal. [04]

\section{3 - Componentes de um SPDA}

Qualquer que seja o método de proteção utilizado, ele será composto por três partes (ou subsistemas):

- Subsistema de captores: tem a função de receber os raios, reduzindo ao mínimo a probabilidade da estrutura ser atingida, e ter a capacidade térmica e mecânica de suportar o calor gerado no ponto de impacto, bem como os esforços eletromecânicos resultantes;

- Subsistema de descida: tem a função de conduzir a corrente do raio recebida pelos captores até o aterramento, reduzindo ao mínimo a probabilidade de descargas laterais e de campos eletromagnéticos perigosos no interior da estrutura;

- Subsistema de aterramento: tem a função de dispersar no solo a corrente recebida dos condutores de descida, reduzindo ao mínimo a probabilidade de tensões de toque e de passo perigosas. 
Além destes conceitos há ainda mais alguns muito importantes:

- Componentes naturais: são aqueles existentes na estrutura e que não só podem como devem ser usados no sistema de proteção (antenas de TV instaladas no alto de residências são consideradas pela norma NBR 5419/2005 como captores naturais);

- Componentes especiais: são aqueles colocados na estrutura com a finalidade explicita de receber, conduzir ou dispersar no solo as correntes dos raios.

- Proteção isolada: é aquela em que os componentes do sistema de proteção estão colocados acima e ao lado da estrutura, mantendo uma distância em relação a esta suficientemente alta para evitar o impacto direto sobre a estrutura.

- Proteção não-isolada: é aquela em que captores e descidas são colocados diretamente sobre a estrutura.

Estes três elementos devem funcionar como um sistema só para garantir sua funcionalidade básica: proteção para estruturas, seres humanos, equipamentos, etc.

\subsection{1 - Subsistema de Captores}

Os diferentes métodos (filosofias) de proteção, na verdade, são diferentes maneiras de se captar os raios, visto que as descidas e o aterramento permanecem os mesmos. Dessa forma, temos dois princípios de captação: o $1^{\circ}$ utilizado pelos métodos de Franklin e Eletrogeométrico emprega hastes metálicas verticais (os pára-raios propriamente ditos), ou cabos horizontais suspensos (seguindo a mesma idéia dos cabos de guarda utilizados em linhas de transmissão); o $2^{\circ}$ princípio, utilizando o método da gaiola de Faraday, composto por condutores horizontais, não suspensos, formando uma malha apoiada sobre a estrutura.

Falando ainda do $1^{\circ}$ princípio, os métodos de Franklin e Eletrogeométrico diferem quanto ao modelo matemático utilizado: o método de Franklin é baseado apenas em observações, enquanto que o Eletrogeométrico utiliza um modelamento estudado e comprovado em linhas de transmissão e subestações. Alguns países, como os EUA, em sua norma NFPA 780/2004 já não citam mais o tipo Franklin como alternativa, resumindo-se ao Eletrogeométrico e o Faraday. 


\subsubsection{1 - Filosofia "Franklin"}

A filosofia deste sistema fundamenta-se na interceptação de eventuais canais descendentes que se aproximem da estrutura por meio de canais ascendentes que se iniciem a partir dos captores das pontas dos captores, baseado na proposta inicial feita por Benjamim Franklin.

Estes captores são corpos metálicos e alongados (hastes, mastros, etc) posicionados nas partes mais elevadas da estrutura, de forma a se destacar por sobre elas. Estas hastes, em forma de ponta, produziriam sob a nuvem carregada uma alta concentração de cargas elétricas, juntamente com um campo elétrico intenso. Isto contribuiria para a ionização do ar, diminuindo a altura efetiva da nuvem carregada, propiciando ao raio um canal facilitado para o rompimento da rigidez dielétrica da camada de ar.

A proposta inicial de Franklin de um terminal pontiagudo para aproveitar o efeito das pontas não estava correta (Pode-se demonstrar em laboratório de alta tensão que um terminal arredondado apresenta um desempenho melhor que um pontiagudo, mas a diferença é pequena e a influência da forma do terminal é desprezível em termos práticos). A explicação física é que sendo pontiagudo o terminal, quando há um aumento do campo elétrico surgem partículas ionizadas, formando-se uma esfera condutora (ou efeito corona) que uniformiza o campo e dificulta a saída do líder ascendente. Se a ponta for arredondada (ou rombuda) não haverá esse efeito e o líder ascendente sairá instantaneamente a um valor mais baixo do campo elétrico. O valor do assim chamado raio crítico para o terminal é de difícil determinação, pois ele depende da forma da onda da tensão com que é realizado o ensaio, melhor dizendo, depende dos tempos de subida até a crista e da duração do impulso de tensão. Dessa forma, podemos afirmar que a eficiência do método não depende da forma do captor, sendo indiferente usar captor de 1, 2, 3 ou mais pontas, de forma que o importante para esse método é que haja um captor em forma de buquê. Posteriormente, o mesmo princípio do ângulo de proteção foi estendido a captores sob a forma de condutores horizontais suspensos por postes ou torres e usados principalmente na proteção de linhas de transmissão de alta tensão e na proteção isolada de edificações.

A figura abaixo mostra os componentes básicos do sistema. A outra figura mostra uma variação da configuração de captores, que denota a possibilidade de se alcançar a mesma blindagem promovida pela haste elevada, através de uma configuração com três hastes curtas (ao estilo "dividir para conquistar"). 
Os captores também podem ser cabos estendidos na parte superior da estrutura ou por hastes obliquas, posicionadas nas extremidades da edificação.

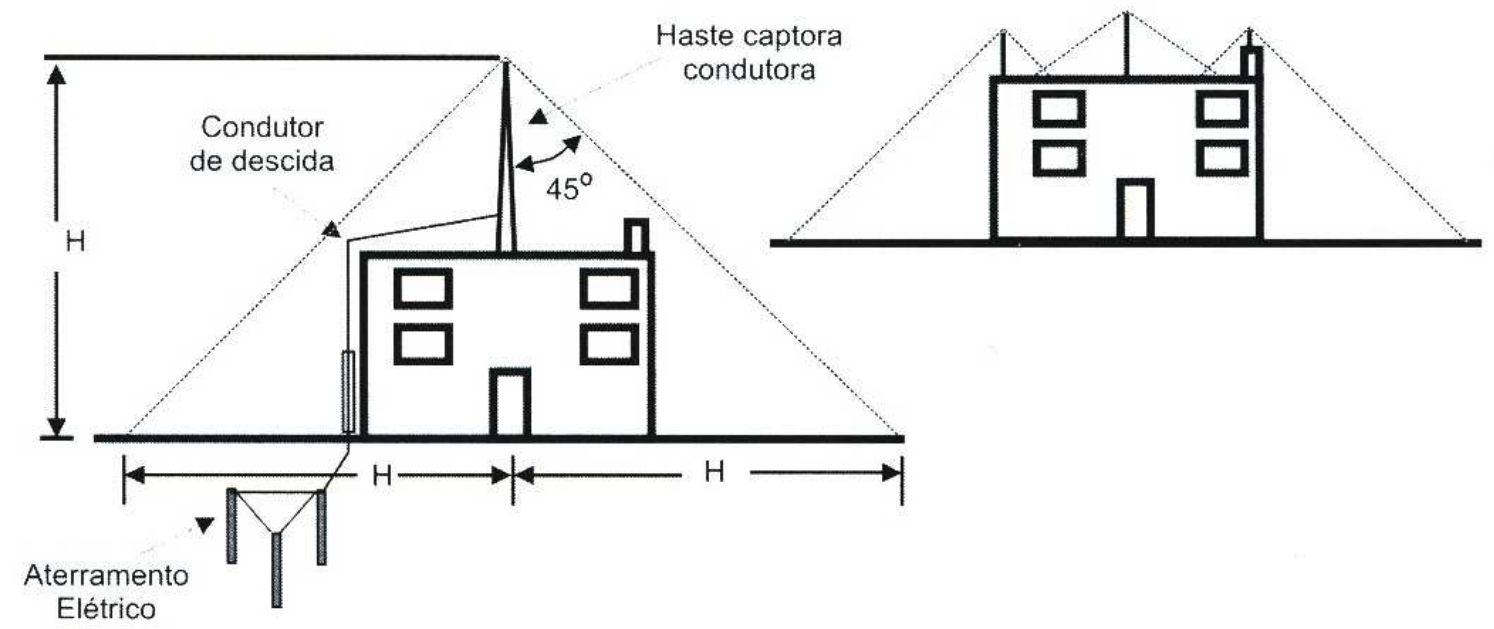

Figura 4.02 Configuração de um SPDA tipo Franklin [06]

O raio captado pela ponta da haste é transportado pelo cabo de descida e escoado na terra pelo sistema de aterramento. Se a bitola do cabo de descida, conexões e aterramento não forem adequados, as tensões ao longo do sistema que constitui o pára-raios serão elevadas e a segurança, comprometida.

O volume de proteção de uma haste vertical é o de um cone, com ângulo no vértice igual ao ângulo de proteção, obtido pela rotação de um triângulo retângulo e, no caso dos condutores horizontais suportados por hastes verticais, o volume de proteção será obtido pelo deslocamento horizontal do cone de proteção desde a posição de uma haste até a posição da outra haste.

Estes ângulos são indicados em normas de proteção e dependem do nível de proteção desejado, sendo tanto menor quanto mais estrita for o nível de segurança. Podemos concluir que este sistema, por sua simplicidade de aplicação, é o mais comum dos sistemas de captores; no entanto, ele é mais indicado para construções de pequeno porte. A tabela abaixo ilustra os ângulos indicados na norma brasileira, destacando que o método de Franklin é totalmente aceito apenas para estruturas não superiores a $20 \mathrm{~m}$ de altura. Sendo que nos demais casos, a preferência é pelos demais métodos. 
Tabela 4.02 Ângulo de proteção em função da altura [24]

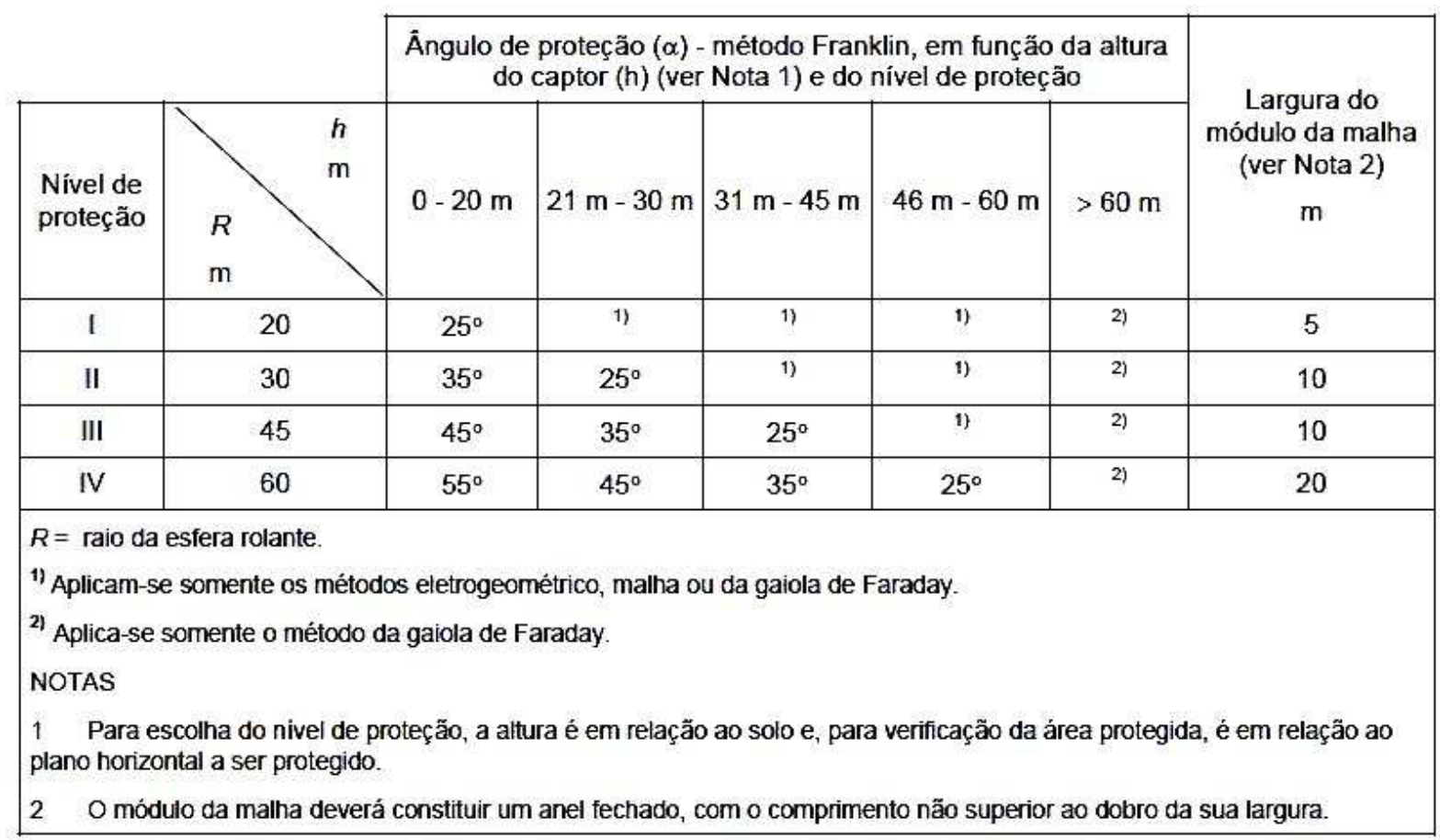

O método de Franklin foi objeto de estudo quanto à determinação do volume de proteção de uma haste vertical e o valor do ângulo de proteção. Este volume de proteção raramente é obtido na prática, pois o condutor Horizontal é um cabo tensionado pelos suportes verticais e descrevendo uma curva (catenária) que depende do seu próprio peso e da tensão com a qual for esticado.

A Comissão de Estudos (órgão responsável pela atualização da norma brasileira) estuda possibilidade de retirada do método Franklin do documento. Essa tecnologia era a única permitida na primeira versão do documento, elaborado em 1977. Na primeira revisão da norma, o método já passou por modificações e sofreu uma série de restrições.

De acordo com o membro da comissão que avalia a revisão da norma, o diretor da Encontre Engenharia, o engenheiro mecânico eletricista Duílio Moreira Leite, as opiniões são divergentes quanto à retirada desse sistema da norma.

Os motivos apresentados pelos membros a favor de sua retirada são que o método é mais caro, em razão da quantidade de capturas necessárias, e interfere, ainda, negativamente na arquitetura dos prédios nos quais é instalado. Apesar disso, Leite defende que o modo é mais fácil de fazer e de direcionar, o que o torna mais viável para as pequenas instalações. 
Segundo ele, a retirada do documento já foi estudada também na IEC 62305, mas não foi aprovada. "Na época eu fazia parte da IEC e votei em não ser retirado e acho que deve ser mantido aqui também”, opina. Alguns países já retiraram esse método e a alternativa foi o uso do método eletrogeométrico, que é mais econômico, mas com instalação mais trabalhosa [32].

\subsubsection{2 - Filosofia "Gaiola de Faraday"}

Este é o método mais utilizado na Europa. Baseado na teoria de Faraday segundo a qual o campo no interior de uma esfera metálica será nulo, desde que a corrente seja distribuída uniformemente por toda a superfície da esfera. Baseado nesse princípio, faz-se uma aproximação da esfera (situação ideal) para uma gaiola metálica. Como campo será nulo apenas no interior da gaiola, sempre haverá um campo nas proximidades dos condutores que poderá dar tensões induzidas em condutores das instalações elétricas em paralelo à malha metálica (a gaiola). Como dito anteriormente, a proteção máxima seria obtida quando a estrutura fosse envolvida por uma esfera metálica de paredes soldadas e de espessura suficiente para suportar os efeitos térmicos e de impacto do raio (por isso que um dos locais mais seguros contra descargas indiretas durante uma tempestade seja no interior de veículos cuja carcaça seja metálica). Quando as correntes não são uniformes, o campo no seu interior não é nulo, mas muito pequeno. O raio ao cair na estrutura, tende a não se distribuir uniformemente pela malha, e por esse motivo podem ocorrer induções internas devido à variação do campo magnético existente no interior da Gaiola.

A implementação desta filosofia requer a construção de uma gaiola condutora envolvendo toda a estrutura. Costuma-se colocar um condutor em volta do perímetro da estrutura, fixado sobre as laterais da superfície superior, denominado condutor de equalização de potencial. Partindo deste anel superior, derivam-se cabos de descida de tal forma que cubram todos os vértices da estrutura. Além disso, a cada $20 \mathrm{~m}$ de descida há um novo anel interligando todos os cabos de descida até o aterramento, também formatado em anel. A figura 4.03 ilustra a configuração típica deste tipo de esquema. 


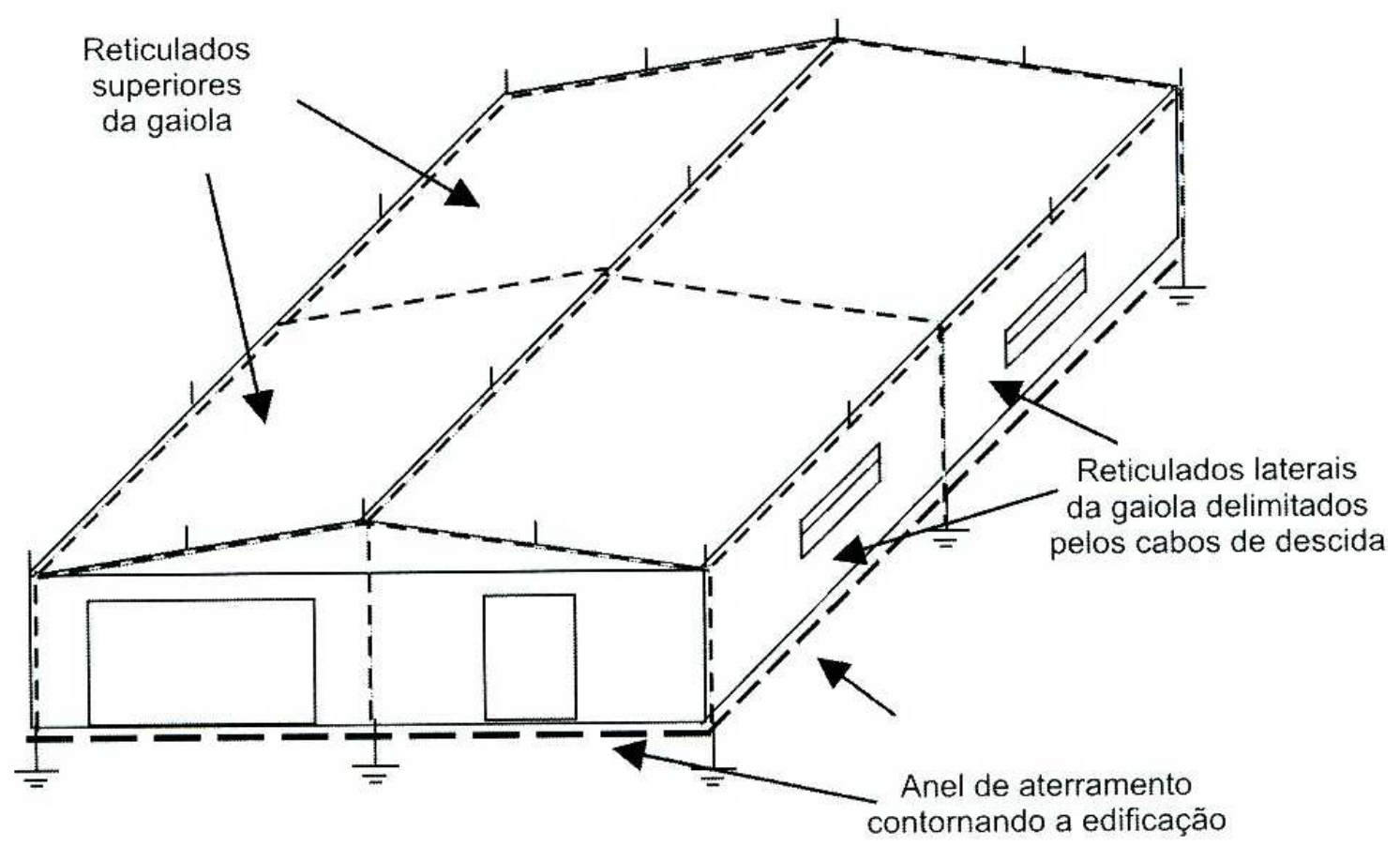

Figura 4.03 Configuração de um SPDA tipo Gaiola de Faraday [06]

A distância entre os condutores da malha está relacionada com o nível de proteção desejado, visto que quanto menor a distância entre os condutores, melhor será a proteção obtida. A tabela abaixo indica dimensões limites sugeridas na norma brasileira. Esta restrição tem o objetivo de assegurar que não haja vazamento da blindagem quanto à incidência de raios.

Tabela 4.03 Largura máxima entre cabos do reticulado [06]

\begin{tabular}{|c|c|}
\hline Nível de Proteção & Distância Máxima dos Espaçamentos \\
\hline I & $5,0 \mathrm{~m}$ \\
\hline II & $10,0 \mathrm{~m}$ \\
\hline III & $10,0 \mathrm{~m}$ \\
\hline IV & $20 \mathrm{~m}$ \\
\hline
\end{tabular}

O módulo da malha deve constituir um anel fechado de comprimento não superior ao dobro de sua largura.

Para edificações maiores que $60 \mathrm{~m}$ de altura, a norma brasileira só permite a utilização do método de Faraday, conforme pode ser visto na tabela 4.03. Para diminuir a possibilidade dos condutores da malha captora serem danificados nos pontos de impacto, a norma brasileira recomenda a colocação de pequenos captores verticais, denominados 
terminais aéreos, com 30 a $50 \mathrm{~cm}$ de altura, separados por uma distância de 5 a $8 \mathrm{~m}$ ao longo dos condutores da malha. Lembrando que todas as partes metálicas existentes no teto de uma construção, como escadas, beirais, antenas, etc. farão parte do sistema captor (captores naturais) e, portanto, devem ser interligados aos condutores mais próximos.

\subsubsection{3 - O modelo eletrogeométrico (EGM)}

O modelo eletrogeométrico, também conhecido como o método da esfera rolante, esfera fictícia ou método da bola é uma evolução do método de proteção tipo Franklin, onde a tangente ao invés de ser reta é parabólica (raio de atração). Este método surgiu na década de 70 e foi desenvolvido pela engenharia de linhas de transmissão da Europa com o objetivo de minimizar os danos materiais com desligamentos dessas linhas. Em síntese este modelo consiste, em fazer rolar uma esfera fictícia de raio $\left(\mathrm{R}_{\mathrm{a}}\right)$ sobre a edificação, em todos os sentidos, determinando assim os locais de maior probabilidade de serem atingidos por uma descarga atmosférica, tendo como base que esses locais têm grande potencialidade de geração de lideres ascendente, que deverão se precipitar ao encontro com o líder descendente.

O de raio de atração $\left(R_{a}\right)$ é a distância estimada entre um canal ionizante e uma estrutura terrestre, a partir do qual ocorrerá fechamento do percurso formado pelo piloto descendente (originado na nuvem) e o piloto ascendente (originado no objeto conectado à terra). Caso tal distância seja alcançada, a probabilidade de que o raio use esta estrutura como caminho de descarga é muito grande.

Através de experimentos laboratoriais com modelos de escala reduzida, de registros fotográficos e de filmagens da incidência de descargas reais em torres instrumentadas, foram desenvolvidas relações empíricas que relacionam o raio de atração com o valor de pico da corrente de descarga $\left(I_{p}\right)$. A NBR 5419 indica a seguinte relação:

$$
R_{a}=2 . I_{p}+30 \cdot\left(1-e^{-I_{p}}\right)
$$

A tabela 4.01 indica valores estimados do raio de atração para diferentes valores de pico da corrente de descarga, através da aplicação da expressão acima. 
Tabela 4.04 Raio de atração em função da corrente de descarga [06]

\begin{tabular}{|c|c|}
\hline $\begin{array}{c}\text { Valor de pico da } \\
\text { corrente (kA) }\end{array}$ & $\begin{array}{c}\mathbf{R}_{\mathbf{a}}=2 .\left(\mathrm{I}_{\mathrm{P}}\right)+\mathbf{3 0} \cdot\left(\mathbf{1}-\mathrm{e}^{-\mathrm{I}_{\mathrm{P}}}\right) \\
(\mathbf{m})\end{array}$ \\
\hline 5 & 40 \\
\hline 10 & 50 \\
\hline 15 & 60 \\
\hline 20 & 70 \\
\hline 30 & 90 \\
\hline 50 & 130 \\
\hline 100 & 230 \\
\hline
\end{tabular}

Com a adoção do conceito do raio de atração é possível definir com precisão a região de incidência. Conforme pode ser visto na figura abaixo. Nesta figura, considera-se a linha constituída por três condutores energizados (fases) e um condutor de blindagem (cabo pára-raios: G). A figura apresenta a análise da proteção da linha especificamente para a incidência de uma corrente de descarga de valo de pico $10 \mathrm{kA}$, ao qual está associado um raio de atração de $50 \mathrm{~m}$, conforme tabela 4.01. Na figura estão traçadas circunferências de raio igual ao raio de atração $\left(R_{a}\right)$, centradas sobre o eixo de cada um dos condutores da linha. Está também traçada uma linha horizontal, cuja distância ao solo é igual ao raio de atração. Tais circunferências e linha correspondem ao corte respectivamente de superfícies cilíndricas (em cujo eixo localizam-se os condutores) e do plano paralelo à superfície do solo, definidos ao longo da linha de transmissão [06].

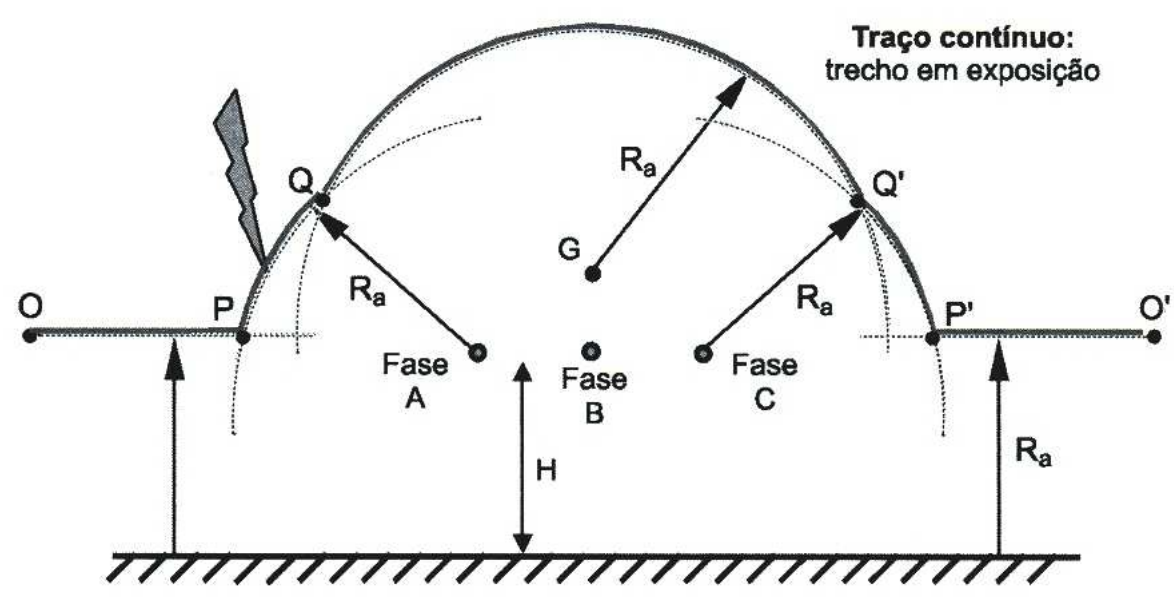

Figura 4.04 Representação esquemática de aplicação do EGM [06] 
A curva OPQQ'P'O' foi traçada sobre os pontos mais externos das circunferências e da linha horizontal. Estes pontões são os prováveis primeiros pontos de contato com descargas descendentes que se aproximem da LT.

Isto significa que se um raio atingir o arco $\mathrm{PQ}$, ele estará dentro do raio de atração da Fase A, que será atingida pelo raio. Após sucessivos testes, concluiu-se que quanto menor a amplitude da onde de corrente do raio, maior a probabilidade deste atingir seu alvo. Como prova disto, temos as figuras 4.xx abaixo. Sendo que a do lado esquerdo trata do caso de uma corrente de $5 \mathrm{kA}$ e a outra figura, para uma corrente de $20 \mathrm{kA}$.
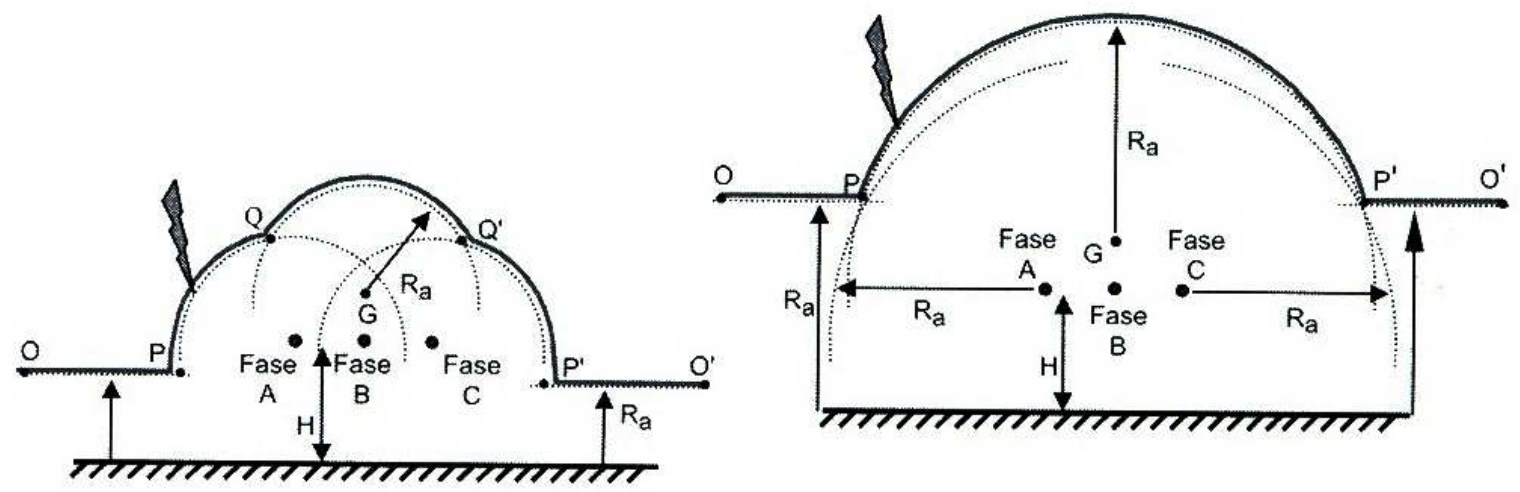

Figura 4.05 Efeito da amplitude de corrente na blindagem de linha [06]

$\mathrm{Na}$ busca do aprimoramento da tecnologia, foram desenvolvidas expressões que tentam computar outros efeitos que exercem influência na definição do raio de atração, incluindo as características da estrutura a ser protegida, como sua altura $(\mathrm{H})$. A tabela 4.06 mostra o efeito da altura da estrutura no raio de atração, considerando-se diferentes níveis de corrente, pela aplicação da expressão abaixo [06]:

$$
R_{a}=I_{p}^{0,64} \cdot H^{\left(0,66+2 \cdot I_{p} \cdot 10^{-4}\right)}
$$


Tabela 4.06 Efeito da altura da estrutura no valor do $R_{a}[06]$

\begin{tabular}{|c|c|c|c|}
\hline $\begin{array}{l}\text { Valor de pico da } \\
\text { corrente (kA) }\end{array}$ & $\begin{array}{c}\operatorname{Ra}(\mathbf{m}) \\
10\left(\mathbf{I}_{\mathbf{P}}\right)^{0,66}\end{array}$ & $\begin{array}{l}\text { Altura } \\
\mathbf{H}(\mathbf{m})\end{array}$ & $\begin{array}{c}\mathbf{R}_{\mathbf{a}}(\mathbf{m}) \\
\mathrm{R}_{\mathbf{a}}=\mathrm{H}^{\left(0,66+2 \cdot \mathrm{I}_{\mathrm{p}} \cdot 10^{-4}\right)} \cdot \mathrm{I}_{\mathrm{P}}^{0,64}\end{array}$ \\
\hline \multirow{4}{*}{5} & \multirow{4}{*}{29} & 10 & 13 \\
\hline & & 20 & 20 \\
\hline & & 40 & 32 \\
\hline & & 80 & 51 \\
\hline \multirow{4}{*}{10} & \multirow{4}{*}{46} & 10 & 20 \\
\hline & & 20 & 32 \\
\hline & & 40 & 50 \\
\hline & & 80 & 79 \\
\hline \multirow{4}{*}{20} & \multirow{4}{*}{72} & 10 & 31 \\
\hline & & 20 & 50 \\
\hline & & 40 & 79 \\
\hline & & 80 & 125 \\
\hline \multirow{4}{*}{50} & \multirow{4}{*}{132} & 10 & 57 \\
\hline & & 20 & 91 \\
\hline & & 40 & 145 \\
\hline & & 80 & 230 \\
\hline
\end{tabular}

\subsubsection{4 - Sistema Híbrido}

Em muitas situações tem sido adotada uma configuração híbrida (ou mista), tentando aproveitar o melhor de cada sistema de proteção. Basicamente, adota-se a proteção por Gaiola de Faraday, complementada por um sistema de captação tipo Franklin, para proteção específica dos corpos elevados da cobertura da estrutura. Nesta configuração, sempre é colocado um anel condutor envolvendo a periferia da parte superior da estrutura (laje ou telhado). Os dois sistemas são integrados de tal forma que os próprios condutores que conectam as hastes Franklin ao cabo periférico da cobertura são dispostos de modo a constituir reticulados superiores.

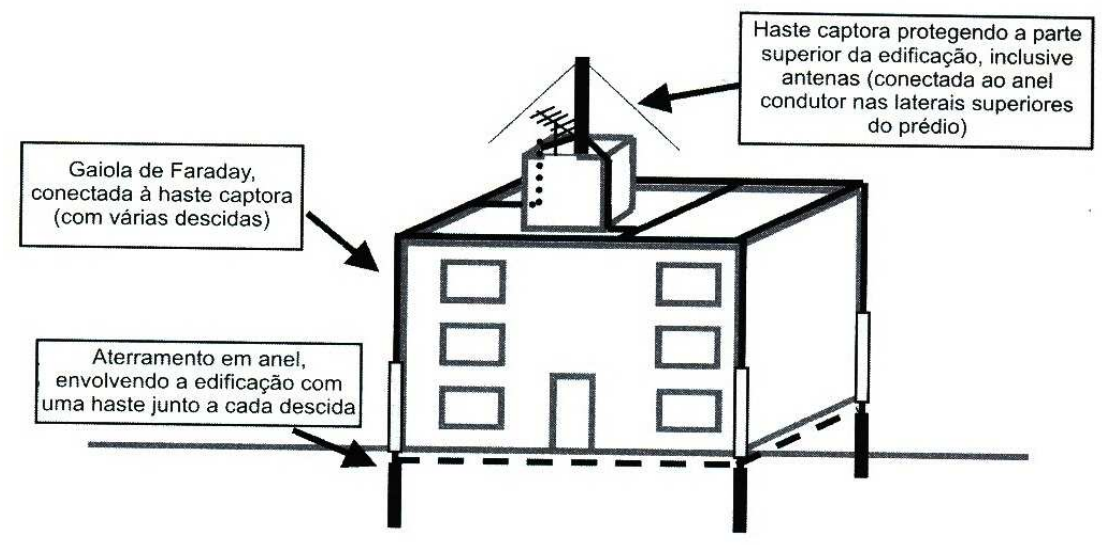

Figura 4.06 Configuração hibrida [06] 
Eventuais descargas incidentes na cobertura são captadas pelas hastes superiores ou pelos condutores superiores da cobertura. A corrente de descarga é dirigida para o cabo periférico colocado nas muretas laterais da cobertura (cabo de equalização), que a distribui pelos cabos de descida posicionados nos vértices da construção. Por fim, as descidas levam a corrente até o aterramento (em anel), sendo colocado uma haste de aterramento no fim de cada cabo de descida e esta haste, ligada ao anel.

\subsection{2 - Cabos de descida}

Depois da descarga atingir o sub-sistema de captor da estrutura, a corrente deverá ser conduzida ao subsistema de aterramento pelos cabos de descida. O número de condutores utilizados, o distanciamento entre eles e sua seção transversal deverão ser escolhidos de tal forma que:

- Suportem térmica e mecanicamente as correntes e respectivos esforços;

- Os campos eletromagnéticos internos sejam mínimos;

- Não haja descargas laterais;

- Não haja riscos para as pessoas próximas;

- Não haja danos às paredes;

- Suportem o impacto dos raios (nas estruturas altas);

- Resistam às intempéries e à corrosão.

Para que todas estas condições sejam satisfeitas é imprescindível que haja um planejamento antes do prédio ser construído, visto que, por tirarem "a beleza" da fachada costumam ser ponto de conflito entre profissionais de engenharia e arquitetura. Se possível, ainda no momento do projeto da construção, prever o uso da malha de ferro como proteção. 


\section{4 - Modelo de descargas de retorno}

Uma grande preocupação dos projetistas de sistemas de proteção para LT é saber a forma do impulso da corrente de descarga do raio, que escoa entre a nuvem e terra ou entre nuvens.

Na literatura relativa à proteção contra descargas atmosféricas é muito comum a referência a uma onda dupla exponencial, usualmente designada como onda de impulso atmosférico [06]. Apesar desta representação da frente de onda não ser muito fiel comparada à uma real, ela se tornou uma forma de padronização para resultados laboratoriais quando da avaliação das conseqüências de surtos de tensão e corrente associados a descargas atmosféricas diante de equipamentos e dispositivos eletrônicos. A figura abaixo ilustra uma onda de corrente deste tipo e o circuito para sua geração.

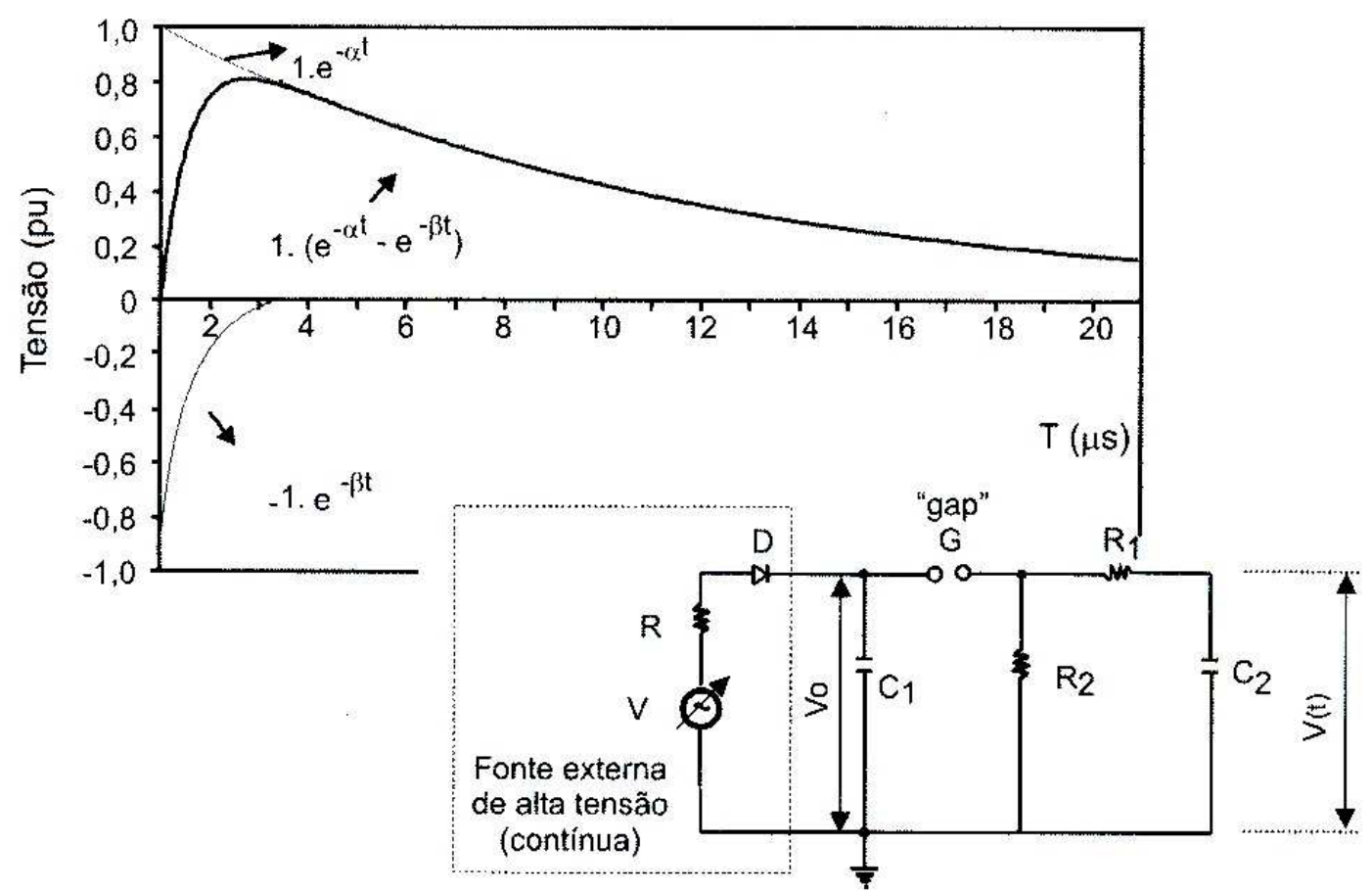

Figura 4.07 Curva exponencial dupla [06]

A onda constitui-se na soma de duas ondas exponenciais de sinais contrários e constantes de tempo de valor muito diferente. No instante inicial, ambas as ondas têm a mesma amplitude, resultando em um valor nulo para a soma. Enquanto a onda positiva se atenua lentamente no tempo, muito rapidamente, a onda negativa se anula, e a soma resultante tem um aspecto impulsivo, indicado pela linha mais espessa da figura. 
A adoção deste tipo de curva decorre, sobretudo, da facilidade de sua geração em ambiente laboratorial. Esta pode ser obtida em experimentos por meio da simples descarga de um capacitor sobre um circuito "RC", similar ao indicado na figura 6.01, onde deve estar posicionada a amostra sob ensaio.

Tentando suprir a falta de representatividade dessa onda dupla exponencial, o pesquisador alemão Heidler propôs uma função analítica capaz de representar adequadamente as curvas médias ou medianas obtidas a partir dos dados de medição direta de ondas de corrente em torres "instrumentadas". Atualmente, tal curva tem sido muito adotada, sobretudo nas simulações para avaliação dos efeitos gerados pelo fluxo da corrente de retorno.

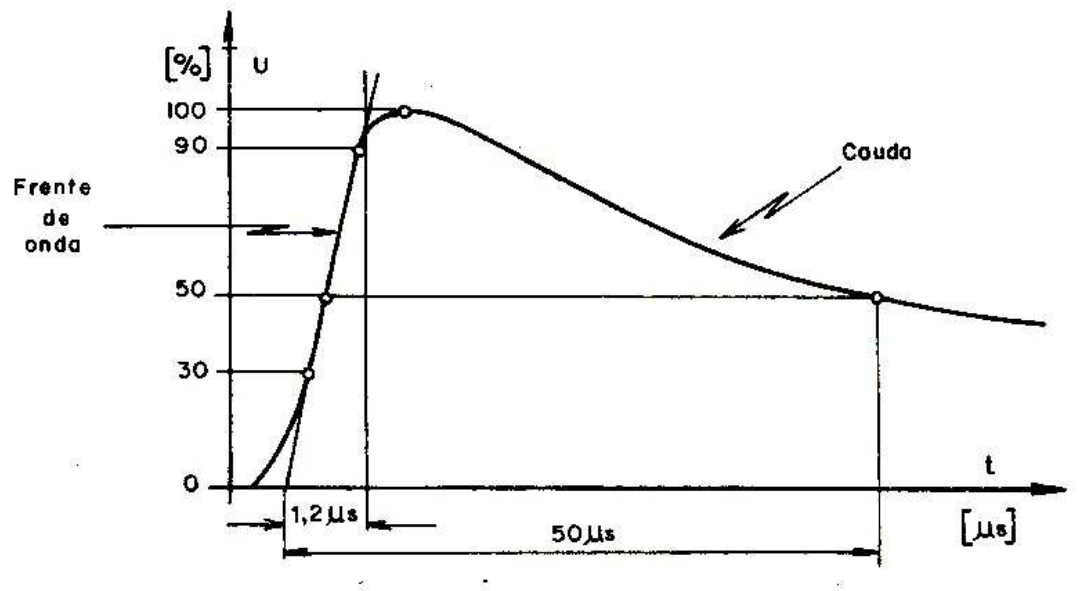

Figura 4.08: Curva de Heidler [02]

Pela figura acima, pode-se definir alguns termos importantes da descarga do raio:

- Frente de onda: Tempo de subida da corrente ou tensão do raio até atingir seu valor de pivo. A frente da onda corresponde à ação fulminante do raio;

- Valor de crista: Valor de pico alcançado pela corrente ou tensão do raio;

- Cauda do raio - Tempo decorrido desde o valor de crista até o final do raio;

- Período ou Tempo de Meia Cauda - Tempo em que a cauda atinge o valor de meia crista. 
Em termos de efeito e danos, basta considerar o raio até o seu período de meia cauda, isto porque, se o equipamento a ser protegido sobreviver ao raio até a meia cauda, o restante do período da cauda final será mais suave e de menor intensidade.

A curva de Heidler contempla a natureza côncava da onda nos seus instantes iniciais. Também, observa parcialmente o posicionamento adequado da derivada máxima próximo ao pico e tem, ainda, o decaimento de sua amplitude após a ocorrência do pico muito similar àquele das curvas medianas. A curva é obtida através da aplicação de uma expressão analítica, chamada de função de Heidler. Esta permite o ajuste, de forma independente, da amplitude da corrente, da derivada máxima de corrente e da carga transferida, através da variação das constantes $I_{0}, \tau_{1}$ e $\tau_{2}$. A expressão dessa função é apresentada abaixo:

$$
i(t)=\frac{I_{0}}{\eta} \cdot \frac{\left(t / \tau_{1}\right)^{n}}{1+\left(t / \tau_{1}\right)^{n}} \exp \left(-t / \tau_{2}\right)
$$

\footnotetext{
$\mathrm{Na}$ qual

$\mathrm{I}_{0}$ : Amplitude da corrente na base do canal do raio;

$\tau_{1}$ : Constante de tempo frontal;

$\tau_{2}$ : Constante de tempo de decaimento;

$\eta$ : Fator de correção da amplitude da corrente, e

n: Expoente (de 2 a 10).
}

O fator de correção da amplitude da corrente é obtido através da seguinte expressão:

$$
\eta=\exp \left[-\left(\tau_{1} / \tau_{2}\right)\left(n \tau_{1} / \tau_{2}\right)^{(1 / n)}\right]
$$

Como exemplo, a figura abaixo representa duas correntes na base do canal do raio. As ondas de $\tau_{1} / \tau_{2}$ de $1,2 / 50 \mu$ s para a tensão, e $5 / 20 \mu$ s para a corrente, são as 
tradicionalmente usadas nos ensaios [06], assumindo-se ainda $\mathrm{I}_{0}=50 \mathrm{kA}$ e $\mathrm{n}=2$ como valores típicos dos parâmetros da forma de onda:

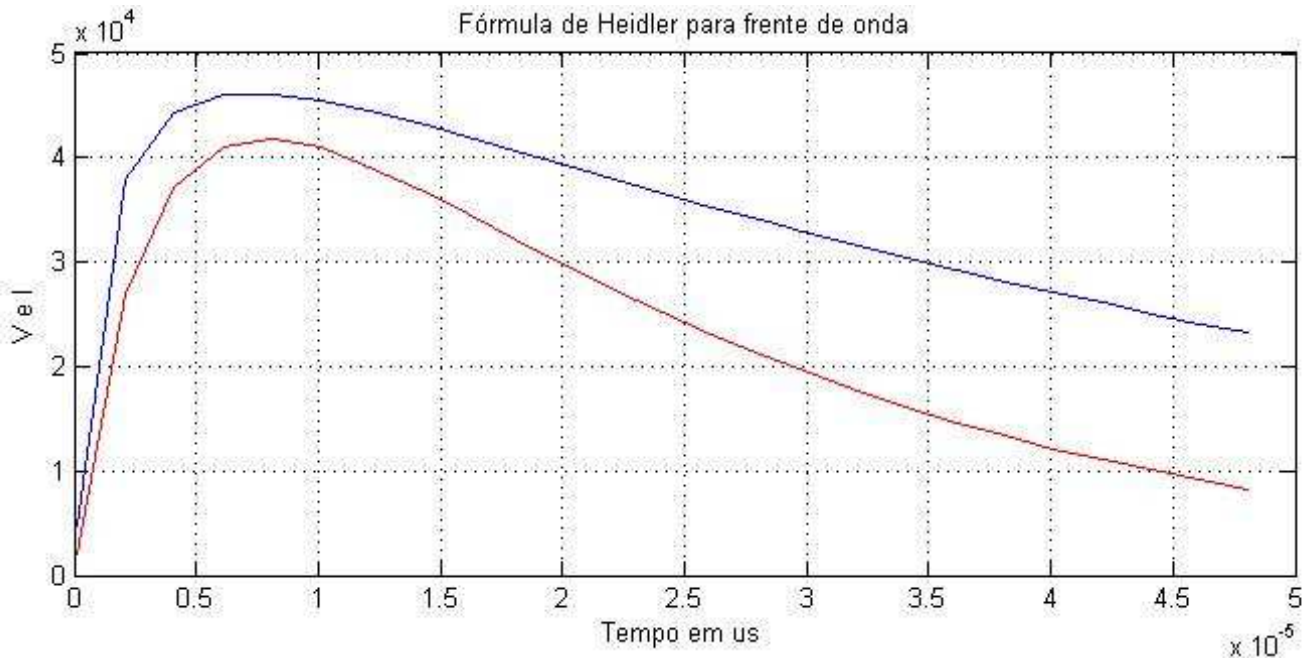

Figura 4.09 Simulação da função de Heidler

$C: \backslash M A T L A B \backslash$ work $\backslash$ fheidler_2.m

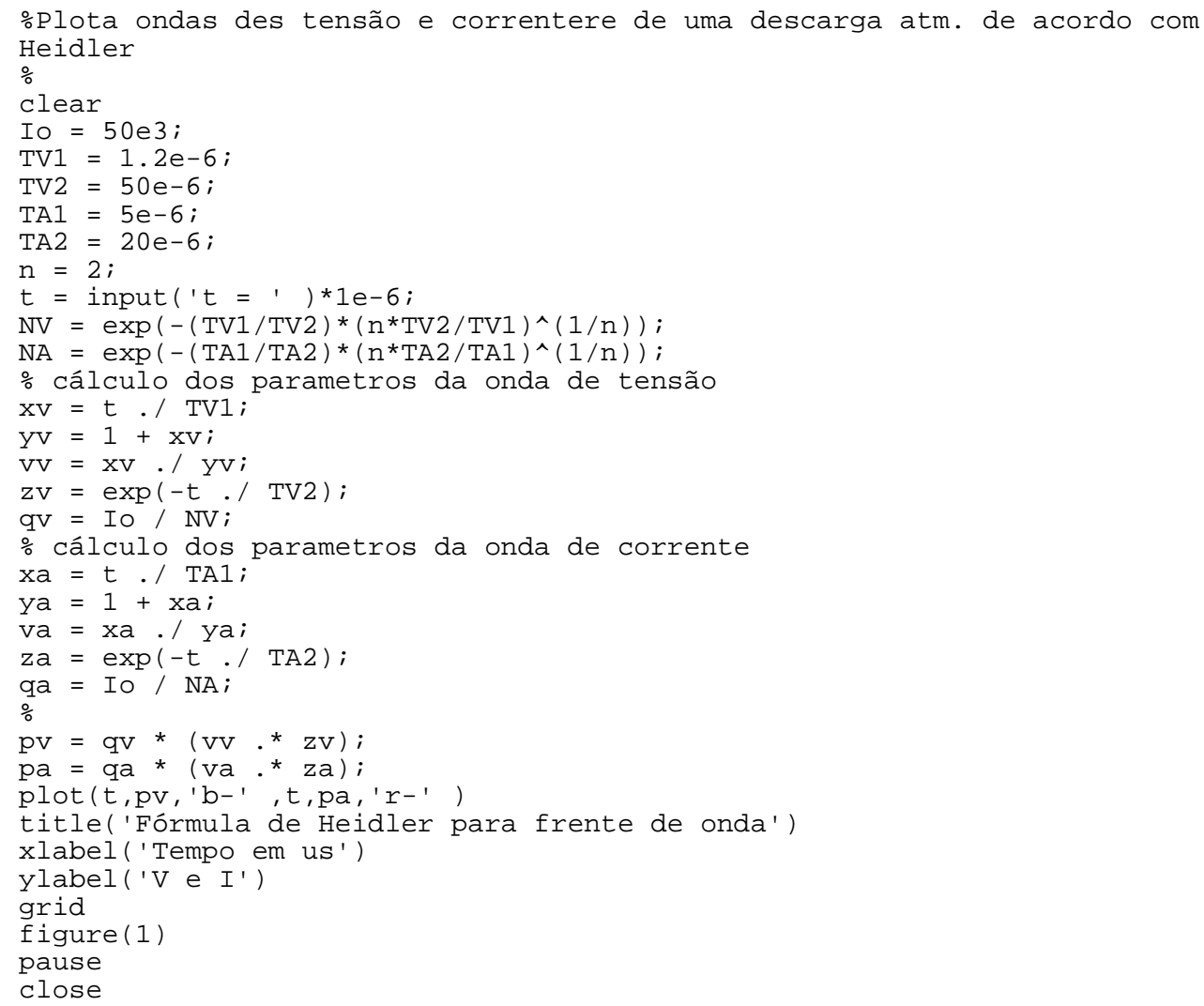




\section{5 - Roteiro de um projeto de proteção}

Com o objetivo de propiciar uma proteção contra descargas atmosféricas tanto a nível externo (SPDA), quanto interno, desenvolveu-se um roteiro de procedimentos a serem observados, focando instalações em baixa tensão [04]; Começando o projeto de fora para dentro, ou seja, pelo sistema captor (ou pára-raios) no topo da edificação até a equipotencialização, aterramento e instalação de outros equipamentos de proteção.

Para tanto, considerou-se hipoteticamente uma casa de $150 \mathrm{~m}^{2}$, telhado com duas águas, com uma antena de TV instalada na cumeeira do telhado e que pelo cálculo do risco desse como $10^{-3}>\mathrm{N}_{\mathrm{c}}>10^{-6}$, ou seja, ficaria por conta do projetista ou proprietário a instalação de um SPDA.

Captação - Como toda peça metálica instalada nessa posição, ela torna-se um captor natural; se não estiver aterrada, um raio eventualmente captado (direta ou indiretamente) irá descer pelo cabo da antena, terminando em plena sala de estar, não apenas destruindo o aparelho de TV, mas podendo até causar algum dano físico aos presentes no local no momento do fato. Portanto, a $1^{\text {a }}$ providência será aterrar a antena. Mesmo com a antena devidamente aterrada, ainda haverá uma sobretensão induzida no cabo da antena; não causará mais perigo aos habitantes da casa, mas ainda poderá danificar o aparelho.

Como já observado neste capítulo, qualquer corpo ou perfil metálico de altura suficiente torna-se um captor, não sendo necessário adotar soluções pretensamente mais sofisticadas - e seguramente mais caras - como pontas múltiplas e outras do gênero. Por motivos estéticos, pode-se fazer um captor com a mesma base e tubo central da antena existente, ou seja, utilizaremos uma antena 'pelada', do mesmo fabricante. Esta base pode ser posteriormente usada como suporte para uma antena de UHF, FM, PX, rádio-amador, etc. ou mesmo uma antena parabólica, já que a estrutura central estará devidamente aterrada.

Descidas - Além de interligar as duas antenas (conforme a norma NBR 5419/2005 especifica) instalar duas descidas, o mais afastadas e simétricas possível em relação à construção. Para o material de descida, utilizar cabo de cobre seção $16 \mathrm{~mm}^{2}$ ou cabo de aço galvanizado de seção $50 \mathrm{~mm}^{2}$. Para a conexão com a antena, utilizar um conector de dois parafusos M8. Na interligação, usar cabo de $35 \mathrm{~mm}^{2}$ e conector parafusado. 
Não é necessário espaçar as descidas da parede, mas é conveniente fixá-las de algum modo. Sendo usual embutir as descidas num tubo de PVC, para proteção mecânica (ao contrário do que muitos pensam, a isolação fornecida pelo PVC é desprezível) quando próximas ao solo.

Aterramento - $\mathrm{O}$ aterramento mais eficiente é o constituído por um cabo enterrado horizontalmente, em forma de anel, contornando a construção e interligando todas as descidas. No final de cada descida, conectar a uma haste de aterramento.

Para a conexão da descida com a haste, existem conectores apropriados, de bronze, com um parafuso de fixação. Para facilitar a verificação, medições e manutenção, deve-se fazer um pequeno "poço de inspeção" ao redor dessa conexão - por exemplo, uma caixa em tijolos.

Barra de equipotencialização - A partir da haste mais próxima da caixa de distribuição interna até esta, instalar um cabo de cobre e conectá-lo a uma barra de cobre, igual à que, provavelmente, já existe na caixa para interligação dos neutros.

À esta barra, chamada barra de equipotencialização, interligar os cabos terra das proteções instaladas nas linhas de força e de dados dos equipamentos internos, bem como também pode ser utilizada para conexão dos cabos terra de máquinas de lavar roupa, fornos de microondas, etc. Não esquecer de interligá-la com a barra dos neutros, caso exista, e não esteja o neutro aterrado em outro ponto.

Aterramento das linhas de força - Todos os equipamentos eletrônicos mais sensíveis têm um $3^{\circ}$ fio para ser ligado à terra, seja através de um cabo externo, seja um terceiro pino no "plug". Normalmente, este fio é desprezado, sujeitando o equipamento a sobretensões no caso de surtos na linha, causados por raios ou atuação de fusíveis, disjuntores e interruptores. É recomendável instalar um fio terra desde a barra de terra até os respectivos equipamentos, mesmo à custa de algum sacrifício estético.

\section{6 - História da Norma NBR 5419}

A primeira versão da NBR 5419 foi publicada em 1977, mas antes disso a extinta NB 1-65, publicada na década de 1970, já oferecia parâmetro para a instalação de páraraios, no entanto, as condições eram incompletas e com base em uma norma belga, já que naquela ocasião o Brasil não tinha tanta ligação com a IEC. 
A primeira revisão da norma só aconteceu em 1993, ou seja, 16 anos após a publicação da primeira versão, e representou a principal modificação até o momento em seu documento, quando passou, efetivamente, a basear-se na IEC 62305. Entre as inúmeras alterações implantadas nesse período, Normando Alves, da Termotécnica, destaca a inclusão dos métodos Faraday e eletrogeométrico.

Até então, o único método permitido era o Franklin. Além disso, vieram à tona questões como a equalização, de proteção contra surtos e o valor da parada em razão de uma descarga atmosférica. Outra revisão aconteceu em 2001 e nela foram feitas correções de inúmeros termos que passaram erroneamente na revisão de 1993. Foram corrigidos erros de ortografia, gramática, terminologias e unidades equivocadas.

\section{7 - O Processo de Revisão da Norma}

A norma de proteção de estruturas contra descargas atmosféricas (NBR 5419) está prestes a passar por uma significante modificação. A norma, que já passou por três revisões desde sua primeira versão, publicada em 1977, tende cada vez mais a se aproximar do conteúdo da norma na qual é baseada, a IEC 62305.

Para isso, a cada nova atualização da norma internacional, o grupo de estudo se reúne para rever conceitos e adaptar a norma brasileira. A preocupação com a adequação dos pára-raios das edificações não acontece por acaso. O Brasil é campeão de descargas atmosféricas no mundo, contabilizando 60 milhões por ano. [36]

O novo documento deverá entrar em vigor em 2009, segundo estimativa do membro da Comissão de Estudos (CE) que avalia a revisão da norma, o engenheiro mecânico eletricista, diretor da Encontre Engenharia, Duílio Moreira Leite. Porém, a eficiência da norma na prática ainda esbarrará em uma dificuldade enfrentada pelas principais normas do setor elétrico: a falta de fiscalização, que é responsabilidade da prefeitura de cada município.

As modificações da revisão serão impactantes em um primeiro momento, considerando a quantidade e a complexidade das alterações. Para se ter uma idéia, a norma, que atualmente possui 48 páginas, passará a ter cerca de 200 após a revisão, conforme estima o relator da NBR 5419/2001 e membro da comissão que estuda a revisão da norma, o diretor-técnico da empresa Termotécnica, Normando Alves. “A revisão representará um 
grande pulo em termos de quantidade de folhas e as pessoas terão um pouco de dificuldade em um primeiro momento para lidar com a norma", avalia.

Tais dificuldades serão superadas, segundo ele, com a participação em cursos e palestras de atualização que são rotineiramente oferecidos para projetistas, engenheiros e fiscais por empresas e entidades do setor, como a Associação Brasileira de Normas Técnicas (ABNT), o CREA, entre outras.

Ressalta-se que qualquer pessoa pode participar da elaboração de uma norma, desde que tenha conhecimento técnico para isso.

Artigo retirado do Portal Lumière [32] entitulado: NBR 5419: Vem aí uma nova norma para aterramento. 


\section{PROTEÇÃO INTERNA}

No capítulo anterior, retratar as formas de se proteger construções de ações externas e diretas das descargas atmosféricas foi o principal foco. Como definido pela NBR 5419/2005, um SPDA, a princípio, não se preocupa com a proteção interna à construção. Antes, seus subsistemas trabalham em conjunto para garantir que os efeitos de uma descarga direta (ou indireta) não se propaguem para dentro da construção, proporcionando para as sobrecorrentes e sobretensões um caminho de rápido escoamento para a terra. Neste capitulo mostra-se as opções de proteção interna à construção. Ou seja, subsistema de aterramento, de equalização de potenciais e protetores especiais.

Apresentam-se os parâmetros e objetivos de cada um destes subsistemas, cálculos relacionados e fechando com um pequeno comentário sobre Qualidade de Energia Elétrica (QEE).

\section{1 - Aterramento}

Um aterramento elétrico significa uma ligação elétrica proposital de um sistema físico (elétrico, eletrônico, ou corpo metálico) ao solo.

Desse modo, podemos definir um "Terra Elétrico" como um ente idealizado, capaz de fornecer ou absorver a quantidade de carga elétrica que se fizerem necessárias à situação sem, entretanto, alterar quaisquer de suas propriedades elétricas, e mostrando-se sempre eletricamente neutro ao ambiente que o cerca [23].

Podemos classificar um sistema de aterramento de acordo com o alvo (ou objetivo) a ser protegido:

- Segurança ou proteção: São os sistemas nos quais partes metálicas não energizadas das instalações são conectadas visando evitar acidentes, no caso dessas serem acidentalmente energizadas. Tais sistemas são projetados para limitar os potenciais produzidos durante o fluxo de corrente para a terra e visam a segurança dos seres vivos (homens e animais). 
- Serviço ou Funcional: São os sistemas que fazem parte integrante dos circuitos elétricos onde um condutor, geralmente o neutro, é conectado e visa garantir a utilização correta e confiável da instalação. Exemplo: aterramento contra descargas atmosféricas.

Deve-se ter em mente que um caminho efetivo de aterramento deve:

$>$ Ser permanente e contínuo;

$>$ Ter capacidade para conduzir com segurança qualquer corrente de falta imposta ao sistema;

Ter impedância baixa o suficiente para limitar a tensão contra a terra e para facilitar a operação dos dispositivos de proteção dos circuitos.

- Controle de ruído elétrico: O principal objetivo do aterramento para o controle do ruído elétrico é criar um sistema de aterramento equipotencial. As diferenças de potencial entre pontos do sistema de aterramento podem prejudicar o isolamento, criar correntes circulantes em cabos de baixa tensão, e interferir com equipamentos sensíveis.

- Proteção contra descargas atmosféricas - Garantindo o escoamento direto a terra.

O ponto do sistema que se deseja conectar ao solo pode variar. Dependendo da aplicação, este pode ser uma trilha numa placa de circuito impresso, na carcaça de um motor, ou no neutro de um sistema elétrico.

Os eletrodos de aterramento também podem ter configurações diversas. Como conceitualmente o eletrodo é qualquer corpo metálico enterrado no solo, além das configurações usuais como cantoneiras de ferro galvanizado, sistemas hidráulicos, etc. podemos ainda utilizar a própria malha estrutural (a sua ferragem) de uma edificação como eletrodo (mas apenas se este caso foi planejado no projeto). Deve-se enfatizar isto pois se não foi considerado ainda na época do projeto estrutural da edificação o uso da ferragem como malha de aterramento, não se deve ligar o fio terra do aparelho a esta malha.

Assim como também a forma e a disposição geométrica são variadas, de acordo com a aplicação. As hastes verticais são muito usadas, principalmente, quando as camadas mais profundas do solo têm menor resistividade e pela simplicidade de instalação. Os 
eletrodos horizontais, enterrados usualmente a $50 \mathrm{~cm}$, são usados principalmente quando a maior preocupação é o controle do gradiente de potencial na superfície do solo (veremos mais detalhadamente quando tratarmos da equipotencialização).

Qualquer que seja sua finalidade (proteção ou funcional), o aterramento deve ser único em cada instalação. Ou seja, deve-se evitar aterramentos isolados para diferentes aparelhos eletro-eletrônicos da construção. Se o sistema de dada construção tem esta configuração, deve-se interligar as hastes dos diversos aterramentos.

Para casos específicos de acordo com as prescrições da instalação, podem ser usados separadamente (falaremos sobre isto quando tratarmos de configurações de equipotencialização), desde que sejam tomadas as devidas precauções. A seleção e instalação dos componentes dos aterramentos devem ser tais que:

1. O valor da resistência de aterramento obtida não se modifique consideravelmente ao longo do tempo;

2. Resistam às solicitações térmicas, termomecânicas e eletromecânicas;

3. Sejam adequadamente robustos ou possuam proteção mecânica apropriada para fazer face às condições de influências externas.

Devem ser tomadas precauções para impedir danos aos eletrodos e a outras partes metálicas por efeitos de eletrólise. Um sistema de aterramento é composto de três partes principais:

- As conexões elétricas que ligam um ponto do sistema aos eletrodos;

- Eletrodos de aterramento - basicamente pode ser qualquer corpo metálico de boa condutividade colocado no solo;

- Terra envolvendo os eletrodos.

\subsection{1 - A Resistência de aterramento}

Para se avaliar a natureza do aterramento, devemos considerar o valor da resistência de aterramento, que é um parâmetro utilizado para se medir a eficiência do sistema, ou seja, a capacidade de condução da corrente para a terra. 
Para assegurar a dispersão da corrente de descarga atmosférica na terra sem causar sobretensões perigosas, o arranjo e as dimensões do sistema de aterramento são mais importantes que o próprio valor da resistência de aterramento. Entretanto, a NBR $5419 / 2005$ recomenda uma resistência da ordem de $10 \Omega$, como forma de reduzir os gradientes de potencial no solo e a probabilidade de centelhamento perigoso.

Uma conexão à terra apresenta resistência, capacitância e indutância, cada qual influindo na capacidade de condução de corrente para o solo. Dito isto, o mais correto seria considerar uma impedância de aterramento. No entanto, para operações de baixa frequiência, e cuja impedância de aterramento seja superior a $1 \Omega$, pode-se desprezar os efeitos capacitivo e indutivo, de modo que a impedância de aterramento comporta-se como uma resistência linear.

Para aplicações envolvendo alta freqüência (como sistemas de telecomunicações e ondas impulsivas de corrente e tensão originadas de descargas atmosféricas), deve-se considerar o efeito capacitivo e a influência da reatância indutiva sobre os condutores e eletrodos [01].

Pode-se definir a resistência de aterramento $\left(\mathrm{R}_{\mathrm{T}}\right)$ como a medida entre as faces opostas de um cubo unitário (aresta $l$ de $1 \mathrm{~m}$ ) preenchido com este solo.

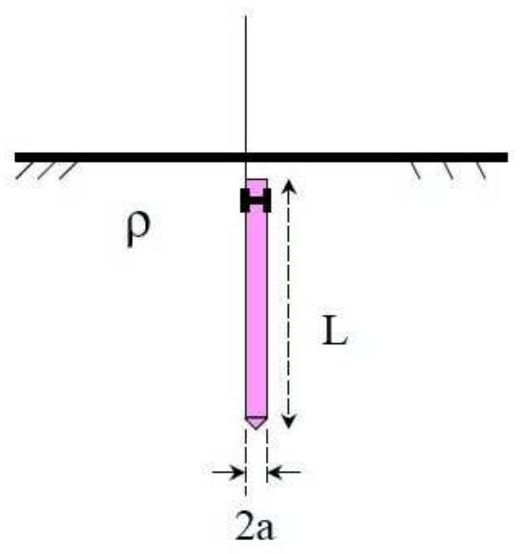

$$
R_{T}=\frac{\rho}{2 . \pi \cdot L} .\left(\ln \frac{4 . L}{a}-1\right)
$$

Figura 5.01 Cálculo do valor da resistência de aterramento [02]

Comercialmente, os comprimentos (L) e diâmetros (2a) mais comuns são 2,4 e 3 m e 1/2, 3/4 e 1 polegadas, respectivamente.

O solo em seu estado natural é um mau condutor de eletricidade. Se for considerado totalmente seco, ele se comporta como um material isolante. $\mathrm{O}$ aumento do número de hastes 
(bastões) e de sua configuração aumentam a eficiência do sistema consideravelmente. Além disso, há outros fatores que podem ser observados na montagem do sistema, para se alcançar os valores dentro da norma ou próximo deles.

Pela expressão na figura 5.01 pode-se concluir que quanto maior o comprimento da haste menor a resistência de aterramento, isto porque quanto maior a haste maior a superfície de passagem da corrente, diminuindo assim a resistência (vale salientar que usar a haste enterrada horizontalmente apresenta melhores resultados que fincados na vertical).

O diâmetro tem importância praticamente irrelevante, uma vez que a resistência depende do seu logaritmo, seus valores em media não ultrapassam $25 \mathrm{~mm}$.

A ligação de hastes em paralelo reduz a resistência de aterramento. Neste caso, para que seja utilizada plenamente a possibilidade de dispersão da haste é necessário cravá-la fora da zona de dispersão da outra, ou seja, na região de potencial nulo. È comum utilizar o afastamento entre hastes igual ou superior ao seu comprimento. Para distâncias menores, a eficiência das hastes é bastante reduzida. Desta forma, duas hastes que isoladamente dariam resistências de aterramento de $10 \mathrm{ohms}$, quando colocadas em paralelo a uma distancia de 15 m darão uma resistência total de mais ou menos 5ohms; se a distância for de $10 \mathrm{~m}$ a resistência total será mais ou menos 7 ohms.

A figura 5.02 mostra que a eficácia cresce na proporção direta ao número de hastes: assim, com duas hastes a resistência cai pela metade, com quatro tende a se reduz a um quarto, etc.

Já na figura 5.03, verifica-se uma redução na eficiência, uma vez que uma haste está na zona de dispersão da outra. Para mais de duas hastes a analise é análoga.

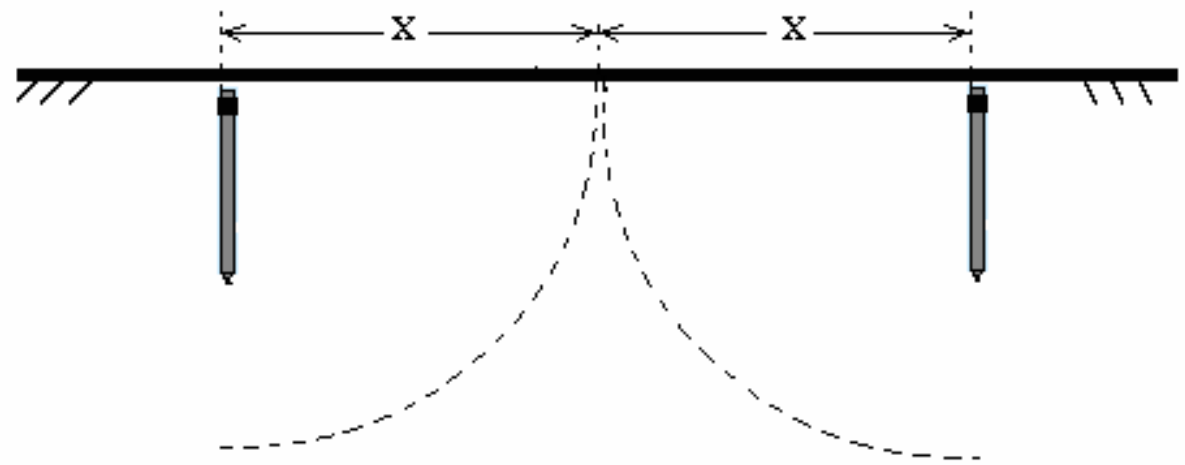

Figura 5.02 Eficiência máxima [02] 


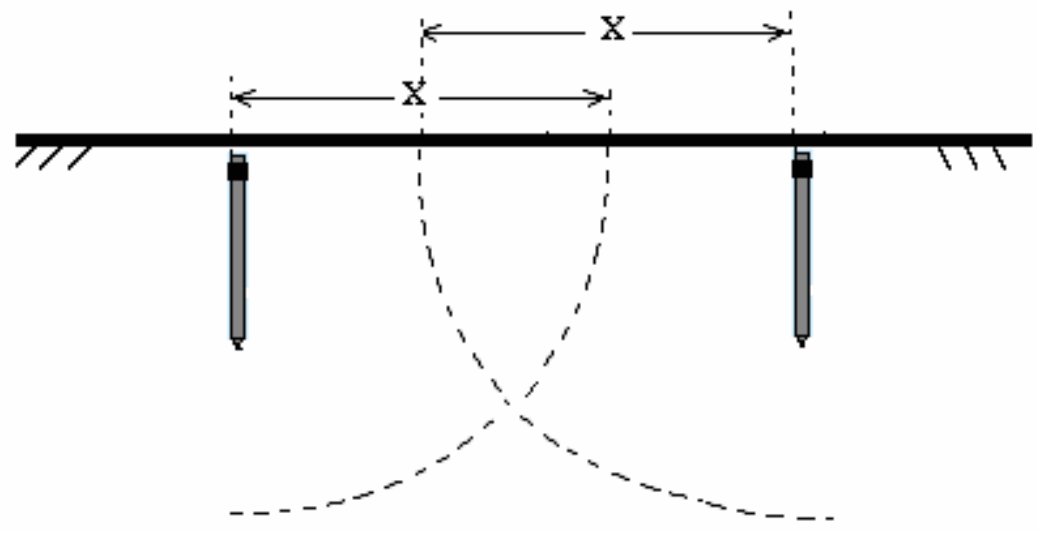

Figura 5.03 Eficiência reduzida [02]

Posto isto, percebeu-se que a uma boa firma (além de ser a mais conhecida e praticada) de redução da resistência de aterramento seja pelo aumento no número de hastes, como também sua posição (forma) com relação ao objeto a se proteger. No entanto, dependendo do tipo de solo da região, pode acontecer que mesmo utilizando várias hastes não se atinja o valor mínimo normatizado. No Anexo A, podes verificar uma tabela com configurações típicas de sistemas de aterramento.

\subsection{2 - A resistividade do solo}

Os tipos de solo não são claramente definidos. Por isto, não é possível atribuir-se um valor específico de resistividade a um tipo de solo. Além disso, a experiência mostra que, usualmente, são encontrados valores diferentes de resistividade para a mesma variedade de solo de localidades distintas.

Contudo, é possível caracterizar faixas de valores característicos para os diferentes tipos de solo, nas suas condições usuais de umidade, conforme compilado na tabela abaixo.

Tabela 5.01 Faixa de valores usuais de resistividade [01]

\begin{tabular}{|c|c|}
\hline Tipo de solo & 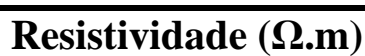 \\
\hline$\overline{\text { Lama }}$ & 5 a 100 \\
\hline Húmus & 10 a 150 \\
\hline Limo & 20 a 100 \\
\hline Argila & 80 a 330 \\
\hline
\end{tabular}




\begin{tabular}{|l|c|}
\hline Terra de jardim & 140 a 480 \\
\hline Calcário fissurado & 500 a 1.000 \\
\hline Calcário compactado & 1.000 a 5.000 \\
\hline Granito & 1.500 a 10.000 \\
\hline Areia comum & 3.000 a 8.000 \\
\hline Basalto & 10.000 a 20.000 \\
\hline
\end{tabular}

\subsection{3 - Umidade do solo}

Para entender o efeito da umidade na resistividade do solo, deve-se considerar que, em baixa frequiência, a condução no solo se dá basicamente por meios eletrolíticos. E para haver eletrólise é essencial a existência de água e dos sais que irão prover os íons necessários à reação.

Assim, a condutividade do solo é sensivelmente afetada pela quantidade de água nele contida, numa relação direta de aumento da umidade do solo resultando numa diminuição de sua resistividade.

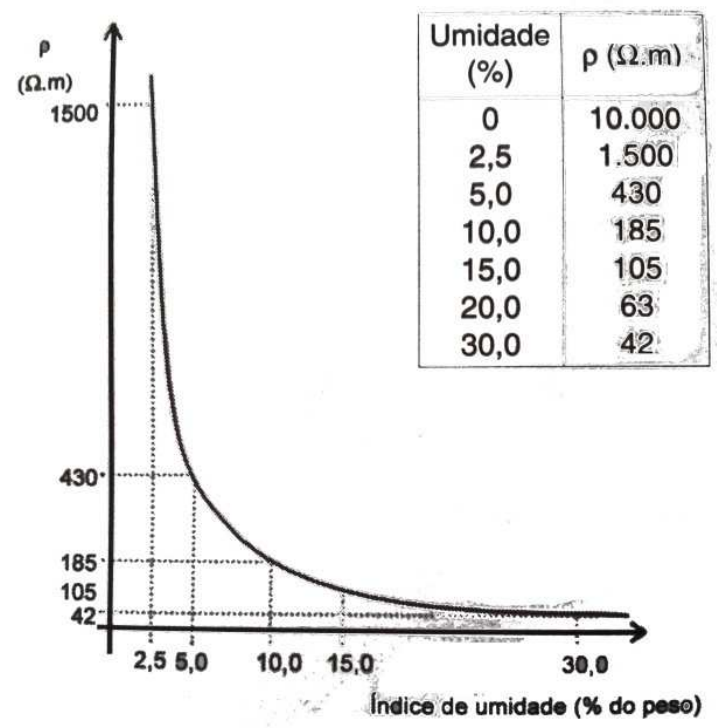

Figura 5.04 Índice de umidade [02]

A figura acima é um gráfico que estabelece a relação entre resistividade e umidade de um solo arenoso. Pode-se obeservar que a resistividade diminui sensivelmente com o 
aumento da quantidade de água diluída no solo. Experiências realizadas com diversos tipos de solo comprovaram que o comportamento da curva tende a se comportar da mesma forma, independente de qual seja ele.

\subsection{4 - Concentração de sais}

Sabendo-se que a resistividade do solo depende da quantidade de água retida nele, e ainda, que a resistividade da água é controlada pelos sais dissolvidos nela (condução eletrolítica), conclui-se que a resistividade do solo também é influenciada pela quantidade e tipos de sais dissolvidos na água.

A areia costuma ser pobre em sais minerais. Por isso, ao umidecer uma amostra de areia com água destilada, geralmente verifica-se que sua resistividade varia relativamente pouco, a despeito da variação da umidade.

A tabela abaixo mostra a relação entre a quantidade de sal adicionado a um solo arenoso, de umidade $15 \%$ (percentual por peso) e a uma temperatura ambiente de $17^{\circ} \mathrm{C}$, e sua resistividade.

Tabela 5.02 Influência da concentração de sais na resistividade do solo [01]

\begin{tabular}{|c|c|}
\hline $\begin{array}{c}\text { Sal adicionado } \\
(\% \text { em peso })\end{array}$ & $\boldsymbol{\rho}$ (solo arenoso) \\
\hline 0 & 107 \\
\hline 0,1 & 18 \\
\hline 1,0 & 1,9 \\
\hline 5,0 & 1,6 \\
\hline 10,0 & 1,3 \\
\hline 20,0 & 1,0 \\
\hline
\end{tabular}

A figura 5.05, ilustra a influência do tipo de sal dissolvido na água. 


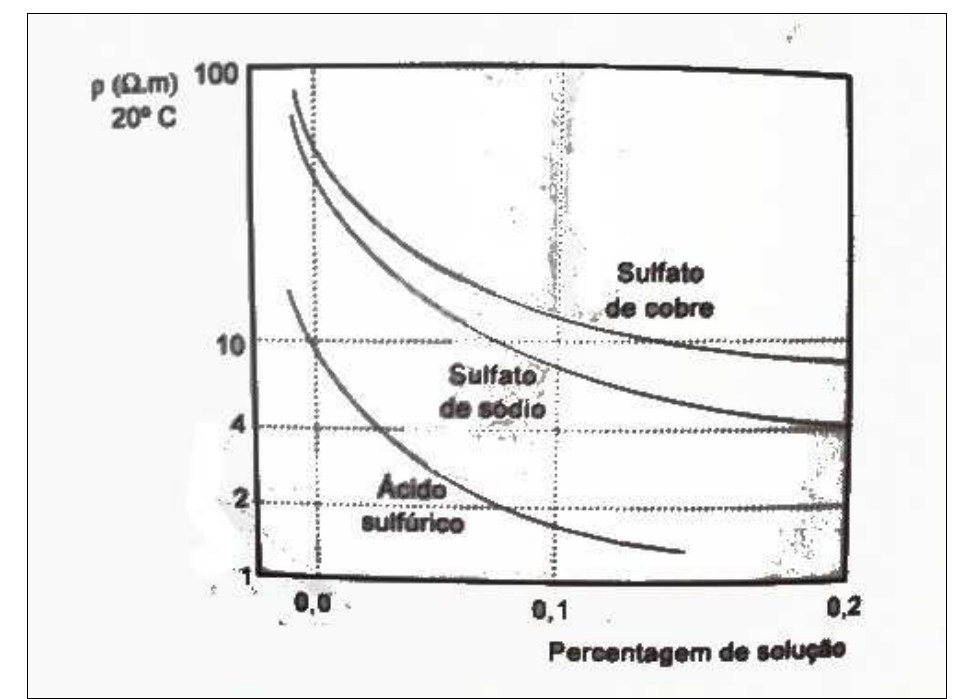

Figura 5.05: Efeito do tipo e concentração de sais na resistividade do solo [01]

Além desses fatores, há ainda outros que devem ser observados na constituição de um aterramento:

- Compacticidade do solo - Quanto mais compacto maior sua continuidade física, e consequentemente, menor sua resistividade;

- Granulometria do solo - A dimensão e a presença de diferentes grãos no solo tem influência na capacidade dele reter água e na continuidade do solo;

- Temperatura - Quanto maior a temperatura, maior a evaporação de água;

\subsection{5 - Outros elementos do aterramento}

O eletrodo de aterramento preferencial numa edificação é o constituído pelas armaduras de aço embutidas no concreto das fundações das edificações. [25]

A experiência tem demonstrado que as armaduras de aço das estacas, dos blocos de fundação e das vigas baldrames, interligadas nas condições correntes de execução, constituem um eletrodo de aterramento de excelentes características elétricas.

As armaduras de aço das fundações, juntamente com as demais armaduras do concreto da edificação, podem constituir, nas condições prescritas pela NBR 5419, o sistema de proteção contra descargas atmosféricas (aterramento e gaiola de Faraday, completado por um sistema captor). 
No caso de fundações em alvenaria, o eletrodo de aterramento pode ser constituído por uma fita de aço ou barra de aço de construção, imersa no concreto das fundações, formando um anel em todo o perímetro da estrutura. A fita deve ter, no mínimo, $100 \mathrm{~mm}^{2}$ de seção e $3 \mathrm{~mm}$ de espessura e deve ser disposta na posição vertical. A barra deve ter o mínimo $95 \mathrm{~mm}^{2}$ de seção. A barra ou a fita deve ser envolvida por uma camada de concreto com espessura mínima de $5 \mathrm{~cm}$.

Quando o aterramento pelas fundações não for praticável, podem ser utilizados os eletrodos de aterramento convencionais, indicados na tabela abaixo, observando-se que:

a) O tipo e a profundidade de instalação dos eletrodos de aterramento devem ser tais que as mudanças nas condições do solo (por exemplo, secagem) não aumentem a resistência do aterramento dos eletrodos acima do valor exigido;

b) O projeto do aterramento deve considerar o possível aumento da resistência de aterramento dos eletrodos devido à corrosão;

c) Preferencialmente o eletrodo de aterramento deve formar um anel circundando o perímetro da edificação;

d) A eficiência de qualquer eletrodo de aterramento depende das condições locais do solo; devem ser selecionados um ou mais eletrodos adequados às condições do solo e ao valor da resistência de aterramento exigida pelo esquema de aterramento adotado.

Tabela 5.03 Dimensão dos eletrodos convencionais [01]

\begin{tabular}{|c|c|c|}
\hline Tipo de eletrodo & Dimensões mínimas & Observações \\
\hline Tubo de aço zincado & $\begin{array}{l}2,40 \mathrm{~m} \text { de comprimento e diâmetro } \\
\text { nominal de } 25 \mathrm{~mm}\end{array}$ & Enterramento totalmente vertical \\
\hline Perfil de aço zincado & $\begin{array}{l}\text { Cantoneira de }(20 \mathrm{~mm} \times 20 \mathrm{~mm} \times \\
3 \mathrm{~mm}) \text { com } 2,40 \mathrm{~m} \text { de comprimento }\end{array}$ & Enterramento totalmente vertical \\
\hline Haste de aço zincado & $\begin{array}{l}\text { Diâmetro de } 15 \mathrm{~mm} \text { com } 2,00 \text { ou } \\
2,40 \mathrm{~m} \text { de comprimento }\end{array}$ & Enterramento totalmente vertical \\
\hline $\begin{array}{l}\text { Haste de aço revestida } \\
\text { de cobre }\end{array}$ & $\begin{array}{l}\text { Diâmetro de } 15 \mathrm{~mm} \text { com } 2,00 \text { ou } \\
2,40 \mathrm{~m} \text { de comprimento }\end{array}$ & Enterramento totalmente vertical \\
\hline Haste de cobre & $\begin{array}{l}\text { Diâmetro de } 15 \mathrm{~mm} \text { com } 2,00 \mathrm{ou} \\
2,40 \mathrm{~m} \text { de comprimento }\end{array}$ & Enterramento totalmente vertical \\
\hline
\end{tabular}




\begin{tabular}{|l|l|l|l|}
\hline Fita de cobre & $\begin{array}{l}25 \mathrm{~mm}^{2} \text { de seção, 2 } \mathrm{mm} \text { de } \\
\text { espessura e } 10 \mathrm{~m} \text { de comprimento }\end{array}$ & $\begin{array}{l}\text { Profundidade mínima de 0,60 m. Largura na } \\
\text { posição vertical }\end{array}$ \\
\hline $\begin{array}{l}\text { Fita de aço } \\
\text { galvanizado }\end{array}$ & $\begin{array}{l}100 \mathrm{~mm}^{2} \text { de seção, } 3 \mathrm{~mm} \text { de } \\
\text { espessura e } 10 \mathrm{~m} \text { de comprimento }\end{array}$ & $\begin{array}{l}\text { Profundidade mínima de 0,60 m. Largura na } \\
\text { posição vertical }\end{array}$ \\
\hline Cabo de cobre & $\begin{array}{l}25 \mathrm{~mm}^{2} \text { de seção e } 10 \mathrm{~m} \text { de } \\
\text { comprimento }\end{array}$ & $\begin{array}{l}\text { Profundidade mínima de 0,60 m. Posição } \\
\text { horizontal }\end{array}$ \\
\hline Cabo de aço zincado & $\begin{array}{l}95 \mathrm{~mm}^{2} \text { de seção e } 10 \mathrm{~m} \mathrm{de} \\
\text { comprimento }\end{array}$ & $\begin{array}{l}\text { Profundidade mínima de 0,60 m. Posição } \\
\text { horizontal }\end{array}$ \\
\hline Cabo de aço cobreado & $\begin{array}{l}50 \mathrm{~mm}^{2} \text { de seção e } 10 \mathrm{~m} \mathrm{de} \\
\text { comprimento }\end{array}$ & $\begin{array}{l}\text { Profundidade mínima de 0,60 m. Posição } \\
\text { horizontal }\end{array}$ \\
\hline
\end{tabular}

Canalizações metálicas de fornecimento de água e outros serviços não devem ser usadas como eletrodo de aterramento.

\subsubsection{2 - Condutores de aterramento}

Os condutores de aterramento devem atender às prescrições gerais.

Quando o condutor de aterramento estiver enterrado no solo, sua seção mínima deve estar de acordo com a tabela abaixo:

Tabela 5.04 Seções mínimas de condutores de aterramento [01]

\begin{tabular}{|c|c|c|}
\hline & Protegido mecanicamente & Não protegido mecanicamente \\
\hline Protegido contra corrosão & De acordo com 6.4.3.1 & $\begin{array}{l}\text { Cobre: } 16 \mathrm{~mm}^{2} \\
\text { Aço: } 16 \mathrm{~mm}^{2}\end{array}$ \\
\hline $\begin{array}{l}\text { Não protegido contra } \\
\text { corrosão }\end{array}$ & $\begin{array}{l}\text { Cobre: } 16 \mathrm{~mm}^{2} \text { ( solos ácidos ) } \\
25 \mathrm{~mm}^{2}(\text { solos alcalinos }) \\
\text { Aço: } 50 \mathrm{~mm}^{2}\end{array}$ & \\
\hline
\end{tabular}

Quando o eletrodo de aterramento estiver embutido nas fundações, a ligação ao eletrodo deve ser realizada diretamente, por solda elétrica, à armadura do concreto mais 
próxima, com seção não inferior a $50 \mathrm{~mm} 2$, preferencialmente com diâmetro não inferior a $12 \mathrm{~mm}$, ou ao ponto mais próximo do anel (fitas ou barra) embutido nas fundações. Em ambos os casos, deve ser utilizado um condutor de aço com diâmetro mínimo de $12 \mathrm{~mm}$, ou uma fita de aço de $25 \mathrm{~mm}$ x $4 \mathrm{~mm}$. Com o condutor de aço citado, acessível fora do concreto, a ligação à barra ou condutor de cobre para utilização, deve ser feita por solda exotérmica ou por processo equivalente do ponto de vista elétrico e da corrosão.

\subsubsection{3 - Terminal de aterramento principal}

Em qualquer instalação deve ser previsto um terminal ou barra de aterramento principal e os seguintes condutores devem ser a ele ligados:

a) condutor de aterramento;

b) condutores de proteção principais;

c) condutores de equipotencialidade principais;

d) condutor neutro, se disponível;

e) barramento de equipotencialidade funcional, se necessário;

f) condutores de equipotencialidade ligados a eletrodos de aterramento de outros sistemas (por exemplo, SPDA).

Quando forem utilizados eletrodos de aterramento convencionais, deve ser previsto, em local acessível, um dispositivo para desligar o condutor de aterramento. Tal dispositivo deve ser combinado ao terminal ou barra de aterramento principal, de modo a permitir a medição da resistência de aterramento do eletrodo, ser somente desmontável com o auxílio de ferramenta, ser mecanicamente resistente e garantir a continuidade elétrica.

\subsubsection{4 - Condutores de proteção}

A Seção mínima não deve ser inferior ao valor determinado pela expressão seguinte (aplicável apenas para tempos de atuação dos dispositivos de proteção que não excedam $5 s)$ : 


$$
S=\frac{\sqrt{I^{2} \cdot t}}{k}
$$

Onde:

'S' é a seção do condutor, em milímetros quadrados;

'I' é o valor (eficaz) da corrente de falta que pode circular pelo dispositivo de proteção, para uma falta direta, em ampères;

t é o tempo de atuação do dispositivo de proteção, em segundos;

Deve ser levado em conta o efeito de limitação de corrente das impedâncias do circuito, bem como a capacidade limitadora (integral de Joule) do dispositivo de proteção. ' $k$ ' é o fator que depende do material do condutor de proteção, de sua isolação e outras partes e das temperaturas inicial e final.

Quando forem utilizados dispositivos de proteção a sobrecorrentes para a proteção contra contatos indiretos, o condutor de proteção deve estar contido na mesma linha elétrica dos condutores vivos ou em sua proximidade imediata.

Quando for exigido um aterramento por razões combinadas de proteção e funcionais, as prescrições relativas às medidas de proteção devem prevalecer.

Ter um pára-raios instalado em uma residência não elimina a possibilidade de se ter prejuízos financeiros (decorridos da queima ou destruição de equipamentos eletrônicos). Isto porque pode acontecer de o projetista, eletricista ou quem quer que seja contratado para instalar o pára-raios não prever a equalização entre os potenciais do SPDA, das linhas de força, telefônica, etc. Apesar de as normas NBR 5419 e NBR 5410 frisarem a importância desta.

\subsection{1 - Sobretensões}

As sobretensões são subidas bruscas da tensão da rede elétrica, as quais causa defeitos nos equipamentos da nossa moradia ou negócio. Em alguns casos são destruídos imediatamente e noutros vão se deteriorando com o tempo, o que significa uma diminuição de sua vida útil.

Atualmente, existe um grande número de equipamentos eletro-eletrônicos nas residências (computadores, aparelhos de som, microondas, etc.), cada vez mais sofisticados 
e que necessitam de uma alimentação o mais constante possível (EES). Apesar destes equipamentos serem desenvolvidos já com uma folga que garanta seu funcionamento mesmo que a tensão de alimentação não seja a indicada, eles ainda continuam indefesos quanto a subidas bruscas e curtas de tensão.

As sobretensões podem ser classificadas em permanentes ou transitórias. Elas são ditas permanentes quando são de longa duração e apresentam (como o nome sugere) um aumento da tensão. Já as transitórias são picos de tensão muito elevados e de muito curta duração, que podem chegar a danificar os equipamentos antes mesmo de seus sistemas de proteção agirem (quando existem).

Como dito há duas formas básicas de ocorrência de sobretensões em residências devido a descargas atmosféricas. Por descarga direta - quando um raio atinge o captor de um pára-raios residencial, se não estiver devidamente instalado, a simples descida da corrente pelo cabo de descida, produzirá um campo magnético variável induzindo uma tensão em qualquer material condutor próximo a ele. Se acontecer de a intensidade de corrente for tão alta a ponto de romper a rigidez dielétrica do material que separe o cabo de descida "energizado" com o material condutor, ocorrerá um arco elétrico envolvendo ambos os corpos, o que pode vir a causar incêndios. O que pode ser caracterizado por centelhamento lateral.

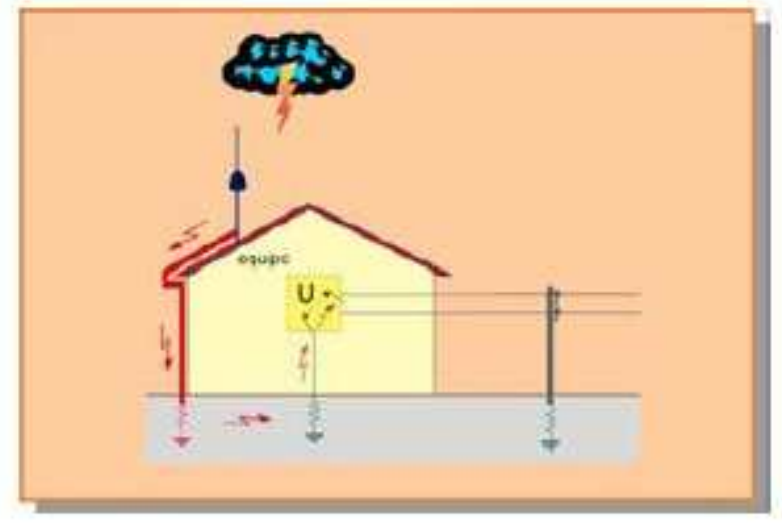

Figura 5.06 - Descida pelo captor [34]

Pode ser por ondas viajantes - quando um raio cai nas proximidades da rede de alimentação (ou diretamente sobre ela) ocorrerá uma onda de sobretensão (cujo seu valor é dividido por dois já que produzirá ondas nos dois sentidos). Se os sistemas de proteção desta linha não funcionarem, estas ondas "viajarão" até a residência e entrarão no sistema elétrico local. Se a residência não possuir um LEP (ligação equipotencial principal) onde 
todos os volumes metálicos estejam ligados a ele e este devidamente aterrado, todos os equipamentos ligados à rede residencial poderão ser danificados.

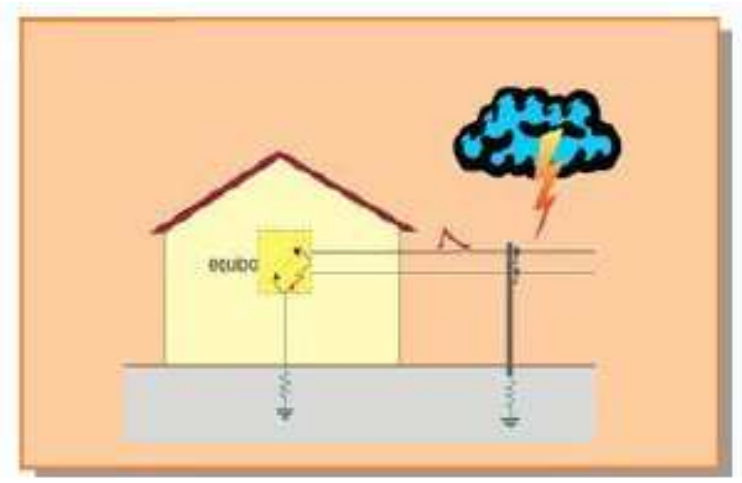

Figura 5.07: Descida pela rede [34]

Em ambos os casos pode ocorrer de o raio escolher caminhos que normalmente não estão devidamente protegidos como é o caso de linhas telefônicas ou TV-a-cabo (para o caso de tensões induzidas na rede) ou descidas pelo cabo da antena de TV (para o caso de impacto direto). E é justamente neste segundo ponto que iremos nos focar agora.

\subsection{2 - Sobretensões geradas por descargas atmosféricas}

De acordo com resultados obtidos em estudos realizados em vários países, as sobretensões originadas nas descargas atmosféricas são as mais severas e as de maior probabilidade de ocorrência. Um destes estudos, realizado na França, indicou que 84\% dos surtos são surtos rápidos. Isto num país onde a atividade atmosférica é bem menor do que no Brasil. [23]

- Nível ceraúnico médio em Minas Gerais: 80 dias de trovoada por ano;

- Nível ceraúnico médio na França: 30 dias de trovoada por ano.

Uma das técnicas mais eficazes na proteção elétrica é a equalização de potenciais. Se fosse possível manter todos os equipamentos e componentes de uma residência (ou um laboratório, central telefônica, etc.) no mesmo potencial, quando a mesma fosse atingida por 
uma descarga atmosférica ou surto elétrico, não haveria circulação de correntes entre eles e portanto não teríamos problemas de queima.

Como forma de melhor entender este princípio, a figura abaixo mostra um barco transportando vários equipamentos sendo atingido por uma onda. Como todos os equipamentos e cargas do barco, juntamente com este irão subir conjuntamente, não haverá "diferenças de potencial" entre os equipamentos e também entre o barco e os equipamentos.

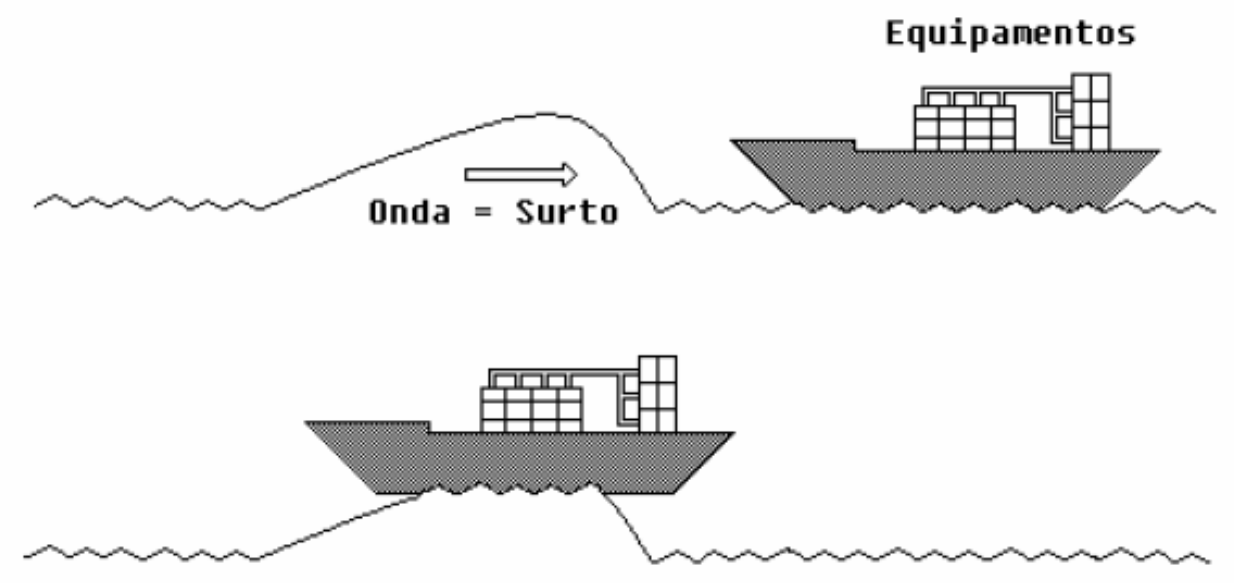

Figura 5.08: Elevação de potencial [23]

Se as residências fossem formadas por placas de metal como paredes e não tivessem cabos saindo delas, elas se comportariam como o barco diante da onda, e todos os equipamentos eletrônicos estariam seguros.

\subsection{3 - Equipamentos Eletrônicos Sensíveis (EES)}

As prescrições aqui contidas tratam do aterramento e das ligações equipotenciais dos equipamentos de tecnologia da informação e de equipamentos similares que necessitam de interligações para intercâmbio de dados. Podendo também serem utilizadas para outros equipamentos eletrônicos suscetíveis a interferências.

O termo "equipamento de tecnologia da informação" é usado pela IEC para designar todos os tipos de equipamentos elétricos e eletrônicos de escritório e 
equipamentos de telecomunicação. São exemplos de equipamentos aos quais prescrições podem ser aplicáveis:

- Equipamentos de telecomunicação e de transmissão de dados, equipamentos de processamentos de dados ou instalações que utilizam transmissão de sinais com retorno à terra, interna ou externamente ligadas a uma edificação;

- Fontes de corrente contínua que alimentam equipamentos de tecnologia da informação no interior de uma edificação;

- Equipamentos e instalações de CPCT- Central Privada de Comutação Telefônica $(\mathrm{PABX})$

- Sistemas CAM (Computer Aided Manufacturing) e outros que utilizam computadores.

\subsection{4 - Malha interna de equalização}

As regras mais importantes para se garantir uma boa equalização de potenciais são evitar loops nos cabos e o aterramento de um equipamento deve ser feito com o menor comprimento de cabo possível.

Para se conseguir uma boa equalização de potenciais necessita-se de um sistema que mantenha a antena, os cabos da antena, os equipamentos e a fiação interna e externa em um mesmo potencial.

Como envolver todo o sistema por uma caixa metálica é economicamente inviável, pode-se obter um efeito parecido com o da caixa, utilizando-se um sistema de aterramento interno ao cubículo e um sistema externo.

Existem algumas filosofias básicas para se aterrar equipamentos que estão distribuídos em um mesmo espaço físico. A figura 5.09 ilustra as filosofias mais utilizadas para a obtenção de uma boa equalização dentro do cubículo. 


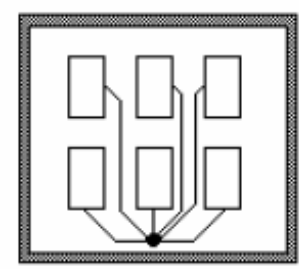

"Star-IBN" Estrela

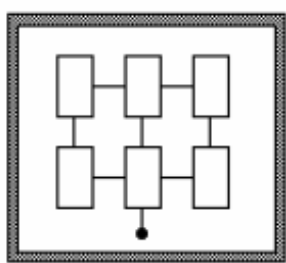

"Mesh-IBN"

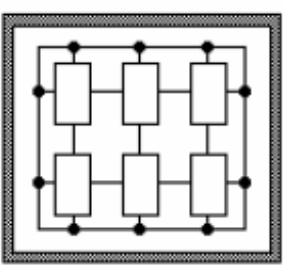

"Mesh-BN"

Malha Densa

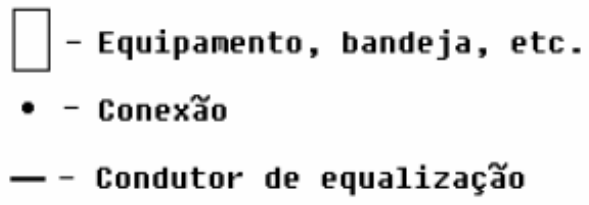

Figura 5.09: Filosofias de aterramento [23]

\subsection{5 - Ligação equipotencial}

A equipotencialização dos potenciais elétricos consiste na interligação das malhas de aterramento e tubulações metálicas com o sistema de pára-raios. A equalização de potenciais deve ser executada no nível do solo e sendo interligadas na caixa de equalização (TAP) ou LEP (caixa com barramento de cobre), de modo que todas as malhas de aterramento (elétrico, telefônico, computadores, interfone etc.) e todas as prumadas metálicas ( trilhos de elevadores, incêndio, recalque, gás, eletrocalhas etc.), normalmente colocada na entrada de energia da edificação exatamente para no caso de uma sobretensão vinda da rede de energia, esta, escoar para a terra.

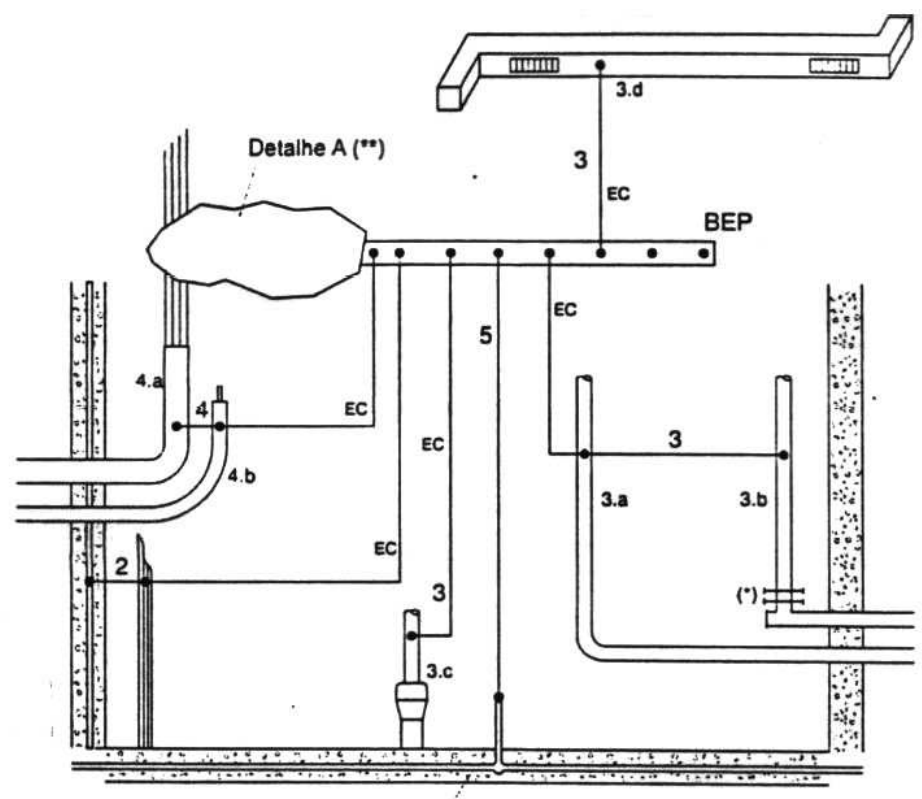

Figura 5.10: Barra de equipotencialização [02] 
O objetivo desta equalização é evitar tensões de contato perigosas em caso de faltas fase-massa internas ou externas ao prédio. Analogamente, uma equalização de potencial contra descargas atmosféricas destina-se a eliminar o risco de descargas laterais provocadas pelos raios. Esta segunda modalidade de equalização contempla medidas adicionais para instalações particularmente expostas a descargas atmosféricas (como antenas).

A ligação equipotencial pode incluir condutores, capas metálicas de cabos e partes metálicas da edificação, tais como tubulações de água e eletrodutos ou uma malha instalada em cada pavimento ou em parte de um pavimento. É conveniente incluir as armaduras do concreto da edificação na ligação equipotencial.

As características das ligações equipotenciais por razões funcionais (por exemplo, seção, forma e posição dos condutores) dependem da gama de frequiência dos sistemas de tecnologia da informação das condições presumidas para o ambiente eletromagnético e das características de imunidade/freqüência dos equipamentos.

\subsection{6 - Condutor PEN}

Nos esquemas TN, quando o condutor de proteção tiver uma seção maior ou igual a $10 \mathrm{~mm}^{2}$ em cobre ou a $16 \mathrm{~mm}^{2}$ em alumínio, nas instalações fixas, as funções de condutor de proteção e de condutor neutro podem ser combinadas, desde que a parte da instalação em referência não seja protegida por um dispositivo a corrente diferencial-residual. No entanto, a seção mínima de um condutor PEN pode ser de $4 \mathrm{~mm}^{2}$, desde que o cabo seja do tipo concêntrico e que as conexões que garantem a continuidade sejam duplicadas em todos os pontos de conexão ao longo do percurso do condutor periférico. O condutor PEN concêntrico deve ser utilizado desde o transformador e limitado a uma instalação que utilize acessórios adequados.

O condutor PEN deve ser isolado para as tensões a que possa ser submetido, a fim de evitar fugas de corrente.

Se, a partir de um ponto qualquer da instalação, o neutro e o condutor de proteção forem separados, não é permitido religá-los após esse ponto. No ponto de separação, devem ser previstos terminais ou barras separadas para o condutor de proteção e o neutro. O condutor PEN deve ser ligado ao terminal ou barra previsto para o condutor de proteção. 
Os condutores de equipotencialidade da ligação equipotencial principal devem possuir seções que não sejam inferiores à metade da seção do condutor de proteção de maior seção da instalação, com um mínimo de 6 mm².

Em edificações que abriguem ou estejam previstas para abrigar instalações de tecnologia da informação e telecomunicações, deve-se considerar o uso de condutor de proteção (PE) e condutor neutro $(\mathrm{N})$ separados, desde o ponto de entrada da alimentação.

Esta prescrição tem por objetivo reduzir ao mínimo a possibilidade de ocorrência de problemas de compatibilidade eletromagnética e, em casos extremos de sobrecorrente, devidos à passagem de correntes de neutro nos cabos de transmissão de sinais.

\section{3 - Compatibilidade Eletromagnética}

O estudo da compatibilidade eletromagnética nasceu, como muitas outras tecnologias, no âmbito militar. Para ser mais exato, nasceu devido aos PEM gerados pelas bombas nucleares lançadas no Japão, que deixaram vários navios sem comunicação durante semanas devido ao despreparo (ou incompatibilidade) destes equipamentos frente a um PEM.

Apesar da interferência eletromagnética estar presente, pode haver Compatibilidade Eletromagnética entre os equipamentos. Compatibilidade Eletromagnética significa que um dispositivo é compatível elétrica e magneticamente com o meio externo e interno. Ou seja, não existindo influência de um equipamento sobre o outro.

\section{4 - Qualidade de Energia Elétrica}

Sabe-se que muitos dos problemas relacionados com QEE têm a ver com aterramento e condutores em geral. Em eventos relacionados com QEE, é normalmente reportado que $80 \%$ de todos os problemas de QEE comunicados pelas empresas, em suas instalações, são devidos a aterramentos e condutores. Embora não existam bases científicas para garantir o percentual de $80 \%$, muitos dos problemas de QEE são resolvidos simplesmente apertando uma conexão frouxa ou substituindo um condutor danificado. 
Entretanto, uma revisão das técnicas referentes a aterramento e condutores é necessária como primeiro passo para a avaliação de problemas com QEE em geral. [05]

Pode-se definir a QEE em função de quatro perturbações elétricas básicas em um sinal de tensão ou corrente, presentes em uma instalação elétrica: amplitude da tensão, frequiência do sinal, desequilíbrios de tensão e corrente nos sistemas trifásicos e distorções na forma de onda do sinal. Sob o ponto de vista do nível de qualidade de energia elétrica fornecida pelo sistema da concessionária, é muito importante a ausência relativa de variações de tensão, particularmente a ausência de desligamentos. Já para o consumidor comum, o termo "qualidade de energia elétrica" está, na maioria das vezes, relacionado à ausência relativa de variações de tensão medidas no ponto de entrega de energia.

No Brasil, a ABNT e as Concessionárias de Energia provêem as normas mínimas para aterramento e condutores, sendo seguidamente necessário ir além dos requisitos destas normas para que se tenha um sistema no qual também se minimize o impacto das variações de QEE (harmônicas, transitórios, ruídos, etc.) nos equipamentos.

Os sistemas de aterramento estão presentes em todas instalações elétricas, seja por motivos operacionais (para servir de referência elétrica), proteção (aterramento de partes metálicas condutoras não energizadas), ou ambos. Tais sistemas são constituídos, essencialmente, por um ou mais eletrodos de aterramento, pela terra que os envolve e por condutores de ligação entre eletrodos ou entre o eletrodo e os equipamentos. Os eletrodos de aterramento são formados por condutores, hastes, fitas, chapas e tubos metálicos enterrados de forma que mantenham contato direto com o solo.

- $\quad$ NBR 7117 - Medição da Resistividade Elétrica do Solo pelo Modelo dos 4 Pontos: Procedimentos similares aos da norma IEEE Std 81,

- NBR 5410/2004 - Instalações Elétricas em Baixa Tensão (BT): Define 5 tipos de aterramento, em função da ligação da alimentação dos circuitos elétricos e do aterramento das massas;

- NFPA 70-2000 - National Electric Code (NEC): Equivalente americana da NBR 5410. O aterramento recomendado para QEE corresponde ao sistema tipo $1(\mathrm{TN}-\mathrm{S})$ da NBR 5410; 
- ANSI/C2-2007 - National Electric Safety Code (NESC): Fixa itens básicos para salvaguardar pessoas de danos ocasionados pela instalação, operação ou manutenção sistemas ou componentes elétricos;

- IEEE Std 142-1991 - Recommended Practice for Grounding of Industrial and Commercial Power Systems (Green Book): Apresenta recomendações e orientações para aterramento de sistemas, equipamentos e proteção contra descargas atmosféricas e estática;

- IEEE Std 1050-2004 Guide for Instrumentation and Control Equipment Grounding in Generation Stations: Guia desenvolvido para identificar métodos de aterramento de equipamentos de instrumentação e controle, para prover níveis adequados de proteção pessoal e equipamentos, e imunidade ao ruído elétrico em grandes estações de geração;

- ANSI/IEEE Std 81.1 - 1983 Guide for Measuring Earth Resistivity, Ground Impedance, and Earth Surface Potentials of Ground System: Este guia descreve e discute o estado da técnica de medir resistência e impedância de aterramento, resistividade elétrica do solo, gradientes de potencial produzidos por correntes injetadas no solo, e predizer os valores de resistência de aterramento e gradientes de potencial a partir de modelos em escala;

- IEC/TR 60479-4:2004 - Effects of current on human being and livestoke - Parts 1 to 4: Estas publicações enfatizam a apresentação dos aspectos medicos da corrente elétrica passando pelo corpo humano, servindo como base para o estabelecimento de requisitos de segurança sob o ponto de vista da engenharia para seres humanos e gado bovino.

\subsection{1 - Problemas típicos}

A seguir, apresentamos alguns dos problemas típicos de QEE devido à falta de adequação da fiação e aterramento dos sistemas elétricos. Alguns desses problemas podem ser detectados apenas com uma observação simples, daí a importância de conhecê-los. 
- Problemas com condutores e conectores -Uma má conexão (defeituosa, frouxa, ou apresentando resistência elevada) resultará em aquecimento excessivo com possível queima do isolamento;

- Perda do aterramento de segurança - Se o aterramento de segurança é perdido, uma falta entre um condutor de fase e a carcaça de um equipamento resulta em uma tensão de fase nas partes expostas do equipamento;

- Equipamento não aterrado - Sistemas isolados de terra são algumas vezes utilizados devido à necessidade de se obter um "terra limpo". O procedimento adequado para se utilizar um sistema isolado de terra deve ser buscado. Tais aplicações, na maioria das vezes, são perigosas e não resolvem problemas de ruído elétrico.

- Hastes ou malhas de aterramento adicionais: Hastes ou malhas de aterramento fazem parte do sistema de aterramento, conectadas onde todos os eletrodos de aterramento da edificação (aço estrutural, canalizações metálicas de água, etc.) estão todas interligadas. Hastes e malhas de aterramento devem ser ligadas entre si, visando reduzir a resistência total de aterramento. Aterramentos isolados podem ser empregados para equipamentos sensíveis, como descrito anteriormente. Entretanto, não dever ser empregados estes aterramentos isolados para estabelecer uma nova referência de terra para os equipamentos. Um problema muito importante de QEE com hastes de aterramento adicionais é que elas criam novos caminhos para o fluxo das correntes das descargas atmosféricas. Com as hastes de terra na entrada de serviço, boa parte das correntes das descargas atmosféricas fluem para o solo naquele ponto, e a elevação do potencial de terra ocorre igualmente em toda a instalação. Com hastes de aterramento adicionais, uma porção da corrente da descarga atmosférica fluirá pelos condutores da edificação para alcançar os aterramentos adicionais. Isto cria possíveis problemas de transitórios de tensão para os equipamentos e possíveis sobrecargas para os condutores.

- Laços de aterramento - Os laços de aterramento são um dos mais importantes problemas de aterramento em muitas instalações comerciais e industriais que possuem processamento de dados e equipamentos de 
comunicação. Se dois equipamentos estão aterrados por caminhos distintos e existe um cabo de comunicação entre eles, este terceiro caminho pode produzir potenciais ligeiramente diferentes entre os dois sistemas de aterramento, produzindo uma corrente circulante no cabo de comunicação mesmo que não exista um caminho completo. [05]

- Condutor de neutro insuficiente - Fontes de alimentação chaveada e iluminação fluorescentes, com reatores eletrônicos, estão se tornando cada vez mais comuns em edifícios comerciais. O grande conteúdo de terceiro harmônico presente nestas correntes de carga pode ter um impacto muito importante no dimensionamento do condutor de neutro para circuitos de alimentação.

Por fim, o sistema de aterramento deve ser capaz de no mínimo atender os seguintes objetivos:

1. Não deve existir correntes fluindo no sistema de aterramento em condições normais de operação.

2. Deve existir uma referência equipotencial para todos os dispositivos e locais do sistema elétrico.

3. Todas as carcaças dos equipamentos devem ser ligadas ao sistema de aterramento equipotencial, como meio impeditivo de tensões de toque.

\subsection{2 - Aterramento para sinal de referência}

Até aqui, muitos dos requisitos de aterramento descritos referem-se a aspectos de segurança para operação adequada de sistemas de proteção. No entanto, como visto no início deste capítulo, uma das funções do aterramento é o de fornecer um ponto de referência de sinal para equipamentos de comunicação e controle.

Em todos os sistemas eletro-eletrônicos é necessário se ter uma tensão de referência (ou um referencial). Dentro dos aparelhos existem várias tensões, como por exemplo as tensões das fontes de alimentação, as tensões dos geradores de corrente e/ou dos geradores de tensão e as tensões de sinal. Todas estas tensões devem estar correlacionadas entre si de 
uma forma preestabelecida. Para isto, é necessário se fazer um aterramento interno no aparelho, o qual fornecerá um referencial seguro para o funcionamento correto deste aparelho. Caso este aterramento não seja feito, podem ocorrer, oscilações internas, audíveis ou não, que prejudicam o aparelho. [41]

Os requisitos para o aterramento de sinal são diferentes daqueles para aterramento de segurança. O requisito mais importante de um aterramento de segurança é apresentar uma baixa impedância sobre uma larga faixa de freqüências, mais especificamente freqüências baixas.

Uma forma de fornecer um terra de referência de sinal para equipamentos sensíveis, efetivo é empregando uma malha de referência zero. Nesta técnica, emprega-se uma malha retangular de condutores de cobre com janelas de $60 \mathrm{~cm}$. A vantagem deste tipo de malha se evidencia quando uma parte do sistema de condutores está em ressonância em uma freqüência particular, sempre haverá outros caminhos que não estarão em ressonância devido aos múltiplos caminhos disponíveis para o fluxo de corrente.

Quando aplicado uma malha de referência de sinal, a carcaça de cada equipamento deve estar ligada a um sistema de aterramento (sistema em malha densa).

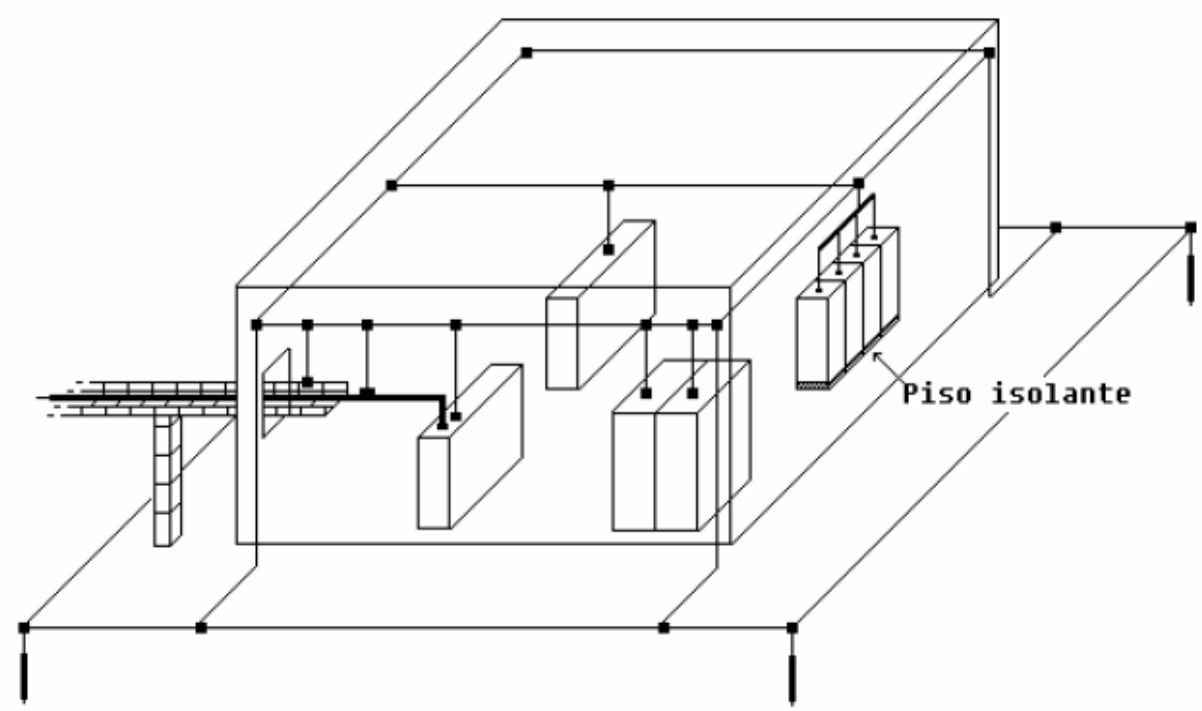

Figura 5.11: Vista geral de um sistema de equalização em malha densa [23] 


\section{ANTENAS E ATERRAMENTO}

Iniciou-se este estudo a partir das seguintes indagações: Afinal, uma antena pode puxar raios? Se eu colocar uma antena no alto de minha casa, sem qualquer tipo de proteção, estou correndo algum tipo de risco?

A partir daí, apresentou-se dados quanto à origem e formação das descargas atmosféricas, da forma como os corpos (metálicos ou não) se comportam sob a sombra de nuvens com sua base polarizada negativamente, da concentração de cargas e a busca do raio piloto por um caminho capaz de descarregar no solo seu excesso de cargas elétricas.

Foi mostrado que qualquer corpo sob a sombra que se destaque diante do relevo terá um acúmulo de cargas em seu topo (daí o perigo de se abrigar sob árvores durante tempestades!). Depois, foi mostrado as formas de descarga entre as nuvens e a terra, ou seja, descargas diretas, descargas indiretas e suas conseqüências.

Com base nestes dados pode-se agora refletir as questões levantadas anteriormente com mais propriedade.

\section{1 - O conceito de antena}

Uma antena é um condutor (ou sistema de condutores) que irradia ou recebe energia na forma de ondas eletromagnéticas. Ou seja, uma antena é um transdutor capaz de converter corrente alternada em ondas eletromagnéticas, e vice-versa.

Tanto uma antena transmissora quanto uma receptora têm as mesmas características. A esta propriedade dá-se o nome de reciprocidade. Ou seja, não há diferença nas suas propriedades tanto para transmitir quanto para receber os sinais, diferenciando-se apenas no seu aspecto construtivo.

Numa estação repetidora de TV a antena é o elemento responsável pela conversão da potência do transmissor em ondas eletromagnéticas e também fazê-las chegar até o seu receptor. Do outro lado do canal de comunicação, numa residência por exemplo, a antena é o elemento responsável por captar essas ondas eletromagnéticas e entregá-la ao aparelho de televisão ou rádio. Sua eficiência para concretizar esses dois trabalhos é fator determinante 
de como a estação "ouve" e será "ouvida" pelas residências. O objetivo da antena de TV é garantir o melhor sinal com o menor ruído possível.

Para cumprir isso ela deve ser colocada no ponto mais alto da residência de modo a receber a maior gama de sinais possível. Sendo a melhor forma de garantir seu sucesso seja posicionar a antena receptora num local que garanta uma "visada direta" para com a antena transmissora.

A antena transmissora acopla a energia presente no circuito de saída de rádio frequiência $(\mathrm{RF})$ do rádio transmissor ao espaço físico de forma a transformar a corrente alternada presente no circuito de saída em ondas eletromagnéticas irradiadas. Desse modo, a antena é construída com o objetivo de tornar este acoplamento o mais eficiente possível.

Por sua vez, a antena receptora tem a função de converter as ondas eletromagnéticas irradiadas pela antena transmissora em sinais elétricos. Quando a onda eletromagnética atinge uma antena receptora a energia eletromagnética presente na onda gera uma tensão na antena receptora que faz com que uma corrente possa fluir pelo circuito receptor. A antena receptora deve ser desenhada para ter a máxima eficiência na frequiência da transmissora que deseja sintonizar.

Desse modo, a antena transmissora costuma ser instalada no alto dos morros e colinas para que sua área de cobertura seja a mais extensa possível. Por isso, no intuito de "driblar" possíveis obstáculos, deve-se expor a antena receptora à "sombra" da antena transmissora.

\section{2 - Tipos de antena}

As antenas podem ser subdivididas de acordo com seu padrão de irradiação. $O$ padrão de irradiação é a forma como a energia eletromagnética é distribuída no espaço. Desse modo, pode-se dividir as antenas em três tipos principais:

- Antena direcional;

- Antena semi-direcional;

- Antena isotrópica. 
Antenas direcionais são antenas que transmitem os sinais em uma única direção, com ângulo de irradiação bastante fechado, ficando aproximadamente entre 3 e 20 graus, cobrindo uma área bastante restrita. São exemplos de antenas direcionais as parabólicas, as yagis e as helicoidais.

Antenas semi-direcionais ou setoriais são antenas que transmitem os sinais também em uma única direção, porém com um ângulo de irradiação bastante aberto, ficando aproximadamente entre 30 e 180 graus, cobrindo uma área bastante extensa, o modelo básico é o painel setorial.

A antena isotópica irradia uniformemente em todas as direções, como se a antena estivesse concentrada dentro de uma esfera, irradiando para toda a superfície da mesma e ao seu redor com intensidade igual. No entanto, ela é um modelo teórico usado como referência para ensaios com os outros tipos de antenas.
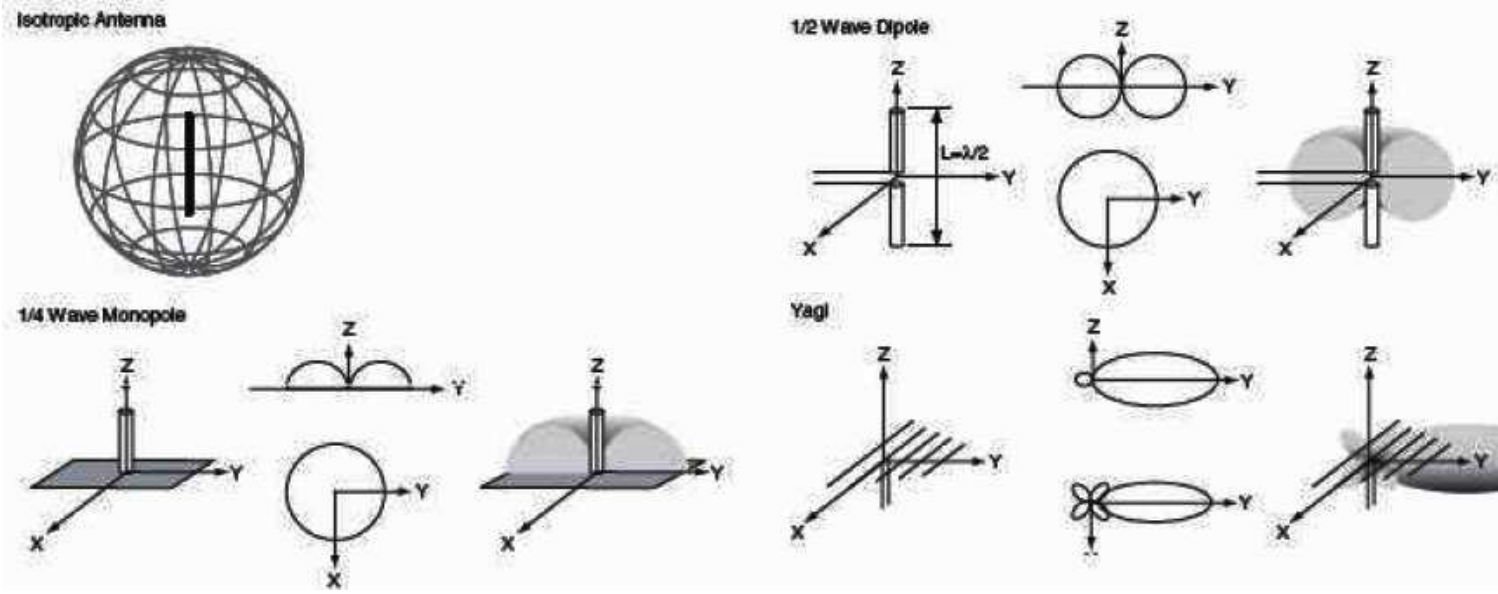

Figura 6.01 Padrões de irradiação das antenas [42]

Para a análise da possibilidade de atração dos raios por antenas de TV, este estudo concentrou-se em dois tipos de antenas: a antena modelo Yagi e a Parabólica. Os motivos para tal escolha foram a popularidade destas com relação aos demais modelos, facilidade de montagem e empregabilidade.

A partir daí, apresentou-se uma breve descrição dos aspectos construtivos e funcionais das antenas, seguido pela discussão dos riscos reais a que as antenas estão sujeitas e, conseqüentemente, as residências e seus freqüentadores. Daí, conclui-se falando da melhor forma de proteção contra descargas atmosféricas para cada antena. 


\subsection{1 - Antenas Yagi-Uda}

Foi desenvolvida pelo Dr. Hidetsugo Yagi, professor da Universidade de Vohoku no Japão, e por seu colega e assistente Dr. Shintaru Uda. Apesar da antena ter se popularizado com o nome Yagi, o próprio Dr. Yagi a chamou de antena Yagi-Uda em reconhecimento ao seu colega e assistente.

O conceito básico da antena se baseia em um dipolo ressonante alimentado com um ou mais elementos parasitários. O elemento irradiante é o dipolo (ou elemento alimentado), possuindo meio comprimento de onda elétrico da frequência pretendida. O refletor é o maior elemento parasitário, normalmente 5\% maior que o elemento irradiante, situando-se "atrás" do irradiante, e o diretor é 5\% menor que o dipolo. Esse arranjo dá direcionalidade para antena, da qual um dipolo comum carece. Os elementos parasíticos re-emitem um sinal na fase pouco diferente da do dipolo. Assim, o sinal é reforçado em uma direção e cancelado em outra, melhorando-o. Isso resulta numa melhor relação frente-costa para a antena Yagi-Uda. O maior ganho da antena Yagi-Uda está no plano da posição dos elementos, perpendicular ao dipolo, na direção do refletor ao diretor. Observação: um dipolo será ressonante quando seu comprimento elétrico for de meio comprimento de onda da frequência aplicada no ponto de alimentação. [43]

A antena Yagi pode ser implementada nas faixas de VHF e UHF, opera segundo a orientação mecânica dos seus elementos em polarização linear horizontal ou linear vertical.

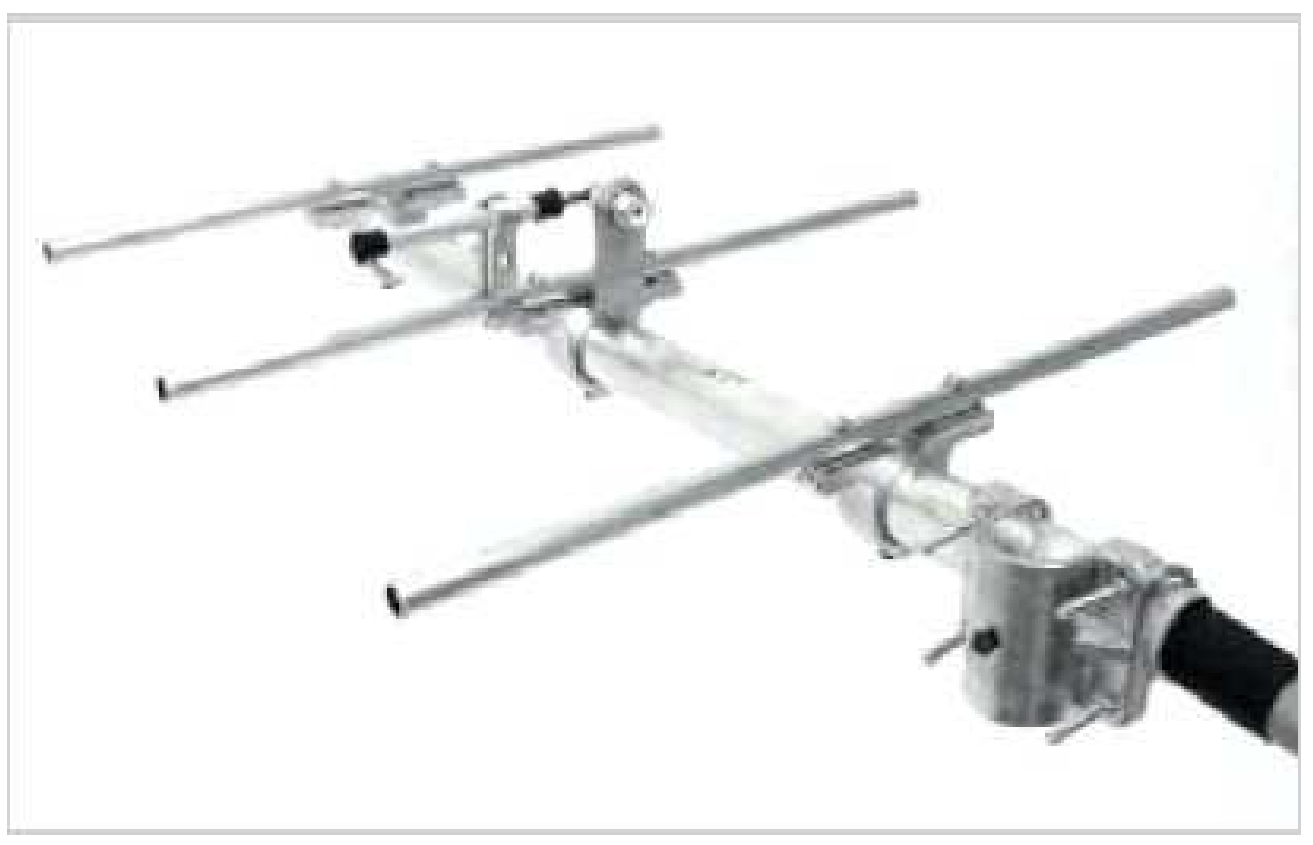

Figura 6.02: Exemplo de antena Yagi [42] 
A polarização é uma característica importante para uma antena e diz respeito a orientação dos fluxos dos campos elétrico e magnético gerados pela antena. A recepção melhor ocorre quando a antena receptora e a antena transmissora possuem a mesma polarização, caso-contrário parte da energia transmitida é perdida.

\subsection{2 - Antenas Parabólicas}

Para o estabelecimento de enlaces ponto a ponto em aplicações de repetição de sinais ou até mesmo retransmissão, a exigência de antenas com elevado ganho nas faixas de UHF e Microondas tornam as antenas parabólicas a solução mais indicada.

Em aplicações de Radiodifusão, as parabólicas mais utilizadas recaem na categoria de antenas tipo "focal point" onde o alimentador ou "feeder" está situado geometricamente no ponto focal da parábola configurada pelo refletor.

A foto da Figura 6.03 ilustra uma antena parabólica deste tipo para utilização como receptora de TV, onde o refletor é do tipo sólido. Em UHF, dado o maior comprimento de onda e dimensão do refletor parabólico, utilizam-se telas ou grades como superfície refletora.

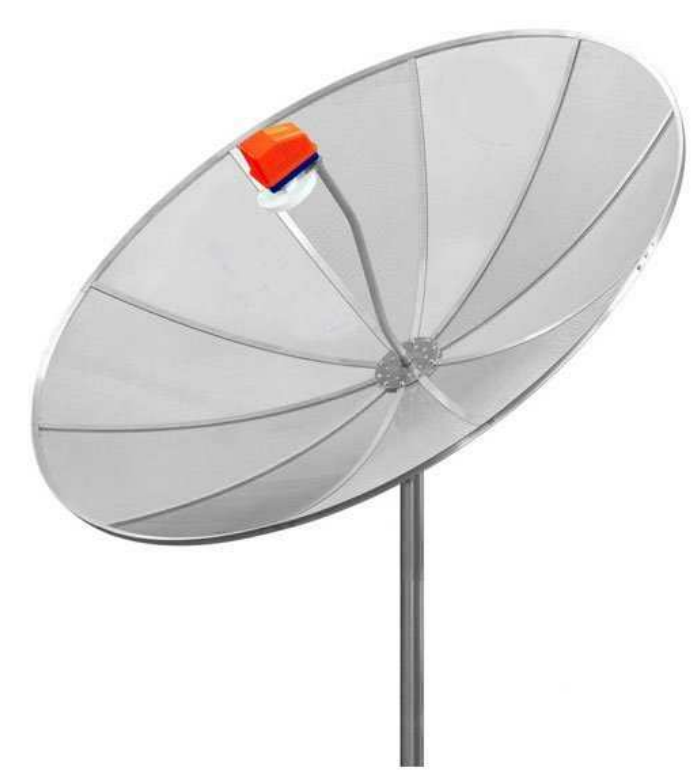

Figura 6.03: Exemplo de antena parabólica [42] 


\section{3 - Tipos de riscos}

Como visto no capítulo 4, qualquer corpo metálico elevado sobre uma estrutura qualquer deve ser considerado como um captor natural. Além disso, deve estar presente nos cálculos sua influência em relação às perturbações causadas pelos raios quando do projeto de um sistema de proteção contra descargas atmosféricas.

Devido a configuração potencial das nuvens de tempestades (base eletricamente negativa e topo eletricamente positivo), quando uma destas paira sobre uma residência com antena externa instalada acima desta, haverá uma concentração de cargas sobre e em volta da antena. Nesta configuração, a antena poderá contribuir para o surgimento de uma descarga direta sobre ela, destruindo-a por completo.

Como as antenas parabólicas costumam ser mais baixas que as residências, a princípio elas estariam protegidas contra descargas diretas. No entanto, para descargas indiretas, tanto antenas Yagi-Uda quanto antenas parabólicas estão sujeitas aos mesmos efeitos.

Um sistema de recepção de sinal de TV é composto pela antena - responsável pela captação do sinal na atmosfera, pelo cabo de comunicação - que liga o elemento "vivo" da antena ao receptor e o receptor de TV - responsável pela entrega do sinal no aparelho de TV.

Ao acontecer uma descarga atmosférica nas proximidades das antenas, são geradas em seus corpos tensões e correntes induzidas que na busca por um caminho ao terra podem ser conduzidas pelo cabo de comunicação ao interior da residência. Como os cabos terminam no receptor, e este último na TV, caso a TV não esteja aterrada, estas ondas impulsivas de tensão e corrente percorrerão a malha elétrica até achar um caminho para a terra.

Uma analogia a este comportamento pode ser feita com o Movimento dos Sem Terra (MST). Os raios são como os membros do MST, cujo maior sonho é ter seu "pedaço de terra". Para consegui-lo o raio não se intimidará de procurar por todos os caminhos possíveis. No caso de uma sobretensão no sistema elétrico residencial devido a uma descarga direta, todos os aparelhos ligados à tomada estarão sujeitos a esta sobtensão, gerando situações de transferência de carga para a terra por toque (tensão de toque). 


\section{4 - O aterramento da antena}

Como visto, apesar de pequena, a possibilidade de uma antena ser atingida direta ou indiretamente por um raio é real. Por possuírem corpos metálicos, possuírem "pontas" e devido a sua localização, as antenas assumem características similares ao captor de um SPDA, e como este, devem ser aterradas.

O melhor jeito de se fazê-lo seria, ainda na fase de projeto da residência, solicitar ao engenheiro prever em seus cálculos as condições necessárias para usar a malha metálica da estrutura da residência como malha de aterramento. Desse modo, esta malha metálica se comportaria da mesma forma que uma gaiola de Faraday diante de uma descarga atmosférica, conforme visto no capítulo 4. Além disso, deve-se prever locais de ancoragem ligando a carcaça (ou haste) da antena à malha da construção. Uma observação importante: só se pode usar a malha metálica da estrutura como malha de aterramento se esta tiver sido prevista para funcionar como tal ainda na faze de projeto. Caso contrário, na ocorrência de uma descarga sobre a estrutura, a corrente não escoaria para a terra.

Quando a alternativa anterior não pode ser atendida, deve-se atender a uma série requisitos para garantir o máximo de segurança à residência e seus habitantes. Primeiramente, deve-se verificar a existência de uma barra equipotencial na entrada da residência. Caso não exista, deve-se corrigir esta falta, garantindo que todos os volumes com carcaças metálicas estejam devidamente ligados ao PEN. No lado de fora da construção, considerando o tipo de terreno e sua geografia, deve-se fazer um aterramento em forma de anel e ligando este ao PEN.

Especificamente no caso das antenas, deve-se puxar um cabo de descida ligando a haste da antena a um eletrodo e este ultimo ao anel de aterramento. No caso de parabólicas, a blindagem dos cabos coaxiais deve ser aterrado em ambas as extremidades. $\mathrm{Na}$ extremidade ligada na antena, deve haver uma ligação física da blindagem à carcaça aterrada. Na extremidade do receptor, este deve estar ligado ao sistema PEN da residência e o cabo ligado a ele.

Caso já exista um sistema de proteção contra descargas atmosféricas na residência, deve-se garantir que os cabos de descida desse sistema de proteção sejam ligados ao sistema de aterramento da casa, para garantir que as sobrecorrentes ali induzidas possam rapidamente escoar para a terra. 


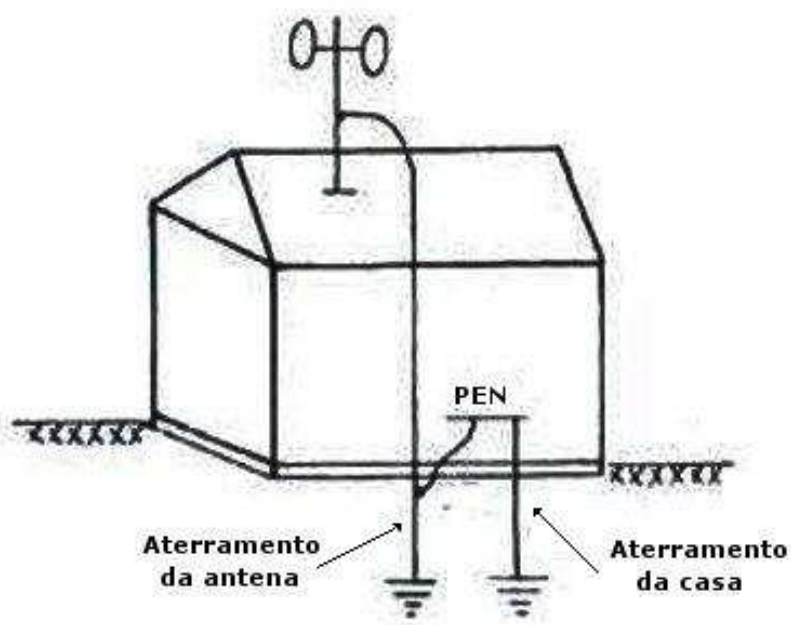

Figura 6.03: Mastro da antena aterrado e ligado ao PEN da residência [04]

$\mathrm{O}$ aterramento da antena de TV traz dois benefícios: proteção pessoal e dos equipamentos e, melhoria do sinal captado (aterramento de referência). Todos estes procedimentos têm um custo relativamente elevado. No entanto, conforme dito no capítulo 3, este custo é desprezível quando comparados aos possíveis estragos decorrentes de descargas atmosféricas sobre antenas de TV.

O artigo 810 do NEC ANSI/NFPA 70 (Código Elétrico Americano), fornece informações precisas a respeito do aterramento apropriado do mastro e da estrutura de suporte, aterramento do cabo de entrada para uma unidade de descarga da antena (centelhador a gás por exemplo), tamanho dos condutores de aterramento, localização d unidade de descarga da antena, conexão aos eletrodos de aterramento e os requerimentos do eletrodo de aterramento. Na figura abaixo há um exemplo destas diretrizes:

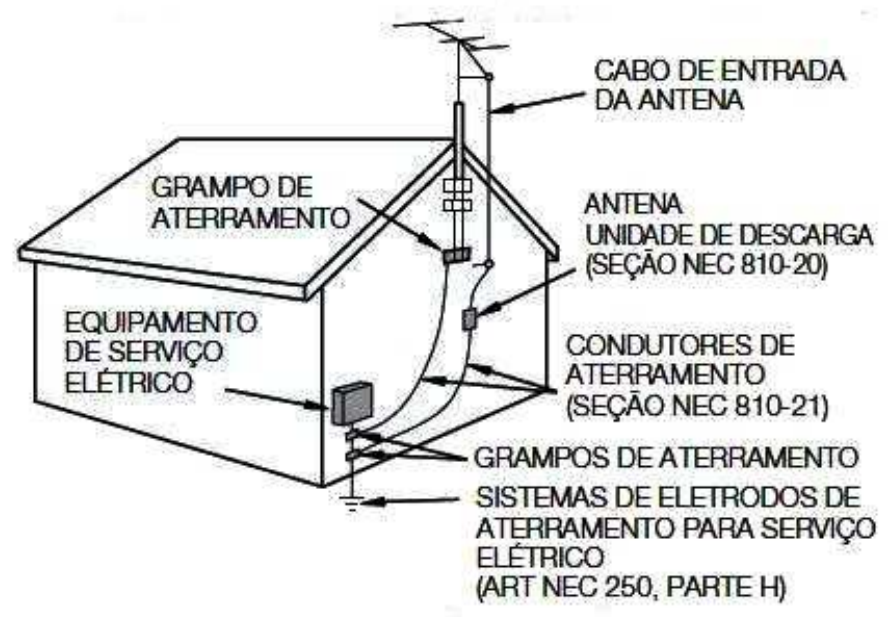

Figura 6.04: Exemplo de aterramento de antena pelo NEC [37] 


\section{5 - Vistorias em condomínios}

Como boa parte das edificações de Brasília é composta por prédios, é de fundamental importância que se vistorie esporadicamente as instalações do SPDA (se existir). Se o prédio possuir um SPDA mas não souber se este está dentro das normas, deve-se executar uma vistoria técnica, feita por um engenheiro eletricista, de acordo com a Norma NBR 5419/2005.

Quando o SPDA é instalado, o edifício recebe três documentos do engenheiro responsável:

- Uma ART (renovada a cada manutenção);

- O projeto do sistema;

- Um relatório técnico da instalação.

O SPDA deve proteger a estrutura do edifício contra descargas elétricas, bem como as pessoas que nele circulam. Os aparelhos eletrônicos não são protegidos pelo SPDA, (para isso, devemos ter um bom sistema de equipotencialização e aterramento). Quando equipamentos eletro-eletrônicos são destruídos significa que ou a queda do raio induziu uma sobrecorrente no sistema de distribuição de energia e, trafegando pela malha de alimentação, entrou no sistema elétrico da edificação e, na tentativa de chegar ao Terra saiu queimando tudo que estava conectado às tomadas; ou o raio induziu uma sobrecorrente numa antena de TV (não aterrada) e desceu pelo cabo de TV até o aparelho ou aparelhos ligados no sistema.

Alguns condomínios utilizam o sistema de aterramento através da malha metálica da própria estrutura, achando que dessa forma estarão seguros. Na verdade isto só pode ser feito se tiver sido previsto no projeto de construção. Caso contrário, estará colocando em risco os moradores do edifício que poderão sofrer uma ddp de passo.

O sistema de pára-raios deve ser checado anualmente para garantir o perfeito funcionamento do sistema.

Esta vistoria deve ser feita por engenheiro/empresa especializada em medições ôhmicas, deve verificar as condições do terreno, a resistência de aterramento, as conexões mecânicas (na busca por folgas ou interrupções), as condições das hastes, limpeza no 
cabeamento e nos captores, reposição de peças estragadas, etc. Deve-se ainda verificar se a caixa d'agua está devidamente aterrada.

Após todos estes procedimentos, o engenheiro emite um atestado conclusivo da vistoria, apontando todos os pontos críticos, inclusive necessidades de troca de equipamentos defeituosos.

O síndico deve ter todas estas informações em mãos. Caso ocorra algum acidente, se o síndico dispuser da ART atualizada, da vistoria assinada e com todos os equipamentos de segurança validados para evitar problemas relativos. 


\section{CONCLUSÕES}

A descarga atmosférica é um fenômeno da natureza imprevisível e aleatório, tanto em relação à suas características elétricas (intensidade de corrente, tempo de duração, etc.), como aos efeitos destrutivos decorrentes de sua incidência sobre as edificações.

Os sistemas de proteção implantados de acordo com a norma NBR 5419/2005, visam a proteção da estrutura das edificações contra as descargas que atinjam de forma direta, não sendo função de um SPDA proteger equipamentos eletro-eletrônicos localizados no interior das edificações. Para esse fim, a NBR 5410/2004 dá orientações detalhadas que garantem uma maior proteção contra os efeitos nocivos das descargas.

Normalmente colocadas acima das edificações para melhor captação dos sinais, as antenas de TV possuem todas as características de um captor (de acordo com a Norma 5419/2005, todo corpo metálico colocado na cobertura de uma edificação deve ser considerado como um captor natural), e o que poderia ser considerado como apenas uma simples montagem de fim de semana pode vir a se tornar uma brecha para ocorrências desagradáveis.

Verificou-se que apesar de constar na norma, e das penalidades à que os condomínios verticais estão sujeitos na falta de um SPDA, a mesma fiscalização não é encontrada (ou mesmo praticada) nas instalações de BT residenciais. Daí, mesmo que a edificação não esteja dentro de uma área considerada perigosa, ou pelos resultados dos cálculos de risco cheque a conclusão de não haver necessidade de um SPDA, considerando as características meteorológicas de nosso país, concluímos que é aconselhável o aterramento e equipotencialização do sistema de TV.

$\mathrm{O}$ aterramento não se restringe à proteção. Um bom aterramento e equipotencialização dos equipamentos, pode filtrar o sinal de TV de ruídos e blindar os equipamentos contra interferências eletromagnéticas.

Esperamos que este estudo possa trazer esclarecimento à população quanto a importância do aterramento para a edificação, não se resumindo apenas à proteção de equipamentos de informática.

Como estudo preliminar, este trabalho sobre o aterramento de antenas de TV em edificações residenciais revelou a não - prática regular de aterramento desses dispositivos de comunicações largamente instalados nas moradias. 
Sujeitas a diversos bombardeios de fenômenos eletromagnéticos, as antenas são receptores de interferências e bons guias desses sinais para os equipamentos internos às edificações. Assim, pelo montante de equipamentos nas residências, pelas proximidades com os usuários quando de uma descarga atmosférica, as antenas merecem análise mais criteriosa com respeito ao seu aterramento e equipotencialização na instalação elétrica como um todo.

Sugestões, portanto, para novas pesquisas devem contemplar:

1. Definição da qualidade de antena de TV e percentual de aterramento em determinado espaço amostral;

2. Tipo e qualidade do aterramento;

3. Equipotencialização efetiva na edificação e a inserção de antena nesse sistema;

4. Estatística de acidentes envolvendo descargas atmosféricas e antenas de TV;

5. Legislação e o estado-de-arte sobre o tema. 


\section{REFERÊNCIAS BIBLIOGRÁFICAS}

\section{LIVROS}

[01] VISACRO FILHO, Silvério., Aterramentos Elétricos, São Paulo: Editora Artliber, 2005

[02] KINDERMANN, Geraldo. Descargas Atmosféricas, Florianópolis, Edição do autor, $3^{\mathrm{a}}$ ed., 2002;

[03] CREDER, H. Instalações Elétricas, Rio de Janeiro: Editora LTC, 12ª ed., 1991;

[04] LEITE, D.; Leite, C. M. Proteção contra Descargas Atmosféricas, São Paulo: MM Editora, 1993;

[05] TELLÓ, Marcos (Org.), Guilherme A. D. Dias ... [ET AL.]. Aterramento Elétrico Impulsivo em baixa e alta frequiência, Porto Alegre: Editora ediPUCRS, 2007;

[06] VISACRO FILHO, Silvério, Descargas Atmosféricas: uma abordagem de engenharia, São Paulo, Artliber Editora, 2006;

[07] UMAN, Martin, All About Lightning, Academic Press, 1987;

[08] HART, William C; MALONE, Edgar W. Lightning And Lightning Protection, Published by Don White Consultants, Inc. 1979;

[09] SANCHES, Durval. Interferência Eletromagnética, Rio de Janeiro: Editora Interciência, 2003

[10] E M BAZELYAN, E. M.; RAIZER, YU. P.,Lightning Physics and Lightning Protection, Institute of Physics Publishing Bristol and Philadelphia, 2000

\section{TESES E DISSERTAÇÕES}

[11] COUTINHO, Fernando N.; ALTOÉ, Cássio A., Levantamento de Estruturas que necessitam de SPDA na UnB e Análise de seus Efetivos Sistemas de Proteção Atmosféricas, Projeto Final de Graduação em Engenharia Elétrica, Departamento de Engenharia Elétrica, Orientador: Prof. Alcides Leandro da Silva, Universidade de Brasília, Brasília - DF, 2003. 
[12] SILVA, Noemi S. A; JÚNIOR, Carlos Alberto F. M., Minimização de Riscos de Choque Elétrico e Danos a Equipamentos por meio de Aterramento Adequado, Projeto Final de Graduação em Engenharia Elétrica, Departamento de Engenharia Elétrica, Orientador: Prof. Alcides Leandro da Silva, Universidade de Brasília, Brasília - DF, 2004.

[13] NOLETO, Sérgio Ricardo Carvalho, As Estruturas Metálicas das Edificações como Sistemas de Proteção Contra Descargas, Projeto Final de Graduação em Engenharia Elétrica, Departamento de Engenharia Elétrica, Orientador: Prof. Alcides Leandro da Silva, Universidade de Brasília, Brasília - DF, 2006;

[14] GUEDES, D. G. Modelagem matemática de correntes na torre da estação Morro do Cachimbo (Brasil). 2003. 262 p. (INPE-10549-TDI/938). Tese (Doutorado em Geofísica Espacial) - INPE, São José dos Campos. 2003.

[15] PEREIRA, João Batista José. Modelagem de Incertezas em Sistemas de Aterramento Elétricos. Tese de Doutorado em Engenharia Elétrica, Departamento de Engenharia Elétrica, Universidade de Brasília, Brasília - DF, 2008 .

[16] PAUlinO, José Osvaldo Saldanha,. Proteção Elétrica de Sistemas de Comunicações. Tese de Doutorado em Engenharia Elétrica - Campinas, 1996

\section{ARTIGOS}

[17] DIENDORFER, Gerhard. Lightning Location Systems (LLS). IX International Symposium on Lightning Protection. 26th-30th November 2007 - Foz do Iguaçu, Brazil;

[18] BERGER, Gérard. Lightning-caused accidents and injuries to humans. IX International Symposium on Lightning Protection. 26th-30th November 2007 Foz do Iguaçu, Brazil;

[19] BERGER, Gérard, Lightning-caused accidents and injuries to humans, IX International Symposium on Lightning Protection, 2007;

[20] IBAÑEZ, M. M.; MENDES JUNIOR, O.; DOMINGUES, M. O.; STEPHANY, S. Representação de campos de descarga elétrica atmosférica nuvem-solo na ferramenta opendx. In: SICINPE - 2006., (campo ausente ou vazio: 'date') São José dos Campos. (campo ausente ou vazio: 'booktitle') 2006. p. 34 p. (INPE- 
14009-PRE/9184). http://urlib.net/sid.inpe.br/mtc-m16@80/2006/08.14.14.34. Acesso em: 05 jun. 2009.

[21] BAZELYAN, E.M; RAIZER, Yu P. Lightning Physics and Lightning protection,

Published by Institute of Physics Publishing, wholly owned by The Institute of Physics, London, 2000;

[22] CAPELLI, Alexandre, Aterramento Elétrico

[23] PAULINO, J. O. Saldanha,. Proteção elétrica de estações de telecomunicações, Campinas, 2006

[42] Curso de Antenas Trans Tell - Capítulo 2: Tipos de antenas e suas propriedades

\section{NORMAS E WEBSITES}

[24] ABNT NBR 5419/2005: Proteção de estruturas contra Descargas Atmosféricas, Associação Brasileira de Normas Técnicas, 2005;

[25] ABNT NBR 5410/2004: Instalações Elétricas de Baixa Tensão, Associação Brasileira de Normas Técnicas, 2005;

[26] MTE: NR 10 (2006), Instalações e Serviços em Eletricidade. Manual de Segurança e Medicina no Trabalho, Ministério do Trabalho e Emprego, 2005;

[27] NFPA 780 A2004-ROC: Lightning Protection;

[28] IEC 62305-SER Ed. 1.0 b:2007: Protection against lightning;

[29] BS 6651/1999 - Code of practice for protection of structures against lightning;

[30] VDE 0185/1998 - Protection against lightning electromagnetic impulse (LEMP);

[31] Eletric Ground: www.eletricground.com.br. Visitado em Março/2009.

[32] Portal Lumière: http://www.portallumiere.com.br. Visitado em Maio/2009

[33] Engenharia no dia-a-dia: http://engenharianodiaadia.blogspot.com. Visitado em Junho/2009

[34] Faculdade de Física UFPA: http://www.ufpa.br/ccen/fisica/aplicada/inicial.htm. Visitado em Maio/2009

[35] A garrafa de Leiden: http://www.feiradeciencias.com.br/sala11/11_24.asp. Visitado em Junho/2009

[36] ELAT/INPE: http://www.inpe.br/webelat/homepage/. Visitado em Maio/2009

[37] Manual Televisor LCD SHARP LC-52R64B 
[38] Fórum under-linux: http://under-linux.org/b517-aconteceu-por-falta-de-aterramento. Visitado em Janeiro/2009

[39] Revista Saber Eletrônica: http://www.sabereletronica.com.br/. Edição Dez/2008.

[40] Site do Radioamador: http://www.radioamador.com. Visitado em Junho/2009

[41] Site Jorge Knirsch: http://www.byknirsch.com.br/artigos.shtml. Visitado em Junho/2009

[43] Guiadohardware.net: http://www.guiadohardware.net/tutoriais/alcance-antenasconectores-potencia/pagina3.html. Visitado em Julho/2009 
ANEXO A - Classificação das estruturas quanto ao nível de proteção

\begin{tabular}{|c|c|c|c|}
\hline $\begin{array}{l}\text { CLASSIFICAÇĀO DAS } \\
\text { ESTRUTURAS }\end{array}$ & ESTRUTURAS TIPICAS & EFEITOS DOS RAIOS & \begin{tabular}{|l|} 
NIVEL. DE \\
PROTECÄO \\
\end{tabular} \\
\hline \multirow[t]{7}{*}{$\begin{array}{l}\mathbf{1}^{\circ} \text { ESTUTURAS COMUNS: } \\
\text { as preocupaçoes devem ser com } \\
\text { os efeitos na própria estrutura. }\end{array}$} & Residências & $\begin{array}{l}\text { Perfuraçăo da isolação de } \\
\text { instalaçấo elétrica, inceandio e } \\
\text { danos materiais. Danos } \\
\text { normalmente limitados a objetos } \\
\text { no ponto de impacto ou no } \\
\text { caminho do raio. }\end{array}$ & III \\
\hline & Fazendas & $\begin{array}{l}\text { Risco primário de incêndio e } \\
\text { tensőes de passo perigosas. Risco } \\
\text { secundário devido à interrupçăo de } \\
\text { energia, e risco de vida a animais } \\
\text { devido à perda de controle } \\
\text { eletrônico de ventilaçá. } \\
\text { suprimento de alimento etc. }\end{array}$ & III ou IV \\
\hline & $\begin{array}{l}\text { Teatros, escolas, igrejas, lojas } \\
\text { de departamentos, areas } \\
\text { esportivas. }\end{array}$ & $\begin{array}{l}\text { Danos às instalaçóes elétricas, } \\
\text { possibilidade de pânico, falha do } \\
\text { sistema de alarme contra incêndio. }\end{array}$ & II \\
\hline & $\begin{array}{l}\text { Bancos, companhia de seguro, } \\
\text { companhis comercial, etc. }\end{array}$ & $\begin{array}{l}\text { Consequências adicionais na } \\
\text { ligação com a perda de } \\
\text { comunicaçao, falha dos } \\
\text { computadores e perda de dados. }\end{array}$ & II \\
\hline & $\begin{array}{l}\text { Hospitais, casas de repouso e } \\
\text { prisoes }\end{array}$ & $\begin{array}{l}\text { Efeitos adicionais as pessoas em } \\
\text { tratamento intensivo, dificuldade } \\
\text { de resgate de pessoas imobilizadas. }\end{array}$ & II \\
\hline & Indústrias & $\begin{array}{l}\text { Efeitos adicionais na fabricaçăo, } \\
\text { variando de danos pequenos at } \\
\text { prejuízos inaceitaveis e perda da } \\
\text { produção. }\end{array}$ & III \\
\hline & Museus, locais arqueológicos & Perda de tesouros insubstituive is & II \\
\hline $\begin{array}{l}2^{\circ} \text { ESTRUTURAS COM } \\
\text { DANOS CONFINADOS: as } \\
\text { preocupaçoes devem ser com os } \\
\text { efeitos na própria estrutura e } \\
\text { com a atividade executada. } \\
\text { intemamente. }\end{array}$ & $\begin{array}{l}\text { Telecomunicaçá, usinas de } \\
\text { força, industria com risco de } \\
\text { incêndio }\end{array}$ & $\begin{array}{l}\text { Inaceitável perda de serviços ao } \\
\text { público por pequeno ou longo } \\
\text { período de tempo. Perigo às } \\
\text { imediaçoes devido a incendios. }\end{array}$ & 1 \\
\hline $\begin{array}{l}3^{\circ} \text { ESTRUTURAS COM } \\
\text { PERIGO AOS ARREDORES: } \\
\text { as preocupaçoes devem ser com } \\
\text { os efeitos anteriores, mais com } \\
\text { os efeitos nas estruturas } \\
\text { adjacentes ou de certa regiăo, }\end{array}$ & $\begin{array}{l}\text { Refinarias, depósitos de } \\
\text { combustiveis, fábricas de } \\
\text { inflamáveis, fábricas de } \\
\text { muniçâa }\end{array}$ & $\begin{array}{l}\text { Consequéncias de incêndio e } \\
\text { explosăo da instalaçăo para os } \\
\text { arredores. }\end{array}$ & 1 \\
\hline $\begin{array}{l}4^{\circ} \text { ESTRUTURAS COM } \\
\text { DANOS AO MEIO } \\
\text { AMBIENTE: as preocupaçóes } \\
\text { devem ser com os efeitos } \\
\text { temporários ou permanentes no } \\
\text { meio ambiente, }\end{array}$ & $\begin{array}{l}\text { Instalaçoes químicas, } \\
\text { laboratórios, instalaçoes } \\
\text { nucleares, bioquímicas, etc. }\end{array}$ & $\begin{array}{l}\text { Fogo e mal funcionamento da } \\
\text { fábrica com consequencias } \\
\text { perigosas ao local e ao meio } \\
\text { ambiente como um todo. }\end{array}$ & I \\
\hline
\end{tabular}


ANEXO B: FOTOS DE ACIDENTES COM RAIOS

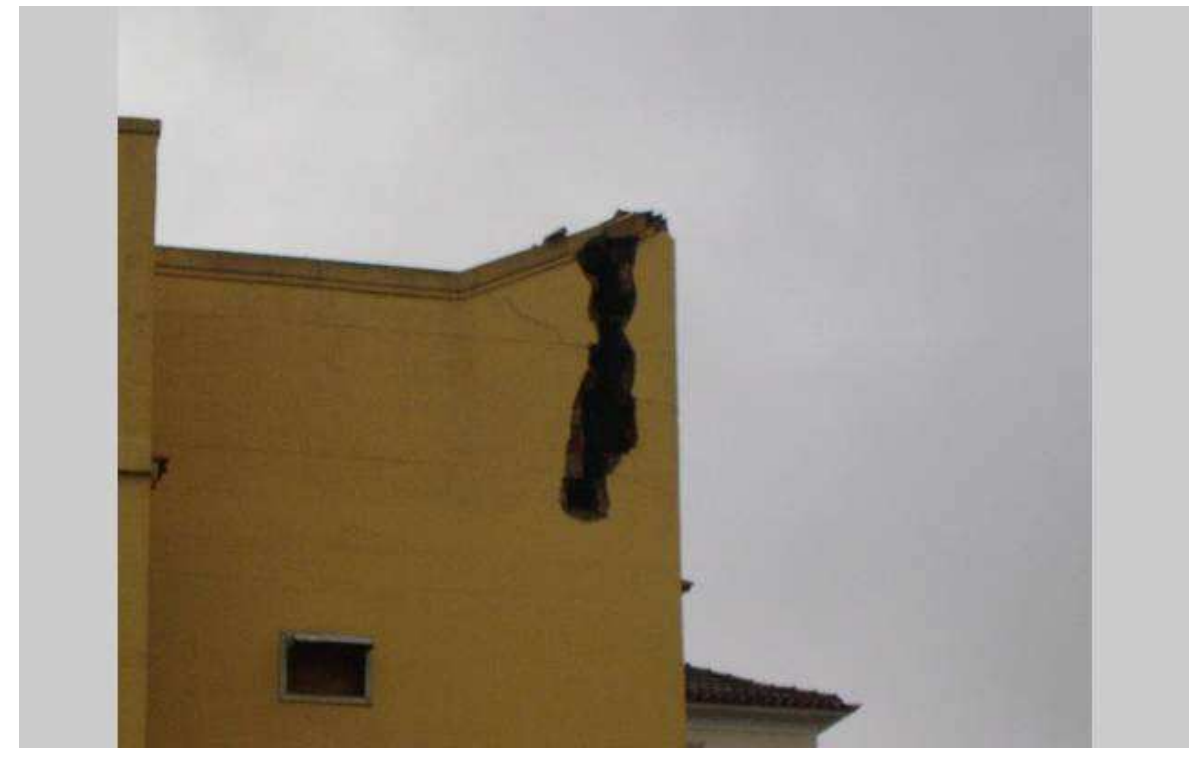

Descarga Direta sobre Edificação não protegida 01

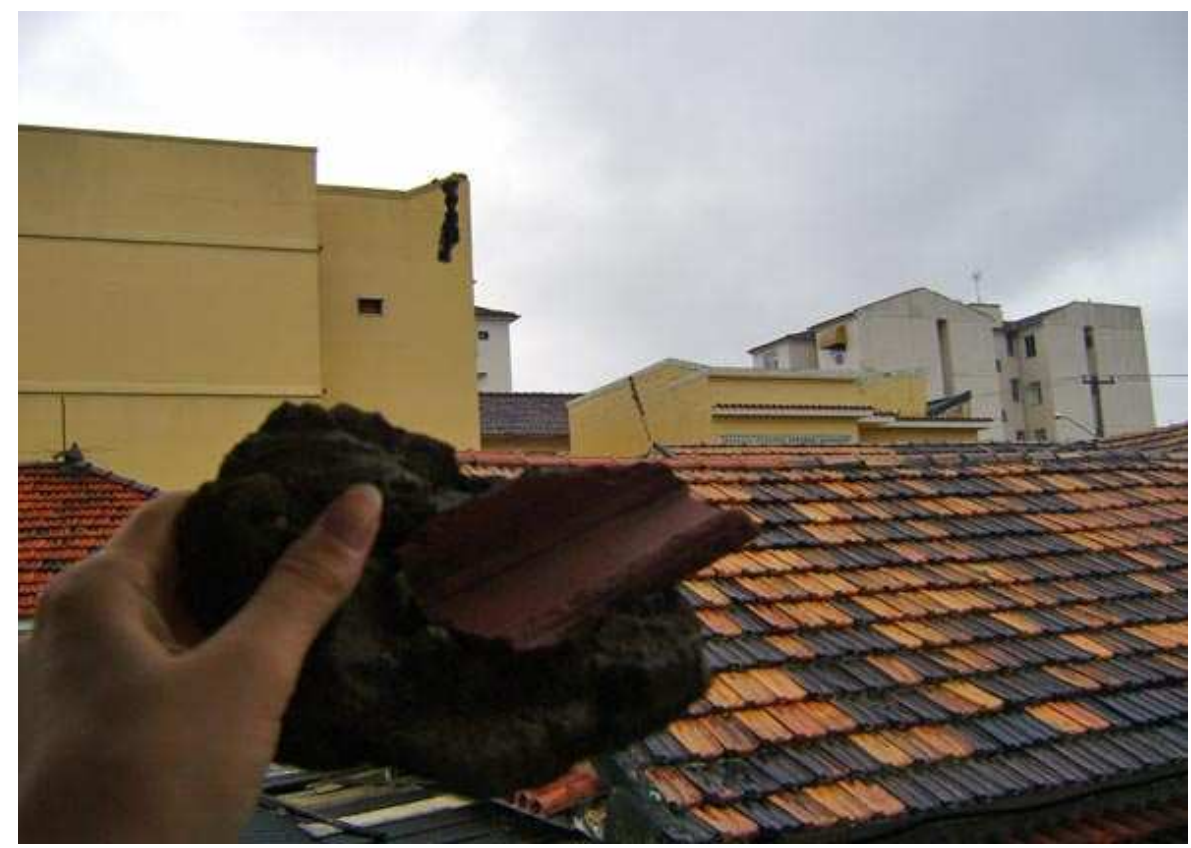

Descarga Direta sobre Edificação não protegida 02 